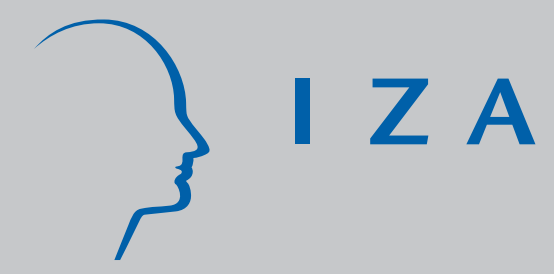

IZA DP No. 4037

Financial Globalization and Economic Policies

M. Ayhan Kose

Eswar Prasad

Kenneth Rogoff

Shang-J in Wei

February 2009 


\title{
Financial Globalization and Economic Policies
}

\author{
M. Ayhan Kose \\ International Monetary Fund \\ Eswar Prasad \\ Cornell University and IZA \\ Kenneth Rogoff \\ Harvard University \\ Shang-Jin Wei \\ Columbia University
}

\section{Discussion Paper No. 4037 \\ February 2009}

\author{
IZA \\ P.O. Box 7240 \\ 53072 Bonn \\ Germany \\ Phone: +49-228-3894-0 \\ Fax: +49-228-3894-180 \\ E-mail: iza@iza.org
}

Any opinions expressed here are those of the author(s) and not those of IZA. Research published in this series may include views on policy, but the institute itself takes no institutional policy positions.

The Institute for the Study of Labor (IZA) in Bonn is a local and virtual international research center and a place of communication between science, politics and business. IZA is an independent nonprofit organization supported by Deutsche Post Foundation. The center is associated with the University of Bonn and offers a stimulating research environment through its international network, workshops and conferences, data service, project support, research visits and doctoral program. IZA engages in (i) original and internationally competitive research in all fields of labor economics, (ii) development of policy concepts, and (iii) dissemination of research results and concepts to the interested public.

IZA Discussion Papers often represent preliminary work and are circulated to encourage discussion. Citation of such a paper should account for its provisional character. A revised version may be available directly from the author. 


\section{ABSTRACT}

\section{Financial Globalization and Economic Policies}

We review the large literature on various economic policies that could help developing economies effectively manage the process of financial globalization. Our central findings indicate that policies promoting financial sector development, institutional quality and trade openness appear to help developing countries derive the benefits of globalization. Similarly, sound macroeconomic policies are an important prerequisite for ensuring that financial integration is beneficial. However, our analysis also suggests that the relationship between financial integration and economic policies is a complex one and that there are unavoidable tensions inherent in evaluating the risks and benefits associated with financial globalization. In light of these tensions, structural and macroeconomic policies often need to be tailored to take into account country specific circumstances to improve the risk-benefit tradeoffs of financial integration. Ultimately, it is essential to see financial integration not just as an isolated policy goal but as part of a broader package of reforms and supportive macroeconomic policies.

JEL Classification: F02, F21, F36, F4

Keywords: financial globalization, emerging markets, capital flows, capital account liberalization

Corresponding author:

Eswar Prasad

440 Warren Hall

Department of Applied Economics and Management

Cornell University

Ithaca, NY 14853

USA

E-mail: eswar.prasad@cornell.edu

\footnotetext{
* This paper is prepared for the Handbook of Development Economics, edited by Dani Rodrik and Mark R. Rosenzweig. We would like to thank Stijn Claessens, Marco Terrones, and our discussant, Dani Rodrik, for their detailed suggestions. We also thank conference participants for providing helpful comments at the Handbook Preconference. Dionysis Kaltis and Yusuke Tateno provided excellent research assistance. The views expressed in this paper are solely those of the authors and do not necessarily reflect those of the IMF or IMF policy.
} 


\section{Introduction}

Financial globalization has been one of the most intensely debated topics of our times. Some academic economists view increasing capital account liberalization and unfettered capital flows as a serious impediment to global financial stability (e.g., Rodrik, 1998; Bhagwati, 1998; Stiglitz, 2002), leading to calls for capital controls and the imposition of frictions such as "Tobin taxes" on international asset trade. In contrast, others argue that increased openness to capital flows has, by and large, proven essential for countries aiming to upgrade from lower to middle income status, while significantly enhancing stability among industrialized countries (e.g., Fischer, 1998; Summers, 2000).

Financial globalization is clearly a matter of considerable policy relevance, especially with major economies like China and India recently taking steps to open up their capital accounts. A number of developing countries are still in the early stages of financial globalization facing numerous ongoing policy decisions about the timing and pace of further integration. The stakes for such policy decisions are high because financial globalization is often blamed for the string of damaging economic crises that rocked a number of emerging markets in the late 1980s in Latin America and in the 1990s in Mexico and a handful of Asian countries. The market turmoil and resulting bankruptcies prompted a rash of finger pointing by those who suggested that developing countries had dismantled capital controls too hastily-leaving themselves vulnerable to the harsh dictates of rapid capital movements and market herd effects.

Moreover, financial globalization is also a fascinating topic to study for researchers of development economics not only because of its compelling policy relevance, but because of the enormous variation of approaches and experiences across countries. Differences in speed and approach to financial globalization have often been driven as much by philosophy, regional fads and political circumstances as by economic factors. Hence, cross-country studies of the effects of financial integration can potentially exploit a wide array of natural variation in experiences.

There has been an explosion of research in this area over the past two decades. Most of this work is of relatively recent vintage, since the latest wave of financial globalization got started in earnest only in the mid-1980s. However, the research program on financial globalization has proceeded along a number of disparate paths, with the results from some of these strands seeming at odds with each other. ${ }^{1}$ The inconclusive nature of the debate about the merits of financial globalization has reflected itself on the design of economic policies aiming to manage the process of financial integration. While consensus on the outcomes of financial globalization and the complex policy issues surrounding them may be too much to hope for, some clarity on what theory and data do tell us - and what they do not tell us - is important for informing the ongoing debate.

\footnotetext{
${ }^{1}$ For some other recent surveys on financial globalization, see Eichengreen (2001), Prasad et al. (2003), Kose et al. (2006), Mishkin (2006), Henry (2007) and Obstfeld (2007).
} 
The objective of this chapter is to review the large literature focusing on various economic policies that could help developing economies effectively manage the process of financial globalization. In particular, we try to identify structural and macroeconomic policies that can improve the growth and stability benefits of financial globalization for developing countries.

In section II, we present some basic stylized facts about the temporal evolution of financial flows. Studying policy issues surrounding financial globalization necessarily requires an analysis of the associated measurement issues and this section starts with a brief summary of those. We then analyze how the volume and composition of financial flows have changed over time. The volume of flows has risen substantially during the past two decades. Not only has there been a much greater volume of flows among advanced countries over this period but there has also been a surge in flows between advanced and developing countries. There are important differences across country groups in the relative importance of different types of inflows, although there has been a broad shift away from debt financing towards FDI and equity flows in all groups.

In section III, we survey the theoretical arguments and empirical evidence about the macroeconomic outcomes associated with financial globalization. This section largely relies on the framework put forward by Kose et al. (2006). We focus on the implications of financial integration for the dynamics of growth, volatility and risk-sharing patterns. Although our overall take is that the literature is still inconclusive, we argue that newer approaches that attempt to focus more on the indirect effects of financial globalization hold considerable promise. At the same time, we find that there is scant empirical support to underpin the more polemic claims of those who argue that capital account liberalizations (as opposed to, say, inappropriately rigid exchange rate regimes) are the root problem behind most developing country financial crises of the past two decades (Bhagwati, 1998; Stiglitz, 2002).

The survey of the rapidly evolving literature on the merits of financial globalization also reveals that newer approaches depart from the standard neoclassical framework that largely guided the earlier studies. In particular, the earlier literature viewed the key benefit of financial globalization as arising from long-term net flows of capital from advanced to developing economies. Since the former group of countries is capital rich while the latter is relatively capital poor, this should generate higher growth in developing economies and welfare gains for both groups. Perhaps not surprisingly, in light of the corresponding literature on growth in closed economies, this literature often found conflicting results.

The fundamental conceptual point that guides our interpretation of the newer literature is that the main benefits to successful financial globalization are probably catalytic and indirect. The benefits are not simply, or even primarily, the result of enhanced access to financing for domestic investment. We document that there is modest but increasing evidence that financial openness can in many circumstances promote development of the domestic financial sector, impose discipline on macroeconomic policies, generate efficiency gains among domestic firms by exposing them to competition from foreign entrants, and unleash forces that result in better 
public and corporate governance. That is, it can generate significant indirect or "collateral" benefits which, in quantitative terms, are likely to be the most important sources of enhanced growth and stability for a country engaged in financial globalization.

The notion that financial globalization mainly influences growth through indirect channels has potentially important implications for the design of economic policies towards financial globalization. In particular, if one can identify which reform priorities are the key ones for a particular country, then one can design an approach to liberalization that could generate specific benefits while minimizing the associated risks. This also provides a broader analytical framework within which one can incorporate country-specific features and initial conditions into the design of appropriate capital account liberalization programs.

There is also a growing literature studying a range of supporting conditions associated with structural and policy related factors (thresholds) that appear to play an important role in the relationship between growth and financial openness. This literature argues that economic policies designed to foster these necessary supporting conditions are key in deriving better outcomes from financial globalization. Sections IV, V and VI provide an overview of this literature and attempts to draw some policy messages. In particular, we focus on an economy's structural features - the extent of financial sector development, institutional quality, and trade integration - and its macroeconomic policy framework. For each of these factors, we review the underlying theoretical arguments and survey the relevant empirical evidence.

Our findings suggest that economic policies promoting financial sector development, institutional quality and trade openness are important not only in their own right, but in helping developing countries derive the benefits of globalization. Similarly, sound macroeconomic policies appear to be an important prerequisite for ensuring that financial integration is beneficial for these countries. We also find that excessive reliance on fixed exchange rate regimes has probably been one of the major contributing factors to financial crises in emerging market countries over the past fifteen years. Moving to more flexible exchange rate regimes is therefore likely to considerably alleviate some of the risks countries must endure as they become more financially integrated (for countries that are not financially integrated, fixed exchange rate regimes may be a perfectly good choice). In addition, countries that consistently face problems associated with government debt are more likely to benefit from financial globalization if their governments simultaneously take policy measures to avoid an excessive buildup of debt.

Capital has recently been flowing "uphill” from poor to rich countries. More interestingly, among non-industrial countries there appears to be a positive correlation between a country's current account surplus and its growth rate. Section VII studies the implications of these somewhat perverse empirical observations for economic policies in light of some recent studies. We argue that these findings are broadly consistent with the policy implications stemming from our framework of collateral benefits and threshold factors. 
The next section analyzes the macroeconomic implications of capital controls. Since sudden stops and reversals of inflows of foreign capital have precipitated costly crises in some emerging market countries, capital controls have regained some of their luster, among certain academics and policymakers, as effective policy tools to dampen the potentially adverse effects of financial integration. The evidence on the macroeconomic implications of capital controls is at best mixed while some recent studies indicate that controls appear to lead to various costs at the micro level.

In section IX, we consider some potential approaches to financial globalization in light of the findings of some recent studies. These studies reflect the notion that financial globalization carries a short-run cost — one that must inevitably be paid if a developing country, which typically has weak institutions and a fragile financial sector, wants to move on to a high-growth path. Given that the collateral benefits perspective argues financial globalization is potentially a useful catalyst for improving domestic institutions and financial sector, it appears that developing countries face a very complex policy problem with respect to financial integration. We argue that the collateral benefits perspective could be helpful in resolving this problem.

The final section of the paper provides some concluding remarks and lays out a number of key research questions for future research.

\section{Financial Globalization: Measurement and Trends}

Defining the concept of financial globalization requires us to confront a multitude of measurement problems. ${ }^{2}$ Resolution of these problems is key in analyzing the implications of financial globalization as well as in designing effective policy measures to utilize its gains. After providing a brief discussion of these measurement issues, this section documents the evolution of the degree of financial globalization using a couple of well-known metrics and then summarizes the factors driving the process of financial globalization.

\section{II.1. How to Measure Financial Integration?}

\section{Capital Controls (De Jure Measures)}

Most of the earlier empirical studies use measures of legal restrictions (capital controls) on crossborder capital flows to assess the degree of financial openness. Such capital controls come in many varieties--controls on inflows versus those on outflows, quantity versus price controls, restrictions on foreign equity holdings, etc. Based on information from the IMF's Annual Report on Exchange Arrangements and Exchange Restrictions (AREAER), the early literature on capital account liberalization often employed a binary (0/1) measure of capital account openness. Some

\footnotetext{
${ }^{2}$ Financial globalization refers to rising global linkages through cross-border financial flows. Financial integration refers to an individual country's linkages to international capital markets. In this chapter, we use these terms interchangeably.
} 
researchers have used a "share" measure, reflecting the fraction of years in the sample in which a country's capital account was open. Other authors have taken the detailed information in the AREAER publications to construct finer measures of capital account restrictiveness. ${ }^{3}$

Although there has been substantial progress in developing finer and more sophisticated measures of capital controls, all of these measures suffer from a variety of similar shortcomings. First, they do not accurately reflect the degree of openness of the capital account because they are partially based on various restrictions associated with foreign exchange transactions that may not necessarily impede capital flows. Second, they do not capture the degree of enforcement of capital controls (or the effectiveness of that enforcement), which can change over time even if the legal restrictions themselves remain unchanged. ${ }^{4}$ Third, and most importantly, these measures do not always reflect the actual degree of integration of an economy into international capital markets, as we have already noted. As another example, China, despite its extensive regime of capital controls, has not been able to stop inflows of speculative capital in recent years (see Prasad and Wei, 2007). ${ }^{5}$

\section{Financial Flows/Stocks (De Facto Measures)}

Quantity-based measures of integration based on actual flows appear to be the best available measure of a country's de facto integration with global financial markets. ${ }^{6}$ Should one measure integration using gross flows (the sum of total inflows and total outflows) or net flows (the difference between inflows and outflows)? Although the choice depends on the precise question one is interested in, gross flows in general provide a less volatile and more sensible picture of integration as it has the advantage of capturing two-way flows. However, annual gross flows tend to be volatile and prone to measurement error. To mitigate these problems, it is preferable to

\footnotetext{
${ }^{3}$ Share measures have been created by Grilli and Milesi-Ferretti (1995), Rodrik (1998), and Klein and Olivei (2006). Finer measures of openness based on the AREAER have been developed by Quinn (1997, 2003), Miniane (2004), Chinn and Ito (2005), Mody and Murshid (2005) and Edwards (2005). Edison and Warnock (2003) construct measures of capital account restrictions related to just equity flows. Some recent studies consider more disaggregated measures based on the AREAER descriptions (see Schindler, 2008). Bekaert and Harvey (2000) and Henry (2000a) compile dates of equity market liberalizations for developing countries.

${ }^{4}$ Edwards (2005) notes that binary measures suggest similar levels of capital account restrictiveness in Chile, Mexico and Brazil during the period 1992-1994. In fact, Mexico had a rather open capital account, Brazil employed a complex set of controls on capital flows, and there were some controls on short-term flows in Chile.

${ }^{5}$ A further complication is that, despite the extensive coverage of the IMF's annual AREAER publication, there could be other regulations that effectively act as capital controls but are not counted as controls. For an extensive discussion of these issues, see Kose et al. (2006).

${ }^{6}$ Other quantity based measures of integration include price-based measures of asset market integration and saving-investment correlations (see Karolyi and Stulz, 2003; Obstfeld and Taylor, 2004). Related to the price-based approach, researchers also employ various interest parity conditions (see Frankel, 1992; and Edison and others, 2002). There are, however, serious problems in using these measures as they are difficult to operationalize and interpret for an extended period of time and for a large group of countries.
} 
use the sum of gross stocks of foreign assets and liabilities as a ratio to GDP. This preserves the spirit of measuring de facto integration and obviates many of the problems associated with flow data. Moreover, for some purposes--particularly the analysis of risk sharing--stock measures are more appropriate.

De facto measures of financial integration based on gross flows/stocks also have some drawbacks. For example, Collins (2007) argues that de facto indicators are likely to be endogenous in growth regressions, making it difficult to pin down causal effects. As we discuss later, de jure measures also have a strong element of endogeneity to them, in addition to other deficiencies. While there is important information in both the de jure and de facto measures of financial integration, de facto measures provide a better picture of the extent of a country's integration into global financial markets and, for many empirical applications, this measure is more suitable.

\section{II.2. Evolution of Financial Globalization: Some Basic Stylized Facts}

Figure II. 1 displays the absolute level of integration of different country groups into global financial markets, calculated as the sum of gross international financial assets and liabilities. ${ }^{7}$ There has been an obvious surge in financial globalization especially since the mid-1980s. ${ }^{8}$ While the level of integration is clearly highest for the advanced economies, emerging market countries have accounted for the bulk of the integration experienced by developing countries. The gross stocks of assets and liabilities of this group has risen by more than fivefold and has been on average an order of magnitude larger than that of other developing countries during the past two decades.

Figure II. 2 compares the evolution of de jure integration based on the IMF's binary capital account restrictiveness measure, averaged across all countries in each group, and corresponding group averages of the de facto financial openness measure (stock of international financial assets and liabilities expressed as a ratio to GDP). By both measures, advanced economies have become substantially integrated into global financial markets. For emerging market economies, average de jure openness has not changed much based on the IMF measure, but de facto integration has increased sharply over the last two decades. For other developing economies, de jure openness on average rose sharply over the last decade, to a level higher than that for emerging market economies, but the de facto measure has stayed flat over this period. This figure highlights the different informational content in the two types of integration measures and

\footnotetext{
${ }^{7}$ The de facto measures of financial integration that we use here draw upon the pioneering work of Lane and Milesi-Ferretti (2006), who have constructed an extensive dataset of gross liabilities and assets for 145 countries covering the period 1970-2004.

${ }^{8}$ A much earlier wave of financial globalization, which took place between 1880 and 1914, has been analyzed by Bordo, Taylor and Williamson (2003), Obstfeld and Taylor (2004), and Mauro, Sussman and Yafeh (2006).
} 
the importance of taking these differences into account in analyses of the effects of financial globalization.

Figure II. 3 presents the evolution of the composition of total foreign assets and liabilities for different groups of countries. Among the advanced economies, the biggest increase has been in the share of portfolio equity during the past two decades. The share of debt in gross stocks of foreign assets and liabilities of emerging market economies has declined from 75 percent to 50 percent during the same period while the share of FDI and portfolio equity has risen from a total of 13 percent to 40 percent. The share of portfolio equity has been rather small in the total stocks of other developing countries. Accumulation of official international reserves has recently accounted for a significant portion of the increase in gross foreign assets of developing economies. In general, these findings suggest that there has been a broad shift away from debt financing towards FDI and equity flows in all groups and some of these patterns are stronger when one looks at gross private inflows (see Kose et al., 2006). ${ }^{9}$

\section{II.3. Factors Driving Financial Globalization}

The surge in financial flows to developing countries, as well as the shifts in the composition of these flows, can be broken down into "pull" and "push" factors (Calvo, Leiderman and Reinhart, 1994). These are related to, respectively, (i) policies and other developments in developing countries and (ii) changes in global financial markets. The first category includes factors such as policies with respect to capital and trade accounts, institutional quality and governance practices and policies towards privatization of state-owned companies. For example, there has been a substantial increase in the fraction of countries with liberalized capital and trade accounts since the mid-1980s (Figure II.4). Moreover, more financially integrated economies are the ones that have registered the largest increase in the degree of trade openness over the same period (Figure II.5). ${ }^{10}$ As we discuss later in the chapter, some economic policies associated with these pull factors can affect the macroeconomic outcomes of financial globalization through their impact on the volume and composition of financial flows. The second category includes the growing importance of depositary receipts and cross-listings and the emergence of institutional investors as key players driving international capital flows to emerging markets (Prasad et al., 2003).

\section{Macroeconomic Implications of Financial Globalization}

We begin with a brief introduction to the theoretical and empirical links between financial globalization and macroeconomic outcomes in this section. In particular, we focus on the effects

\footnotetext{
${ }^{9}$ While debt financing remains the most important source of inflows for advanced economies, FDI now accounts for almost half of total inflows into developing economies. Equity flows have become quite important for emerging markets, accounting for almost 12 percent of inflows, while this category still remains virtually non-existent for other developing economies, reflecting their underdeveloped stock markets.

${ }^{10}$ Akin and Kose (2008) document a variety of stylized facts about the evolution of trade and financial linkages, their underlying determinants and the changing nature of growth dynamics around the world.
} 
of financial globalization on growth, volatility and patterns of risk-sharing. Since financial globalization has often been associated with the recent emerging market financial crises, we also analyze its impact on crises, which can be considered as special cases of volatility.

\section{III.1. Economic Growth}

\section{III.1.1. Theory}

Based on the standard one-sector neoclassical growth model, the traditional (direct) theoretical channel through which financial globalization affects economic growth is the augmentation of capital. In other words, the standard theory predicts that financial globalization should lead to flows of capital from capital-rich economies to capital-poor economies since, in the latter, the returns to capital should be higher. In theory, these financial flows should complement limited domestic saving in capital-poor economies and, by reducing the cost of capital, allow for increased investment. ${ }^{11}$ Certain types of financial flows could also generate technology spillovers and serve as a conduit for imbibing managerial and other forms of organizational expertise from more advanced economies.

Newer analyses emphasize the importance of indirect channels arguing that it is not just the direct financial flows, but the collateral benefits of these flows, that drives the growth benefits of financial globalization (see Kose et al., 2006). These indirect channels include development of the domestic financial sector, improvements in institutions (defined broadly to include governance, the rule of law etc.) and better macroeconomic policies.

These indirect theoretical channels are the subject of recent work. For example, Levine (2005) and Mishkin $(2006,2008)$ discuss the impact of financial integration on financial sector development. Stulz (2005) focuses on institutional quality and concludes that globalization weakens certain agency problems by reducing the cost of outside finance, thereby creating incentives for firms that use more external finance to improve their governance. Gourinchas and Jeanne (2005) show that financial integration can impose discipline on macroeconomic policies by improving the benefits of good policies and catalyzing political support for reforms while Bartolini and Drazen (1997) argue that, in exposing itself to such costs through increased financial openness, a country may signal its commitment to better macroeconomic policies.

We could continue at considerable length about how financial globalization matters in theory, and will indeed keep introducing further ideas throughout the paper. However, what makes the debate on financial globalization fascinating is that several prominent economists question

\footnotetext{
${ }^{11}$ Henry (2007) argues that, even in the context of the basic neoclassical model, the financing channel should imply only a temporary, rather than permanent, pickup in growth from financial integration. It is not clear, however, how important this nuance is likely to be empirically in studies that look at growth experiences over periods of just 2-3 decades.
} 
whether, in practice, the effects are positive at all. Most of these economists base their arguments on the theory of the second best and the potential presence of other distortions stemming from the trade policy regime, macroeconomic policies, labor markets, and information asymmetries. For example, if certain industries are protected by trade barriers, international capital could flow into these sectors to exploit the benefits of protection in domestic markets and result in welfare losses and sub-optimal growth (Brecher and Diaz-Alejandro, 1977). Information asymmetries stemming from a lack of transparency in financial institutions could lead to inefficient allocation of financial flows, generate maturity mismatches, and result in costly crises (Stiglitz, 2004).

The concern that financial globalization can sometimes spin off negative side effects in highlydistorted developing economies is a legitimate one. Indeed, as we shall see, in light of the ambiguity of theoretical findings, the critical question regarding policy in this entire literature is whether empirical evidence can guide us on why financial globalization seems to have clearly positive effects in some cases, whereas it appears to be counterproductive in others.

\section{III.1.2. Empirical Evidence}

\section{Evidence on Direct Channels}

On the surface, there seems to be a positive association between embracing financial globalization and economic growth. For example, emerging market economies have, as a group, experienced far higher cumulative growth since 1970 than other developing countries or even industrial countries (Figure III.1). Excluding China and India from the list of emerging markets makes the performance of this group look less spectacular, although it is still better than that of the group of other developing countries.

12

To further illustrate the relationship between economic growth and financial openness, Figure III.2A (left panel) presents a scatter plot of the average growth rate of real per capita GDP against the average level of de facto financial openness over the past two decades. There is no systematic relationship between these variables. There is a weak positive association between average GDP growth and the change in the financial openness measure (Figure III.2B, left panel), consistent with the notion that economies that integrated into global financial markets grew faster. But once other growth determinants are controlled for, even this relationship vanishes (Figure III.2B, right panel).

\footnotetext{
${ }^{12}$ The rapid growth in emerging economies over the past two decades have led to speculations about a possible shift in the center of global growth fuelling questions about the implications of increased international linkages for the North-South growth dynamics. Akin and Kose (2007) examine these issues and provide empirical evidence about the changing nature of growth linkages across the Northern and Southern economies.
} 
The message of these figures is consistent with the inconclusive findings from the large part of the literature on the benefits of financial globalization based on cross-country growth regressions. While some of these studies conclude that there are growth benefits associated with international financial integration, the majority of them tend to find no effect or a mixed effect for developing countries. ${ }^{13}$ This once again confirms that if financial integration has a positive effect on growth, it is apparently not robust, especially once the usual determinants of growth are controlled for.

Why do different studies focusing on direct channels reach such diverse conclusions about the importance of financial integration in affecting long-run economic performance? Empirical studies using finer de jure measures of capital account openness appear to reach more positive results about the impact of financial integration on economic growth. ${ }^{14}$ In studies that use both de jure and de facto measures, specifications where capital account openness is measured using de facto measures tend to lend more support for the potential growth enhancing effects of financial integration than those employing de jure measures. There are other reasons why the results differ markedly across studies - the sample period, country coverage and choice of empirical methodology all make a big difference.

Moreover, depending on the types of financial flows considered, existing studies report vastly different results about the growth benefits of financial integration. Flows that have equity-like features - i.e., FDI and portfolio equity flows - are not only presumed to be more stable and less prone to reversals, but are also believed to bring with them some additional theoretical benefits of financial globalization such as transfers of managerial and technological expertise. In contrast, the procyclical and highly volatile nature of debt flows, especially short-term bank loans, can magnify the adverse impact of negative shocks on economic growth.

Although the aggregate growth benefits of FDI flows are hard to document, a reassessment of micro channels for technological spillovers from FDI inflows has begun to turn up more positive evidence of such spillovers. For example, direct evidence on the role of horizontal spillovers-productivity spillovers from foreign firms to domestic firms in the same sector--in transmitting the productivity benefits of FDI remains inconclusive. However, foreign firms have incentives to

\footnotetext{
${ }^{13}$ Endogeneity between financial integration and growth remains a potentially problematic issue in studies that find a positive association between these variables. Some authors have attempted to deal with this problem by using lagged measures of financial integration and GMM techniques in panel regressions. However, this problem may ultimately be intractable in macroeconomic data; looking at more disaggregated data may be one way out.

${ }^{14}$ For example, in a much-cited study, Rodrik (1998) finds that capital account liberalization has no significant effect on economic growth. His analysis is based on a very coarse binary measure of capital controls. Employing a finer and more informative version of the same de jure openness measure, Quinn and Toyoda (2006) document a positive association between capital account liberalization and economic growth.
} 
transfer knowledge to their local suppliers and customers, implying that productivity spillovers from FDI may occur through "vertical" linkages (see Javorcik, 2004).

The rising importance of portfolio equity flows to emerging markets has spurred a rapidlyexpanding literature that examines the growth effects of equity market liberalizations. Equity market liberalizations appear to improve economic performance, with an across the board increase in the growth rates of all major macro aggregates (Figure III.3). Most papers in this literature report significant positive effects of equity market liberalizations on growth. ${ }^{15}$ However, whether these estimated growth effects (in macroeconomic data) could be picking up the effects of other factors-especially other reforms that tend to accompany these liberalizations - remains an open question.

On the other hand, the body of microeconomic evidence (using industry- and firm-level data) supporting the macro evidence of the benefits of equity liberalizations is growing. Some of these papers also document the empirical relevance of various theoretical channels that link equity market liberalization to economic growth - including through increases in investment and total factor productivity growth (see Chari and Henry, 2004, 2005; Mitton, 2006). ${ }^{16}$

The empirical literature is fairly decisive about debt flows worsening the benefit-risk tradeoff related to inflows. In particular, there is a systematic empirical link between exposure to shortterm debt and the likelihood (and severity) of financial crises. One reason could be that countries with unfavorable conditions are forced to rely more on short-term external debt denominated in foreign currencies as their main source of foreign capital (Eichengreen, Hausmann, and Panizza, 2006). ${ }^{17}$

The summary so far suggests that there is no robust empirical evidence indicating that financial integration results in growth benefits through direct channels emphasized by the standard theory. Another empirical challenge facing the standard theory is about the direction (and actual volumes) of flows from capital-rich economies to capital-poor ones. In theory, capital should flow from relatively capital-rich countries (typically the advanced economies) to relatively capital-poor economies (typically the emerging markets and other developing economies) in order to equate marginal products of capital across countries. In fact, in recent years, capital has been flowing "uphill"- from the developing economies to the advanced economies. We will

\footnotetext{
${ }^{15}$ Bekaert, Harvey and Lundblad (2005) conclude that equity market liberalizations increase long-term GDP growth by about 1 percentage point, a remarkably strong effect. There is also evidence, consistent with the predictions of international asset pricing models, that stock market liberalizations reduce the cost of capital and boost investment growth. For evidence on the first point, see Stulz (1999a, 1999b), Bekaert and Harvey (2000), Henry (2000a), and Kim and Singal (2000). On the latter, see Henry (2000b) and Alfaro and Hammel (2006).

${ }^{16}$ Henry (2007) provides a detailed survey of this literature.

${ }^{17}$ For a survey of the empirical literature on the risks associated with short-term debt, see Berg, Borenzstein and Pattillo (2004).
} 
discuss the implications of this observation in detail later in the chapter. We now turn to the summary of the empirical literature focusing on the indirect channels and collateral benefits stemming from these channels.

\section{Indirect Channels}

The indirect channels studied in empirical studies include financial sector development, institutional quality and macroeconomic policies. Figures III.4A-III.4C present some simple unconditional correlations indicating that there could be some links between these channels and the extent of financial integration. During the recent period of financial globalization (19852004), financial openness is positively correlated with measures of financial development and institutional quality, and negatively correlated with log inflation. Its correlation with the government budget deficit is, however, essentially zero.

Recent empirical research provides some preliminary evidence that financial openness can promote development of the domestic financial sector, catalyze forces that result in better public and corporate governance, and impose discipline on macroeconomic policies. For example, work based on a variety of techniques supports the notion that increased foreign bank presence raises competition and leads to a decline in both bank overhead costs and profits. ${ }^{18}$ As for equity markets, the overwhelming theoretical presumption is that foreign entry increases efficiency yet the evidence is more mixed. While event studies suggest that stock markets become larger and more liquid after equity market liberalizations in a number of countries (Levine and Zervos, 1998), cross-country regressions indicate that financial openness contributes to equity market development only once at least a moderate level of legal and institutional development has been attained (Chinn and Ito, 2006). ${ }^{19}$

The empirical evidence on financial globalization and institutional quality, while still sparse, does seem to indicate that financial globalization has helped some countries in improving certain institutional features. For example, some countries have adjusted their corporate governance structures in response to demands from international investors (Cornelius and Kogut, 2003) ${ }^{20}$ In addition, reforms to institutions take place mostly after financial integration and that there appears to be a substantial improvement in the measures of law and order between partial and full liberalization (Kaminsky and Schmukler, 2003).

\footnotetext{
${ }^{18}$ See Claessens, Demirguc-Kunt, and Huizinga (2001), Levine (2001), Claessens and Laeven (2004), Clarke, Cull, Martinez Peria, and Sanchez (2003), Goldberg (2008) and Schmukler (2004). However, see Levy-Yeyati and Micco (2007) for a contrarian view based on a sample of Latin American economies.

${ }^{19}$ Baltagi et. al. (2007) documents that financial openness has a positive impact on the development of local financial markets in countries with low levels of trade openness. There is also some evidence that increased usage of international equity markets may have potentially negative spillover effects for other domestic firms in terms of stock turnover (Levine and Schmukler, 2006).

${ }^{20}$ Poor public governance (as measured by severity of bureaucratic corruption or lack of government transparency) discourages inward FDI and portfolio equity inflows (Wei (2001), Gelos and Wei (2005), and Doidge, Karolyi and Stulz (2005)).
} 
Financial integration also tends to have a disciplining effect on macroeconomic policies. Countries with higher levels of financial openness are more likely to generate better monetary policy outcomes in terms of lower inflation (Tytell and Wei, 2004; Gupta, 2006; Spiegel, 2008). By contrast, there is little systematic evidence of a relationship between financial openness and better fiscal policies. Indeed, one must strike a cautionary note that, in practice, easy access to foreign finance may simply allow profligate governments to run larger budget deficits for a longer period without being limited by domestic financing constraints — so long as international investors are willing to finance these deficits.

How do the indirect benefits of financial integration translate into economic growth? They could enhance the growth outcomes through their impact on total factor productivity. If financial integration is to have a lasting effect on growth, it must be by moving economies closer to their production possibility frontiers by eliminating various distortions and creating efficiency gains, for example, in financial intermediation, technological adoption etc. ${ }^{21}$ There appears to be a positive association between the extent of financial integration and productivity growth (Figure III.5). Bonfiglioli (2008) and Kose, Prasad and Terrones (2008a) have assembled some preliminary evidence suggesting that financial integration raises TFP growth.

\section{A Summary}

Although it is difficult to argue that the empirical evidence summarized here is decisive, the notion that financial globalization influences growth mainly through indirect channels has powerful implications for empirical analysis of its growth effects. ${ }^{22}$ Even after the effects take hold, however, they might be difficult to document. Standard growth regressions, which are used to evaluate the direct benefits of integration, already include measures of institutional quality, financial sector development, quality of macroeconomic policies etc. Yet, these may be the very channels through which financial integration generates growth benefits, making it difficult to disentangle the effects of financial integration. Moreover, the perspective of attaining collateral benefits through indirect channels could be helpful in designing policies to move forward on capital account liberalization. We will return to this topic later in the paper when we discuss policy issues.

\section{2. Macroeconomic Volatility and Patterns of International Risk-Sharing}

\section{III.2.1. Theory}

In theory, the effects of financial integration on output volatility are ambiguous. Financial integration allows capital-poor countries to diversify away from their narrow production bases

\footnotetext{
${ }^{21}$ Recent literature has emphasized the importance of TFP growth as the main driver of long-term GDP growth (see, e.g., Hall and Jones, 1999; Jones and Olken, 2005; Gourinchas and Jeanne, 2006).

${ }^{22}$ See Rodrik and Subramanian (2008) for a skeptical view on the literature on indirect benefits.
} 
that are often agricultural or natural resource-dependent, thereby reducing macroeconomic volatility. At a more advanced stage of development, however, trade and financial integration could together allow for enhanced specialization, as we have already noted. This could make middle-income developing countries more vulnerable to industry-specific shocks and thereby lead to higher output volatility (see Kose, Prasad and Terrones, 2004).

If financial integration takes the form of heavy reliance on external debt, it could expose these countries to world interest rate shocks and, thus, to higher output volatility. For example, Rodrik and Velasco (2000) find that the ratio of short-term debt to reserves is a robust predictor of financial crises among emerging market economies. They report that countries with a larger short-term debt stock than reserves are three times more likely to experience a sudden and massive reversal in financial flows. Their results also indicate that the severity of crises becomes more acute as the exposure to short-term debt increases.

Theory does have a strong prediction, however, about the relationship between financial integration and consumption volatility. Since consumers and, by extension, economies are riskaverse, consumption theory tells us that they should desire to use financial markets to insure against income risk, thereby smoothing the effects of temporary idiosyncratic fluctuations in income growth on consumption growth. While the benefits of international risk-sharing could be quite large in theoretical models, the magnitudes of these benefits depend on various modelspecific features. $^{23}$

Another prediction of theory, related to the consumption smoothing issue, concerns the crosscountry comovement of major macroeconomic aggregates. In theory, the effect of increased financial integration on cross-country correlations of output growth is uncertain, since it depends on the nature of shocks and specialization patterns. However, financial integration should in theory help countries diversify away country-specific risk and should, therefore, result in stronger comovement of consumption growth across countries.

\section{III.2.2. Empirical Evidence}

There has been a well-documented trend decline in macroeconomic volatility in most of the major industrial economies since the mid-1980s, although the reasons for this decline are still a matter of debate. Output volatility seems to have been on a declining trend in emerging market and developing economies as well. However, the existing evidence based on papers using a variety of regression models, different country samples and time periods leads to the conclusion that there is no systematic empirical relationship between financial openness and output

\footnotetext{
${ }^{23}$ In particular, the welfare gains depend on the volatility of output shocks, the rate of relative risk aversion, the risk-adjusted growth rate and the risk free interest rate in these models (see the discussion in Obstfeld and Rogoff, 2004, Chapter 5; Lewis, 1999; and van Wincoop, 1999). Recent research convincingly shows that the higher volatility that developing countries experience implies that they can potentially reap large benefits from international risk-sharing arrangements (see Pallage and Robe, 2003).
} 
volatility. This is not surprising since, as noted earlier, there is no consistent theoretical prediction across different models about how financial integration affects output volatility. ${ }^{24}$

Kose, Prasad and Terrones (2003b) note that, during the 1990s, average declines in output growth volatility were smaller for emerging markets than for either industrial or low-income developing economies. More importantly, they find that the ratio of consumption growth volatility to income growth volatility increased during the recent period of globalization for emerging market economies (and remained flat for the other two groups). What is surprising is not just that the volatility of consumption rose (perhaps because of crises experienced by some of these economies) but that it increased by more than income volatility. ${ }^{25}$ This result runs exactly counter to a presumed theoretical benefit of financial integration - that it allows countries to share income risk and smooth consumption.

In a related paper, Kose, Prasad and Terrones (2008b) examine the risk sharing implications of financial integration by focusing on the cross-country correlations of output and consumption. They report that, notwithstanding the prediction of conventional theoretical models that financial globalization should foster increased risk sharing across all countries, there is no evidence that this is true for developing countries. Even for the group of emerging market economies - which have become far more integrated into global markets than other developing countries-financial globalization has not improved the degree of risk sharing (Figure III.6). ${ }^{26}$

Both of these papers reach sobering conclusions about the stability and risk-sharing implications of financial globalization but as we discuss in the later sections their findings also depend on some country specific conditions and the level and composition of financial flows.

\section{III.2.3. Crises as Special Cases of Volatility}

The proliferation of financial crises is often viewed as one of the defining aspects of the intensification of financial globalization over the last two decades. Furthermore, the fact that

\footnotetext{
${ }^{24}$ See Razin and Rose (1994), Easterly, Islam, and Stiglitz (2001), and Buch, Dopke, and Pierdzioch (2005).

${ }^{25}$ Bekaert, Harvey, and Lundblad (2006) find that, following equity market liberalizations, there is a decline in consumption volatility. These results differ from those of Kose, Prasad and Terrones (2003b) due to differences in the definitions of financial integration, the measures of consumption volatility, data samples, and methodologies. The results in Bekaert, Harvey, and Lundblad (2006) suffer from the same problems noted about their work on the impact of equity market liberalizations on economic growth. ${ }^{26}$ A number of papers show that the synchronicity of national business cycle fluctuations (in both industrial countries and emerging market economies) and the relative importance of global (and/or) regional factors for these fluctuations has increased during the period of globalization (see Kose, Otrok, and Whiteman (2008); and Kose, Otrok, and Prasad (2008)). Imbs (2006) documents that financial integration has led to higher cross-country consumption and output correlations among industrialized economies. Kose, Prasad and Terrones (2003a) document changes in output comovement across a broader group of industrial and developing economies and link these changes to financial integration. Contrary to the predictions of theory, they document that, on average, cross-country correlations of consumption growth did not increase in the 1990s, precisely when financial integration would have been expected to result in better risk-sharing opportunities for developing economies.
} 
recent crises have affected mainly emerging market economies has led to these phenomena being regarded as hallmarks of the unequal distribution of globalization's benefits and risks (Desai, 2003). This raises a challenging set of questions about whether the nature of crises has changed over time, what factors increase vulnerability to crises, and whether such crises are an inevitable concomitant of financial globalization. These crises can be regarded as particularly dramatic episodes of volatility. While the research on the impact of financial integration on volatility and risk sharing has resulted in somewhat negative results, recent research analyzing the effects of integration on crises has painted a different picture.

Some papers that have analyzed the effects of capital controls on susceptibility to financial crises have found that countries with capital controls are in fact more subject to crises. But this could simply be because of a "selection effect"- often it is countries with poor macroeconomic fundamentals that put controls in place to try and insulate themselves from crises. Glick, Guo and Hutchison (2006) address this issue--they find that capital account openness reduces the probability of currency crises, even after controlling for selection bias in terms of how macroeconomic policies influence the existence of capital controls. ${ }^{27}$ The relationship between capital controls and crises could also reflect the fact that some of the countries are actually more integrated in terms of de facto measures of integration (capital flight) and that capital controls therefore do not insulate them from crises. We provide a detailed analysis of the macroeconomic implications of capital controls later in the chapter.

Edwards (2005) examines this issue using a new measure of de jure financial openness that attempts to capture the intensity of capital account restrictiveness. He looks at two manifestations of external crises - sudden stops of inflows and current account reversals--and finds no evidence that countries with higher capital mobility tend to have a higher incidence of crises. In subsequent work, Edwards (2006) concludes that there is no evidence that the output costs of currency crises are smaller in countries that restrict capital mobility.

While currency crises have been emphasized in the literature on the risks of capital account liberalization, it is worth noting that banking crises account for about one-third of financial crises over the last three decades and that their frequency increased in the 1980s and 1990s. Banking crises tend to be more disruptive and generally have larger adverse effects on output growth than currency crises. Glick and Hutchison (2001) find little evidence that capital account liberalization by itself affects vulnerability to banking crises; moreover, the adverse effects of banking crises seem to be weaker for countries with open capital accounts. ${ }^{28}$

In sum, there is little formal empirical evidence to support the oft-cited claims that financial globalization in and of itself is responsible for the spate of financial crises that the world has seen

\footnotetext{
${ }^{27}$ These authors use a binary capital account openness indicator based on the IMF's AREAER. Whether this relationship holds up with de facto measures remains to be seen.

${ }^{28}$ On the output costs of banking crises, see Hutchison and Noy (2005) and Bonfiglioli and Mendicino (2004).
} 
over the last three decades. ${ }^{29}$ Of course, as we will discuss in more detail below, the interaction between capital account liberalization and other policy choices (e.g., fixed exchange rate regimes that are not well supported by other macroeconomic policies) could, under certain circumstances, spell trouble for a developing economy.

\section{Economic Policies and Growth Outcomes}

Researchers have explored a number of avenues to reconcile the strong theoretical prediction that financial integration should boost long-run growth and reduce the risks of consumption instability in developing economies with the weak empirical evidence. Some authors have argued that countries that do not have the right initial conditions associated with certain structural and macroeconomic factors can experience growth surges due to financial integration but they inevitably experience crises, which pulls down their long-run growth. Other authors have argued that financially integrated developing countries that lack these factors are not able to derive the full benefits of financial integration even if they can escape crises.

Kose et. al. (2006) pull these two lines of argument together to describe the conditioning variables that influence the relationship between financial integration and growth as a set of "threshold conditions." These threshold conditions help determine the nature of policy measures that could improve the growth and stability benefits of financial globalization. They include an economy's structural features--the extent of financial sector development, institutional quality, and trade integration--and also the macroeconomic policy framework.

Before getting into the details of theoretical arguments and empirical findings in the literature, we first present some preliminary observations on whether there are obvious threshold effects in the data based on recent work by Kose, Prasad and Taylor (2008). ${ }^{30}$ In particular, our interest is in whether, within the groups of emerging markets and other developing countries, the levels of certain conditioning variables are positively associated with economic performance. Table IV.1 compares unconditional and conditional growth rates over the period 1975-2004 for countries that are above or below the within-group sample medians for various variables that have been put forward as threshold variables in the related theoretical and empirical literature.

\footnotetext{
${ }^{29}$ The evidence cited on this point by some prominent critics of financial globalization in fact turns out to be about how domestic financial sector liberalization, rather than financial integration, has in some cases precipitated financial crises (see footnote 5 in Stiglitz, 2004).

${ }^{30}$ A key empirical issue is about the definition of thresholds. Kose, Prasad and Taylor (2008) provide a comprehensive analysis of threshold effects in the process of financial integration. They employ three different approaches: (i) A linear interaction between financial openness and the threshold variable. This approach just tests for whether the level of a particular variable affects the marginal effect of financial openness on growth; (ii) A quadratic interaction that allows for nonlinearity in the effect of the threshold variable.; and (iii) A high-low cutoff based on the sample median of a threshold variable. This exogenously sets the threshold but it does provide a simple way of testing if the level of a particular variable matters in terms of the quantitative effect of openness on growth outcomes.
} 
The main findings from this table can be summarized as follows: First, unconditional growth rates in emerging market countries are greater for those countries with higher (within-group above-median) levels of the illustrative threshold indicators for financial development, trade openness, institutional quality, and macro policies, although this difference is not always statistically significant. These effects are less pronounced in other developing countries. However, for institutional quality the pattern is reversed. Second, for conditional growth rates, the patterns are less pronounced although across many indicators the positive association of growth with higher thresholds remain. Third, the difference between the growth rates of emerging markets and other developing countries is more pronounced for the sub-samples with higher levels of the thresholds.

Our preliminary exploration lends support to the notion of various factors related to a country's structural characteristics and macroeconomic policy choices playing a role in the relationship between financial openness and growth. However, clearly it abstracts from issues relating to endogeneity or the nature of any threshold relationship. To address these and other related issues we provide a review of the theoretical and empirical literature on the importance of structural features and macroeconomic policies in the next section. For each of these factors, we review the underlying theoretical arguments and survey the relevant empirical evidence.

\section{Structural Characteristics and Economic Policies}

\section{V.1. Financial Sector Development}

\section{Theory}

There is a strong theoretical presumption that financial sector development not only enhances the growth benefits associated with financial globalization but also reduces vulnerability to crises. It is intuitive that well-developed domestic financial markets are instrumental in efficiently allocating foreign financial flows to competing investment projects (Wurgler, 2000). A number of more formal models have been developed to analyze the effects of capital account liberalization in economies with limited financial development. Domestic and international collateral constraints could play a particularly important role in financially underdeveloped economies where access to arm's length financing is limited. Caballero and Krishnamurthy (2001), Aghion, Bacchetta, and Banerjee (2004), Mendoza, Quadrini and Rios-Rull (2007) and Aoki, Benigno, and Kiyotaki (2007) show how, in different theoretical settings, the interaction of these constraints can lead to unpredictable and, occasionally, adverse effects of capital account liberalization.

Financial development also has a direct impact on macroeconomic stability in financially open economies. Sudden changes in the direction of capital flows tend to induce or exacerbate boombust cycles in developing countries that lack deep and well-functioning financial sectors (Caballero and Krishnamurthy, 2001; Aghion and Banerjee, 2005). Moreover, inadequate or 
mismanaged domestic financial sector liberalizations have been a major contributor to crises associated with financial integration (Mishkin, 2006). The lack of well-developed financial markets also appears to be a key reason explaining the positive association between financial integration and the relative volatility of consumption growth documented by Kose, Prasad and Terrones (2003b). ${ }^{31}$

\section{Empirical Evidence}

There has been a large empirical literature analyzing the role of financial development in determining the impact of financial integration on economic growth (see Table A). The main indicators of financial development used are private credit and stock market capitalization to GDP, although these might be better described as indicators of financial depth. In terms of financial openness, the main indicators used are either inward foreign direct investment (FDI) or measures of capital controls while equity flows and liberalizations of equity markets are also employed in some cases.

Using a large sample of developing countries over the period 1970-1995, Hermes and Lensink (2003) find that, in order to enjoy the growth benefits of FDI, a threshold level of financial sector development is a prerequisite. While more than half of the countries in their sample (mostly in Latin America and Asia) appear to meet the necessary threshold, almost all of the countries in sub-Saharan Africa, with their relatively weak financial systems, are below this level. Alfaro et al. (2004), Carkovic and Levine (2005) and Durham (2004) also find that the growth impact of FDI is stronger in economies with well-developed financial sectors. However, the implied financial development thresholds for a positive financial openness coefficient vary substantially within and across these four studies (Kose, Prasad and Taylor, 2008). For example, the credit to GDP thresholds (from cross-section regressions) vary from 13 percent to 48 percent. This is likely to reflect different time and country samples and also different credit measures employed. Financial sector development also appears to improve the growth benefits of equity flows. For example, Bekaert et al (2005) and Hammel (2006) find that growth following equity market liberalizations (which allow foreign investors to invest in domestic stock markets) is higher for countries with higher private credit/stock market turnover and stock market capitalization, respectively. ${ }^{32}$

\footnotetext{
${ }^{31}$ For instance, Levchenko (2005) and Leblebicioglu (2006) consider dynamic general equilibrium models where only some agents have access to international financial markets. In both models, capital account liberalization leads to an increase in the volatility of aggregate consumption since agents with access to international financial markets stop participating in risk-sharing arrangements with those who do not have such access.

${ }^{32}$ Using broader measures of financial openness, Prasad, Rajan and Subramanian (2007) find evidence of high/low interaction effects among non-industrial countries while Kraay (1998) and Arteta et al (2003) find little evidence of interaction effects.
} 
Another major benefit of financial sector development is its positive impact on macroeconomic stability, which in turn has implications for the volume and composition of capital flows. In theory, by expanding the scope of diversification possibilities, developed financial markets moderate the effects of shocks and help reduce macroeconomic volatility. ${ }^{33}$ Economic crises in emerging markets have repeatedly demonstrated the importance of deep and well-supervised domestic financial markets during the process of financial integration. Mishkin (2006) discusses how, after capital account liberalization, excessive risk taking by domestic banks played a major role in triggering the financial crises in Mexico in 1994 and many East Asian countries in 1997. Ishii et. al. (2002) document that countries with stronger financial systems generally avoided crises following capital account liberalization. However, countries with underdeveloped and poorly supervised financial markets suffered financial crises after liberalizing their capital accounts. Recent empirical work also finds that in countries with deeper domestic financial markets, financial integration is indeed associated with lower consumption growth volatility (Eozenou, 2006; and IMF, 2007).

\section{V.2. Institutional Quality}

\section{Theory}

Institutional quality has also received considerable attention as an important structural factor in the relation between financial openness and growth. The quality of corporate and public governance, the legal framework, the level of corruption, and the degree of government transparency can affect the allocation of resources in an economy. Since capital inflows make more resources available, the quality of institutions therefore matters much more for financially open economies. For instance, post-mortems of the Asian financial crisis have pinned a significant portion of the blame on crony capitalism that was encouraged and facilitated by corruption and weak public governance (Haber, 2002; Krueger, 2002). Indeed, an intermediate degree of financial openness with selective capital controls may be most conducive to crony capitalism, as it gives politically well-connected firms preferential access to foreign capital (Johnson and Mitton, 2002). We discuss issue later again in the context of capital controls as a policy instrument.

Weak protection of property rights in poor countries means that foreign financing may not be directed to long-gestation, investment-intensive, and low-initial profitability projects (including infrastructure) where such financing could be particularly useful given domestic financing constraints (see Rajan and Zingales, 1998). Some authors have argued that, while factors such as weak macro policies are indeed precursors of crises, the deep determinants of bad macroeconomic and structural policies can in fact be traced back to weak institutions (Acemoglu

\footnotetext{
${ }^{33}$ See Easterly, Islam, and Stiglitz (2001), Beck, Lundberg and Majnoni (2001), Denizer, Iyigun, and Owen (2002), and Larrain (2004).
} 
et al, 2003). These models imply that there may be important interactions among the threshold conditions themselves in determining the growth and volatility effects of financial integration.

\section{Empirical Evidence}

Empirical evidence suggests that institutional quality appears to play an important role in determining not just the outcomes of financial integration but the level of de facto integration itself. Furthermore, institutional quality also appears to have a strong influence on the composition of inflows into developing economies, which is another channel through which it affects macroeconomic outcomes.

A number of empirical studies find that better institutions appear to enhance the growth benefits of capital account liberalization. A range of indicators for both institutions and financial openness has been employed in the empirical literature, with the interaction terms having varying degrees of significance across studies (see Table B). Kraay (1998) and Quinn and Toyoda (2006) argue that there is little evidence of interaction effects while Bekaert et al (2005) and Chanda (2005) are more supportive. Klein (2005) finds that only intermediate levels of institutional quality are associated with a positive correlation between growth and capital account liberalization. This hints at the possibility of nonlinear threshold effects. Chanda (2005) finds that the cross-country relationship between capital controls and growth depends on the degree of ethnic heterogeneity, which he interprets as a proxy for rent-seeking and common pool problems. For countries with more heterogeneity (more competing groups), capital controls lead to greater inefficiencies and lower growth. ${ }^{34}$

As an alternative to using indices of institutional quality, a country's level of income has been used as a proxy for overall institutional development and interacted in a similar manner with financial openness measures. These studies report mixed results. Edwards (2001) and Edison et al (2004) find evidence of a positive significant linear interaction and an inverted U-shaped relationship, respectively. However, other papers examining these linkages, such as Arteta et al (2003) and Quinn and Toyoda (2006), both of which use de jure measures, and Carkovic and Levine (2005), which uses FDI flows as a measure of financial openness, fail to find evidence of income levels influencing the growth effect of financial openness.

Moreover, better institutional quality increases the level of inflows. In particular, governance and institutional indicators seem to have a quantitatively significant influence on FDI inflows. Based on the distribution of U.S. multinational firms around the world, Hines (1995) reports that American companies tend to invest less in destination countries where levels of corruption are

\footnotetext{
${ }^{34}$ IMF (2007) provides empirical evidence about the conditioning role of institutional quality in governing the relationship between financial integration and consumption volatility. In particular, the study reports that financial integration is often associated with higher consumption volatility in countries with relatively poor institutional structures.
} 
higher. Using bilateral stocks of FDI from 12 OECD source countries to 45 host countries, Wei (20001) shows that countries' corruption levels are negatively associated with inward FDI (Figure V.1). An increase in the corruption level from that of Singapore to that of Russia has the same negative effect on FDI as raising the marginal corporate tax rate by as much as 50 percentage points. Moreover, for any given level of corruption, less centralized and more arbitrary types of corruption tend to discourage FDI even more strongly. Better governance also appears to lead to more equity inflows (see Gelos and Wei, 2005).

There is a considerable body of evidence that institutions affect the structure of a country's capital inflows in a systematic way. This has important consequences for the outcomes associated with financial globalization since the composition of inflows seems to have strong predictive power for currency crashes. In particular, the share of FDI in a country's total capital inflows is negatively associated with the probability of a currency crisis (see, e.g., Frankel and Rose, 1996; Frankel and Wei, 2005). Other dimensions of composition are the maturity structure of external debt (the greater the share of short-term debt, the more likely a crisis), and the currency denomination of external debt (the greater the share of foreign currency debt, the more likely a crisis). ${ }^{35}$

Wei (2001) and Wei and $\mathrm{Wu}$ (2002) suggest that countries with better public institutions are more likely to attract more direct investment relative to bank loans. These authors provide evidence based on total inflows (based on data from the IMF's Balance-of-Payments Statistics) and bilateral flows from source to destination countries (based on bilateral FDI data from the OECD and bilateral bank lending data from the BIS) (Figure V.2).

Faria and Mauro (2005) find that better institutional quality helps tilt a country's capital structure towards FDI and portfolio equity flows which tend to bring more of the collateral benefits of financial integration. These authors find that, in a cross-section of emerging markets and other developing countries, equity-like liabilities as a share of countries' total external liabilities (or as a share of GDP) are positively associated with indicators of institutional quality. ${ }^{36}$

\footnotetext{
${ }^{35}$ Hausmann and Fernandez-Arias (2000) provide a contrarian view on the determinants and implications of the composition of flows to developing countries. Albuquerque (2003) argues that financially constrained countries are likely to get more FDI than other types of flows since it is harder to expropriate - not because it is more productive or intrinsically less volatile. Ju and Wei (2006) provide a framework to reconcile the results of these two papers with those of other authors arguing that it is crucial to distinguish between property rights institutions and financial institutions.

${ }^{36}$ Their measure of institutional quality is an average of six indicators - voice and accountability, political stability and absence of violence, government effectiveness, regulatory quality, rule of law, and control of corruption - from Kaufmann, Kraay and Mastruzzi (2003). Faria and Mauro instrument the institutional index using settler mortality (Acemoglu, Johnson, and Robinson, 2001) and ethno-linguistic fragmentation. The IV approach reaffirms their basic conclusion.
} 


\section{V.3. Trade Openness}

\section{Theory}

Trade integration improves the growth and stability benefits of integration through various channels. First, trade integration reduces the probability of crises associated with sudden stops and current account reversals. Economies that are less open to trade have to undergo larger real exchange rate depreciations for a given current account adjustment, face more severe balance sheet effects stemming from depreciations, and, as a result, are more likely to default on their debt. This creates a link between the probability of sudden stops and the likelihood of default, implying that more open economies are less vulnerable to financial crises. ${ }^{37}$ In addition, trade integration is also expected to mitigate the adverse growth effects of financial crises and facilitate recoveries from crises. It could help an economy to continue servicing its debt and export its way out of a recession since a given exchange rate depreciation would have a larger impact on its export revenues than in a less open economy.

Moreover, trade integration in general seems to be less risky than financial integration. For example, while trade integration can apparently proceed well even in the absence of financial integration, financial integration in the absence of trade integration could lead to a misallocation of resources. Eichengreen (2001) notes that, under these circumstances, capital inflows may be directed to sectors in which a country doesn't have a comparative advantage. Martin and Rey (2006) constructs a model in which trade integration has a positive growth effect, but financial integration can lead to asset price crashes and financial crises. They argue that costs associated with international trade in goods and assets alone could increase the vulnerability of developing countries to financial crises. ${ }^{38}$ The model has a clear implication-consistent with the received wisdom - that developing countries should liberalize trade in goods before trade in financial assets.

\section{Empirical Evidence}

There are many papers validating the traditional preference for liberalizing trade flows ahead of financial flows, but the empirical evidence that trade integration significantly affects the relationship between financial integration and growth is mixed (see Table C). Using trade openness (exports plus imports to GDP) interacted with FDI inflows, Balasubramanyam et al (1996) find a positive coefficient on FDI for a sub-sample of countries with higher imports to GDP but Carkovic and Levine (2005) do not find significant interaction effects. Gupta and Yuan (2006) use sectoral-level data and find that there is higher growth following international equity market liberalizations in those sectors that are more trade competitive (defined as the ratio of

\footnotetext{
${ }^{37}$ See Calvo, Izquierdo, and Mejia (2004) and Frankel and Cavallo (2004).

${ }^{38}$ Obstfeld and Rogoff (2001) emphasize the importance of frictions related to trade costs (broadly defined) for explaining a number of puzzles in international macroeconomics.
} 
annual exports in each industry to total annual output of that industry across all sample countries).

Citing the lack of empirical evidence from a couple of empirical studies focusing on Morocco and Venezuela, Rodrik (1999) argues that FDI has no extra benefit to host country development. ${ }^{39}$ Moran (2005) contests this argument, noting that both of these countries practiced import-substitution based trade policies during the periods analyzed in these papers. He provides several case studies showing that the full benefits of FDI are realized only in an environment with minimal distortions from trade barriers and other protectionist policies.

However, there appears to be evidence favoring other channels emphasized by the theory. For example, the negative impact of trade openness on the likelihood of sudden stops is indeed empirically important. Calvo, Izquierdo, and Mejia (2004) show that trade openness makes countries less vulnerable to financial crises, including sudden stops and currency crashes; controlling for the endogeneity of trade strengthens this effect. Frankel and Cavallo (2004) and Cavallo (2005) report similar findings. They conclude that a 10 percentage point increase in trade openness reduces the probability of a sudden stop by about 30 percent.

Does trade integration play an important role during the recovery phases from crises? Calvo and Talvi (2005) claim that the collapse of capital flows to Argentina and Chile in the 1990s had a smaller impact on Chile since it is more open to trade flows. ${ }^{40}$ Recent research also confirms that, among countries that have experienced sudden stops and current account reversals, those that are more open to trade suffer smaller growth declines. ${ }^{41}$ For example, Edwards (2005) reports that a decline in trade openness by roughly 30 percentage points increases the negative effect of a current account reversal on growth by approximately 1.2 percentage points.

Recent research also analyzes how trade and financial integration affect the negative relationship between volatility and economic growth. Although countries prone to higher macroeconomic volatility would be expected to show worse growth performance than more stable ones, this interpretation does not seem to be entirely borne out by the data. ${ }^{42}$ In particular, while emerging market countries affected by the recent financial crises faced episodes of high output volatility,

\footnotetext{
${ }^{39}$ The studies cited by Rodrik are Haddad and Harrison (1993) and Aitken and Harrison (1999). These two papers examine the role of horizontal spillovers--productivity spillovers from foreign firms to domestic firms in the same sector--in transmitting the productivity benefits of FDI to Morocco and Venezuela. Lipsey (2004) also notes that Morocco and Venezuela were relatively closed to trade during the periods covered by the panel datasets used in these studies.

${ }^{40}$ Kose, Meredith, and Towe (2005) argue that trade integration has made the Mexican economy more resilient to shocks and contributed to its faster recovery from the 1994-95 peso crisis than from the 1982 debt crisis.

${ }^{41}$ See Edwards (2004, 2005), Desai and Mitra (2004), and Guidotti, Sturzenegger and Villar (2004).

${ }^{42}$ Ramey and Ramey (1995), Aghion and Banerjee (2005), and Aizenman and Pinto (2006) document the negative relationship between growth and volatility.
} 
they actually posted much better growth rates on average during the past two decades than other developing countries. In particular, during the period 1986-2005, while a number of emerging markets experienced financial crises, their average growth of output was more than two times higher than that of other developing economies. Does this mean that, in a period of rising globalization, the negative relationship between volatility and growth has changed?

Recent research addresses this question by studying the relationship between growth and volatility in a large sample of countries over the past four decades (Kose, Prasad and Terrones, 2005 and 2006). The results indicate that while the negative relationship between growth and volatility reported by previous research for the period 1960-85 has persisted into the 1990s, when it is broken down by country groups, it is far from homogeneous (Figure V.3). The relationship appears positive for advanced countries - indicating that, for countries in advanced stage of development and integration into the global economy, volatility is not necessarily associated with lower growth (Figure V.4). Among developing countries, it is positive on average for emerging market economies and negative for the other developing countries that have not participated as much in the process of globalization.

Both trade and financial integration appear to have played important roles in changing the nature of the volatility and growth relationship for emerging market economies. The relationship between growth and volatility is negative before trade liberalization and positive after (Figure V.5). For financial integration, there is a similar, although less strong, result. In other words, there is suggestive evidence from emerging market economies that both trade and financial integration change the sign of the relationship between volatility and growth.

Regression analysis also suggests that although volatility is still negatively associated with growth, higher trade and financial integration make this relationship weaker. In other words, economies that are more integrated into the global economy have the ability to withstand higher levels of volatility with less adverse effects on growth. ${ }^{43}$ Moreover, they argue that these effects may be quantitatively important. When comparing the growth/volatility performance of advanced and developing countries, it is found that the higher levels of trade/financial openness of emerging markets could, under some assumptions, account for about 40 percent of the observed difference in average growth rates between these country groups. Overall these findings suggest that the forces of trade and financial integration could help reduce the adverse impact of volatility on economic growth.

\footnotetext{
${ }^{43}$ While FDI flows help dampen the adverse impact of volatility on economic growth, other types of flows do not appear to have a significant effect on the relationship between volatility and growth (Kose, Prasad and Terrones, 2005).
} 


\section{Macroeconomic Policies}

\section{VI.1. Theory}

Financial integration is expected to produce better growth outcomes when it is supported by good macroeconomic policies, which includes fiscal, monetary, and exchange rate policies (Eichengreen, 2000). Moreover, weak or incompatible policies can increase the risk of crises from an open capital account. For instance, the combination of a fixed exchange rate and an open capital account has been implicated in a number of currency crises (Obstfeld and Rogoff, 1995; and Wyplosz, 2004). Similarly, managing the effects of capital inflows can be especially complicated in developing economies with large fiscal deficits and procyclical fiscal policy (Kaminsky, Reinhart, and Vegh, 2004). All of this suggests that opening the capital account creates incentives for policymakers to maintain stable policies as discussed in section III. This logic has led to the proposition that capital account liberalization can serve as a commitment device for disciplining macroeconomic policies (Bartolini and Drazen, 1997; and Gourinchas and Jeanne, 2006). A different view is propounded by Neut and Velasco (2003) who argue that such a commitment device could actually backfire in the presence of uncertainty- the possibility of unavoidable debt defaults due to large adverse shocks could result in a conservative policymaker having lower credibility.

\section{VI.2. Evidence}

There is a large literature tying the quality of policies to macroeconomic performance, vulnerability to crises, and the level and composition of inflows. For example, using the black market premium on the domestic currency as an indicator of the extent of macro imbalances, Arteta, Eichengreen and Wyplosz (2003) report evidence of threshold effects related to good macro policies in generating positive growth effects of financial openness. These positive effects are present only when macroeconomic imbalances that lead to inconsistencies between the administered exchange rate and other policies have first been eliminated (i.e., if there is no large black market premium). Mody and Murshid (2005) examine how policies affect the relationship between financial flows and domestic investment growth. Using a composite variable of macroeconomic policy quality constructed by the World Bank, they find that financial flows have a stronger impact on investment growth in countries with better macro policies. In models of early warning systems, proxies for exchange rate and monetary policies appear to be important for predicting financial crises. ${ }^{44}$

These results are further supported by a large volume of case studies. For example, IMF (2007)

\footnotetext{
${ }^{44}$ See Berg, Borenzstein, and Patillo (2004). Eichengreen, Rose, and Wyplosz (1995) show that these issues are relevant for more advanced economies as well. Using quarterly panel data for 20 OECD countries over the period 1959-1993, they document that high money and credit growth as well as large deficits in current account and fiscal positions tend to raise the probability of devaluations.
} 
undertakes a study analyzing a number of countries' experiences with the process of capital account liberalization. It concludes that while the speed of liberalization process does not appear to affect the crisis propensity, countries with increasing inflation, expansionary fiscal policies and rising current account deficits are more likely to experience a financial crisis than those with relatively lower inflation, strong fiscal positions, and low current account deficits. These results confirm the earlier findings in Ishii et al. (2002) country case study which underscores the importance of stable macro policies for averting crises in countries with open capital accounts.

With respect to fiscal policy, for obvious reasons there has been a large research program focusing on the importance of fiscal prudence. Countries that consistently face problems associated with government debt (referred to as "serial defaulters" by Reinhart and Rogoff, 2004b) are more likely to benefit from financial globalization if their governments simultaneously take policy measures to avoid an excessive buildup of debt. In a related paper, Reinhart, Rogoff, and Savastano (2004) study the concept of "debt intolerance", which manifests itself in the extreme duress many emerging market economies experience at overall debt levels that would seem quite manageable by the standards of the advanced industrial economies. They conclude that, for debt-intolerant countries, mechanisms to limit borrowing through institutional change on the debtor side can greatly limit the risks associated with financial integration. ${ }^{45}$

The design of macroeconomic policies naturally becomes more complex during the periods of large capital inflows. ${ }^{46}$ Cardarelli, Elekdag and Kose (2007) examine the macroeconomic outcomes associated with various policy responses in over 100 episodes of large net capital inflows in a number of countries during the past two decades. Their results emphasize the importance of employing disciplined fiscal and monetary policies to cope better with the macroeconomic effects of large capital inflows. ${ }^{47}$ For example, keeping government spending along a steady path - rather than engaging in excessive spending during inflow episodesappears to mitigate the adverse effects of large inflows as it helps reduce upward pressures on both aggregate demand and the real exchange rate. With respect to monetary policies, they document that a higher degree of resistance to exchange rate pressure during the inflow period and a greater degree of sterilization of the resulting increase in money supply were not associated with lower real appreciation or with better post-inflow growth performance.

\footnotetext{
${ }^{45}$ There are of course various ways to limit fiscal excess in developing countries. These include legislation of fiscal limits and greater transparency of public accounts (see Obtfeld, 2007).

${ }^{46}$ A number of studies have examined the policy responses to capital inflows focusing mainly on the experience of a few countries during the 1990s (see Calvo, Leiderman, and Reinhart (1994); FernándezArias and Montiel (1996); Glick (1998); Montiel (1999); Reinhart and Reinhart (1998); and Edwards (2000)).

${ }^{47}$ Their findings provide helpful guidance on what has worked, and not worked, in the past. The appropriate policy response to large capital inflows of course depends on a variety of country-specific circumstances, including the nature of the underlying inflows, the stage of the business cycle, the fiscal policy situation, and the quality of domestic financial markets also matters.
} 


\section{Monetary and Exchange Rate Policies}

There has been a growing research program analyzing the links between financial globalization and exchange rate policy. ${ }^{48}$ The choice of appropriate exchange rate regime itself has received much attention in the literature (see the chapter by Levy Yeyati and Sturzenegger in this Handbook). An open capital account is likely to put a greater burden on other policies and structural features of the economy (e.g., product and labor market flexibility) to support a fixed exchange rate. In particular, for economies with weak financial systems, an open capital account and a fixed exchange rate regime are not an auspicious combination. Indeed, there is a compelling case to be made that rigid exchange rate regimes can make a country more vulnerable to crises when it opens its capital markets. For example, Prasad, Rumbaugh and Wang (2005) survey a number of industrial and developing country experiences showing that the combination of capital account liberalization and a fixed exchange rate regime have often ended in forced and messy exits to more flexible exchange rate regimes. It can be argued that, in the absence of de facto or de jure fixed rates, most of the crises of the 1990s, from Mexico to Asia to Russia to Brazil, might have been much less virulent, or might even have been avoided entirely.

However, the literature does not imply that fixed exchange rates are necessarily a problem for countries that are at early stages of domestic financial development or that they are inappropriate prior to international capital market liberalization. Husain, Mody and Rogoff (2005), using the de facto approach to classifying exchange rate regimes developed by Reinhart and Rogoff (2004), find that pegged exchange rate regimes confer some advantages such as lower inflation upon developing countries that do not have much exposure to international capital. For emerging markets, standard measures of macroeconomic performance are not systematically associated with the nature of the exchange rate regime, but the likelihood of financial crises is higher for countries with pegged or nearly pegged exchange rates. Husain, Mody and Rogoff attribute the latter result under a regime with "hard commitment" to the inability to adapt to changed circumstances, the incentives of economic agents including entrepreneurs and financial intermediaries to undertake risky activities on the presumption that exchange rates will not change, and speculative pressures from investors who seek to test the commitment. ${ }^{49}$

Wyplosz (2004) highlights the difficulties and risks associated with maintaining currency pegs when the capital account is open. As a short-term strategy for developing economies, he recommends a combination of a soft peg or managed exchange rate regime along with welldesigned limits on capital mobility. Maintaining either a free float or a hard peg along with

\footnotetext{
${ }^{48}$ These authors provide an extensive survey of the effects of monetary and exchange rate policies on economic growth. For analyses of the impact of financial globalization on monetary policy, see also Obstfeld (2007), Rogoff (2007) and Woodford (2007).

${ }^{49}$ These authors also find that that banking crises are more likely under rigid exchange rate regimes. They note that this result is opposite to that of Ghosh, Gulde and Wolf (2003) and trace the differences to the latter authors' use of a de jure exchange rate regime classification.
} 
capital account openness requires a strong commitment to fostering good institutions, especially with respect to financial market regulation and supervision.

In a recent paper, Rodrik (2007) suggests that an undervalued real exchange rate helps promote economic growth. His main argument is that the tradable sector in a developing economy is more likely to suffer from various institutional and market failures than the non-tradable sector. A subsidy in the form of an undervalued exchange rate is a useful offset to these problems. He notes that there are a variety of policies through which countries can keep their real exchange rates undervalued. Among other policy measures, his list also includes imposition of controls on inflows, liberalization of capital outflows, and intervention in foreign exchange markets in order to sustain exchange rate undervaluation.

\section{Direction of Capital Flows and Economic Growth}

\section{Empirical Evidence}

As we discuss earlier in section III, standard economic theory predicts that financial flows should, on net, flow from richer to poorer countries. That is, it should flow from countries that have more physical capital per worker - and hence where the returns to capital are lower - to those that have relatively less capital - and hence greater unexploited investment opportunities. In principle, this movement of capital should make poorer countries better off by giving them access to more financial resources that they can then invest in physical capital and improve their growth prospects.

However, the actual volumes of such flows do not come anywhere near what the baseline models predict, as famously emphasized by Lucas (1990). ${ }^{50}$ Remarkably, as shown by Prasad, Rajan and Subramanian (2007), this paradox has, if anything, intensified over time as financial globalization has picked up momentum. ${ }^{51}$ The average income, relative to the United States, of capital-exporting countries has fallen well below that of capital-importing countries (Figure VII.1). In other words, capital has been flowing from poor to rich countries implying that

\footnotetext{
${ }^{50}$ Lucas himself offered a new growth model based on increasing returns to human capital to explain what was then a low volume of net flows to developing countries, though recent work has tended to focus more on the financial channel emphasized contemporaneously by Gertler and Rogoff (1990). Caballero, Farhi and Gourinchas (2006), Mendoza, Quadrini, and Rios-Rull (2007) and Alfaro, Kalemli-Ozcan and Volosovych (2006) argue that institutional failures more generally may lead to capital flow reversals. Reinhart and Rogoff (2005) suggest that recurrent defaults and financial crises in developing countries may depress investment there. Gordon and Bovenberg (1996) focus on the role played by information asymmetries.

${ }^{51}$ Gourinchas and Jeanne (2006) document that net capital flows from rich to poor countries often end up in countries with relatively low productivity. They argue that this constitutes a major challenge for the standard models often employed to evaluate the implications of financial integration.
} 
increasing the quantum of financing available for investment is not the channel through which financial globalization delivers its benefits for developing countries.

Prasad, Rajan and Subramanian (2007) provide further evidence why the direct channel emphasized by the standard theory does not work. In particular, they examine the long-run relationship between current account balances and growth. Countries that borrow more from abroad should be able to invest more (since they are less constrained by domestic saving) and, therefore, should grow faster. Surprisingly, for their sample of nonindustrial countries, the correlation between growth and current accounts using data averaged over a long period for each country is positive (Figure VII.2). In other words, developing countries that have relied less on foreign finance have grown faster in the long run. That is not to say there are no episodes where nonindustrial countries grow fast and run large current account deficits-East Asia before the crisis is a clear counter example. But, looking beyond a few short-run foreign-funded booms (and possibly busts), on average, and in the long run, nonindustrial countries that grow the fastest have not depended much on foreign finance.

\section{How to interpret these findings?}

How does one interpret the finding that there is a positive correlation between the current account surplus and a country's growth rate? One possible explanation is that the relationship reflects and is driven by domestic savings, which is either determined by deeper forces or generated through growth itself. After all, if foreign inflows responded largely to investment opportunities, there should be an unambiguously negative relationship between growth and the current account.

Indeed, it turns out that the positive correlation is driven largely by national savings. That is, nonindustrial countries that have higher savings for a given level of investment experience higher growth. Of course, investment in high-saving countries could also be higher, so high domestic savings does not imply low reliance on foreign savings. As expected, countries with higher levels of investment do fare better than those with lower levels (Figure VII.3). What is interesting is that countries that had high investment ratios and lower reliance on foreign capital (lower current account deficits) grew faster-on average, by about 1 percent a year-compared with countries that had high investment but also a greater degree of reliance on foreign capital.

One explanation for the positive correlation between the current account surplus and a country's growth rate is that higher growth is associated with - and itself generates--higher domestic savings. In other words, fast growing countries may need less foreign capital. The problem is that, typically as countries grow (i.e. when they experience a positive productivity shock) they should want to consume more (because they are richer) and invest more (because of the investment opportunities). Thus, the correlation should, if anything, be negative. 
This is where the financial system - especially an underdeveloped one-can play a role. If the financial sector were deep and efficient, a sustained increase in productivity would not only result in more investment (as firms borrow to take advantage of investment opportunities) but also more consumption as consumers borrow to consume in anticipation of their higher income. Conversely, a weak financial sector could translate a sustained increase in the productivity of certain sectors into weaker investment growth and greater savings growth. Corporate investment could be limited to the funds firms generate internally from past investment, while consumers save much of the increased income stemming from the increase in productivity because they cannot borrow in anticipation of higher future income.

Another possibility is that weak financial systems may not help in efficiently intermediating foreign capital. This too could result in the lack of a positive relationship between flows of foreign capital and higher growth. Consistent with the views that foreign capital may not be needed nor be helpful because of weak financial systems, the positive correlation between current account balances and growth turns out to be stronger for the group of countries with less well-developed financial systems. In these countries, the range of profitable investment opportunities, as well as private consumption, for those that experience growth episodes, may be constrained by financial sector impediments, so investment can be financed largely through domestically generated savings.

Excessive reliance on foreign capital may also have harmful consequences. It can lead to currency appreciation and, in some circumstance, overvaluation (a level of the exchange rate that is higher than the level warranted by economic fundamentals). In turn, this could hurt competitiveness and exports in key sectors like manufacturing. Recent analyses of growth episodes suggest that a dynamic manufacturing sector is a key to long-run growth. Thus, reduced reliance on foreign capital--and the avoidance of overvaluation--may help the development of an export-oriented manufacturing sector.

\section{Are Developing Countries Savings-Constrained?}

The results discussed above are consistent with Rodrik's (2007a) view that developing economies are investment-constrained rather than savings-constrained. That is, the conventional notion that access to foreign capital would expand investment opportunities in developing countries does not seem to be borne out by the data. Moreover, when capital inflows lead to exchange rate overvaluation, the net effect on growth can be negative. Rodrik (2007b) goes further, however, to suggest that a systematic policy of keeping the exchange rate undervalued by maintaining a relatively closed capital account and intervening in the foreign exchange market when necessary is good for a developing country's growth. Prasad, Rajan and 
Subramanian (2007) find no evidence in support of this proposition - that is, overvaluation does seem to be bad for growth but it is not obvious that undervaluation is good for growth. ${ }^{52}$

\section{Policy Implications}

What does all this mean for policies toward financial integration? Any discussion of the merits of financial integration is likely to be very specific to a country. These results suggest that - insofar as the domestic financial sector is underdeveloped and there is a need to avoid exchange rate appreciation caused by inflows - greater caution towards certain forms of foreign capital inflows might be warranted. At the same time, financial openness may itself be needed to spur domestic financial development and to reap the benefits that financial flows and better growth opportunities provide.

How can this tension be resolved? One approach might be a firm — and hopefully crediblecommitment to integrate financial markets at a definite future date, thus giving time for the domestic financial system to develop without possible adverse effects from capital inflows, even while giving participants the incentive to prepare for it by suspending the sword of future foreign competition over their heads. A recent example of this is the Chinese approach of trying to spur banking reform by committing to open up their banking sector to foreign competition as part of their obligations for accession to the World Trade Organization. Another possibility is to focus on specific collateral benefits that may be relevant for a particular country and to then try to design an appropriate capital account liberalization program that would deliver that limited set of benefits.

\section{Capital Controls As A Policy Tool}

Although financial flows can potentially lead to long-term growth benefits, heavy capital inflows may pose significant challenges to macroeconomic stability. A key policy question for developing economies is to determine how to effectively manage these large inflows. Capital controls are one of the more controversial choices available to policymakers during periods of large capital flows. Countries employ control measures to attain a variety of policy objectives, such as discouraging capital inflows to reduce upward pressures on the exchange rate, reducing the risk associated with the sudden reversal of inflows, and maintaining some degree of monetary policy independence (Magud and Reinhart, 2007). After a brief overview of the different types of capital controls and their measurement, this section provides a summary of macroeconomic and microeconomic implications of capital controls.

\footnotetext{
${ }^{52}$ Prasad et al. (2007) estimate cross-country growth regressions with separate slopes on the exchange rate valuation variable for countries with overvalued and undervalued exchange rates. They find weak evidence of the asymmetric effect described in the text.
} 


\section{VIII.1. Implementation and Measurement Issues}

Although capital controls cover a wide range of measures regulating inflows and outflows of foreign capital, they generally take two broad forms: direct (or administrative) and indirect (or market-based) controls. Direct controls are associated with administrative measures, such as direct prohibitions and explicit limits on the volume of transactions. For example, Malaysia introduced a set of direct capital controls in 1998 involving various quantitative restrictions on cross-border trade of its currency and credit transactions. Indirect capital controls include explicit or implicit taxation of financial flows and differential exchange rates for capital transactions. For example, in order to discourage capital inflows Chile imposed an implicit tax in 1991 in the form of an unremunerated reserve requirement (URR) on specified inflows for up to one year. These controls were substantially relaxed in 1998 (see Magud and Reinhart, 2007).

Using a variety of capital control measures, a large literature has studied their macroeconomic and microeconomic implications. However, irrespective of their type, it is a challenge to effectively quantify the extent of capital controls as discussed in section II. In particular, it would be desirable to capture the degree of enforcement of capital controls. Moreover, the impact of a measure would depend on a broad assessment of the openness of the capital account.

\section{VIII.2. Macroeconomic Implications of Capital Controls}

The literature assessing whether capital controls have attained their stated macroeconomic objectives is, at best, mixed. ${ }^{53}$ It is hard to draw a set of general results as most of the studies are based on country cases (Ariyoshi and others, 2000). Overall, the studies suggest that controls on inflows did not affect the volume of net flows in most countries, although it seems that they were able to temporarily tilt the composition towards longer maturities in a few cases (Chile after 1991, see Edwards and Rigobon, 2005). ${ }^{54}$ Even in cases where a narrow range of objectives were met, controls had only temporary effects as market participants eventually found ways to circumvent them. Clearly, however, there is a cost to market participants of evading such controls, which effectively acts as a tax on inflows. An open question is whether this tax simply

\footnotetext{
${ }^{53}$ Magud and Reinhart (2007) argue that the literature analyzing the macroeconomic implications of capital controls using aggregate data has only limited value added since the studies in this literature suffer from various problems, including the use of heterogeneous samples, differences in methodologies, and multiple definitions of outcomes associated with the success of controls. Based on a study of the Malaysian experience, Abdelal and Alfaro (2003) argue that countries can rarely control international capital flows by imposing controls.

${ }^{54}$ Moreover, stricter controls on outflows appeared to reduce net capital flows and allow more independent monetary policy in Malaysia after 1998, but there is little support for such outcomes in other countries (Magud and Reinhart, 2007). Kaplan and Rodrik (2001) provide evidence in support of the benefits of capital controls for monetary policy independence in Korea, Thailand, Indonesia and Malaysia.
} 
imposes a distortionary cost without affecting the volume of flows significantly, or if the tax is large enough to reduce flows materially at least in the short run.

Cardarelli, Elekdag and Kose (2007) analyze the effectiveness of capital controls various policy responses in over 100 episodes of large net private capital inflows in a group of emerging market countries and advanced economies since 1987. They find that episodes characterized by tighter controls on inflows are associated with narrower current account deficits and lower net private inflows, including lower net FDI flows (Figure VIII.1). While stricter inflow controls are accompanied by lower-post inflow growth and a larger appreciation of the currency, these distinctions are not statistically significant. In contrast, inflation rates have been significantly higher in episodes with tighter controls.

Does having capital controls in place reduce vulnerability to financial crises and sudden stops? Episodes that ended in an abrupt reversal of net inflows do not seem to be associated with lower capital controls (Figure VIII.2). On the contrary, although the differences are not statistically significant, Cardarelli et al. (2007) report that episodes that ended abruptly were associated with somewhat stricter inflow controls. These findings are consistent with results we document in section III about the smaller likelihood of crises in countries with more open capital account regimes. ${ }^{55}$

\section{VIII.3. Microeconomic Implications of Capital Controls}

Although the literature analyzing the macroeconomic implications of capital controls is unable to produce conclusive evidence, recent studies using micro data find that controls result in significant efficiency costs at the level of individual firms or sectors (see Forbes, 2005a, for a survey). These costs often manifest themselves through indirect channels. For example, capital controls result in an increase in the cost of capital, reduce market discipline, create distortions in the behavior of firms and individuals, and impose substantial administrative costs on the government. There is also some recent evidence suggesting that capital controls involving exchange rate transactions act as non-tariff trade barriers reducing the volume of trade flows.

\section{Higher cost of capital}

Some recent studies argue that the Chilean capital controls increased financial constraints for smaller firms by making it more difficult and expensive for them to raise capital (Forbes, 2005b).

\footnotetext{
${ }^{55}$ Another policy used by some countries to cope with large net inflows was the removal of controls on outflows. Evidence based on the wave of inflows during the 1990s suggests that elimination of controls on outflows has often led to larger inflows. In a recent paper, Aizenman and Noy (2006) report that controls on capital account transactions have no impact on the volume of flows. Liberalizing outflow restrictions may attract heavier inflows by sending a positive signal to markets increasing investor confidence, and thereby fuelling even larger inflows (Bartolini and Drazen, 1997), which is supported by evidence based on several countries (Reinhart and Reinhart, 1998).
} 
The cost of capital is higher for multinationals as well when controls are in place (Desai, Foley and Hines, 2004). For example, multinational affiliates located in countries with capital controls are found to face interest rates that are about 5 percentage points higher than affiliates of the same parent company borrowing locally in countries without capital controls. The wedge arises because capital controls typically result in costs of avoidance of those controls as well as higher domestic interest rates. The cross-country investment patterns of multinationals suggest that the level of FDI inflows into a country is adversely affected by capital controls because of their impact on the cost of capital.

\section{Reduced market discipline}

By insulating the economy from competitive forces, capital controls reduced market discipline among Malaysian firms and created a screen for cronyism (Johnson and Mitton, 2002). The cost of these controls was quite significant because the ability of the government to provide subsidies to politically connected firms increased with the imposition of controls.

\section{Distortions in firm/individual behavior and cost on government}

Capital controls can cause distortions in the behavior of firms (and individuals) with the objective of evading the controls. For example, when the Argentine government imposed capital controls at the end of 2001, in order to evade the controls investors came up with a variety of schemes leading to a large volume of capital outflow. ${ }^{56}$ Since the controls often have to be continually updated in order to close loopholes and limit evasion, they involve significant administrative and monitoring costs (Forbes, 2005a).

\section{Controls as non-tariff barriers}

In countries with extensive capital controls, firms and individuals often try to circumvent them by mis-invoicing imports and exports or both. In response, authorities have to implement various inspections and impose extensive reporting requirements to minimize such leakages. These increase the cost of engaging in international trade even for those firms that do not intend to evade capital controls (Wei and Zhang, 2006). Such controls have economically and statistically significant negative effects on the volume of trade. For example, a one standard deviation increase in the controls on foreign exchange transactions reduces trade by the same amount as a rise in tariff by 10.8 to 11.3 percentage points.

While policymakers aim at moderating the volume and/or volatility of certain types of capital flows with the help of these controls, evidence presented in this section suggests that their macroeconomic impact has been temporary at best. Moreover, evidence indicates that they have been associated with substantial microeconomic costs.

\footnotetext{
${ }^{56}$ In particular, investors evaded them by purchasing Argentine stocks for pesos, converting the stocks into ADRs, and then selling the ADRs in New York for dollars that could be deposited in U.S. bank accounts.
} 


\section{How To Approach Financial Integration?}

A number of papers have attempted to reconcile the disparity between theory and empirical evidence on the benefits of financial globalization by suggesting that the costs - including crises - are in the nature of growing pains that will recede once globalizing economies achieve fuller integration..$^{57}$ This finding partly lines up with the results about financial integration generating collateral benefits and thereby eventually having a positive impact on economic growth. Similarly, Martinez, Tornell and Westermann (2004) argue that crises are the price that must be paid to attain rapid growth in the presence of contract enforceability problems. These authors present some evidence that developing economies that have registered higher growth rates have typically experienced boom-bust cycles (also see Kaminsky and Schmukler, 2003, and Bussiere and Fratzscher, 2004).

These papers reflect the notion that financial globalization carries a short-run cost - one that must inevitably be paid if a developing country, which typically has weak institutions and a fragile financial sector, wants to move on to a high-growth path. And, putting this together with the literature that finds that financial globalization could serve as a useful catalyst for improving domestic institutions and financial markets, it appears that developing countries face a Hobson's choice. Globalize and improve growth prospects at a cost of vulnerability to painful crises. Or not globalize and bear the cost of being stuck in a low-growth environment. Is there a way out? ${ }^{58}$

The reality is that developing economies may ultimately have little choice but to accept financial globalization since staying closed could become increasingly costly in terms of foregone longterm economic welfare, both in absolute and relative terms. There are some approaches that countries could adopt to try and acquire some of the benefits of globalization, say by opening up to trade flows and liberalizing trade-related capital account transactions. Trade integration may deliver some of the benefits of globalization, including preparing the ground for financial

\footnotetext{
${ }^{57}$ For instance, Krugman (2002) has argued that “...growing integration does predispose the world economy toward more crises, mainly because it creates pressures on governments to relax financial restrictions that in earlier decades made 1990s-style financial crises much less likely." He goes on to say that "In the long run, integration may solve the problems it initially creates."

${ }^{58}$ Rodrik (2007a) emphasizes the importance of creating an efficient "policy space" that could help address the risks associated with trade and financial integration. Hausmann, Rodrik and Velasco (2005) argue that it is critical to identify the major constraint(s) that hamper economic growth and then propose solutions to eliminate them. Based on this idea, they develop a methodology of "growth diagnostics". In light of the results of these diagnostics, Rodrik (2004) concludes that industrial policies, which are partly shaped by public institutions, play an important role in promoting economic development. Aghion and Durlauf (2007) criticize this approach and advance an alternative one based on standard growth regressions. Zettelmeyer (2006) provides a brief evaluation of the growth diagnostics approach in the context of the Latin American experience.
} 
integration. But this has its limits since trade integration creates channels for de facto financial integration.

The collateral benefits perspective proposed in this chapter does suggest a way for moving forward on capital account liberalization, if policymakers in a given country feel that it could be beneficial but are concerned about the attendant risks. If one can identify which reform priorities are the key ones for a particular country, then one can design an approach to capital account liberalization that could generate specific benefits while minimizing the associated risks. For instance, Prasad and Rajan (2008) propose an approach to controlled capital account liberalization for economies trying to manage their exchange rates while experiencing large inflows. Their approach, which would essentially involve securitizing inflows via private mutual funds that would invest abroad, would generate benefits such as development of domestic financial markets (through the issuance and trading of securities) and would also give domestic agents access to international portfolio diversification opportunities. But the outflows would be controlled both in terms of quantity and timing, thereby reducing the risks. This could mitigate the problem noted by Bhagwati (1998) that, once opened, capital accounts can subsequently be difficult to close even if circumstances should warrant it. ${ }^{59}$

\section{Conclusion}

Our synthesis of the literature on financial globalization and economic policies points to some major complications during the transition from low to high levels of financial integration. Financial globalization can in principle play a catalytic role in generating an array of collateral benefits that boost long-run growth and welfare. These collateral benefits could include development of the domestic financial sector, improvements in institutions and better macroeconomic policies. By contrast, the macroeconomic evidence on the benefits and effectiveness of capital controls is at best mixed while some recent studies based on firm-level data indicate that controls appear to lead to various costs at the micro level. The implications of these results for policies towards capital account liberalization are complicated by the existence of threshold conditions. Full-fledged opening of the capital account in the absence of essential supporting conditions can vitiate the realization of any benefits, while making a country more vulnerable to sudden stops of capital flows. Economic policies designed to foster these necessary

\footnotetext{
${ }^{59}$ Some recent papers reach opposite conclusions about the nature of policy responses to financial integration. For example, Rodrik and Subramanian (2008) conclude that the benefits of financial globalization are hard to document and it would be useful to consider policies to restrict capital inflows, if country specific conditions deserve such a response. In contrast, Mishkin (2008) argues that, in order to attain better standards of living, emerging market economies need to become more integrated with the global financial system while employing policies that can improve their institutional frameworks to facilitate the growth and stability enhancing effects of international financial flows.
} 
supporting conditions, while beneficial in their own right, could also be instrumental in more effectively utilizing the growth and stability gains stemming from financial integration.

We obviously do not have a silver bullet to offer based on our reading of the literature as our analysis suggests that the relationship between financial integration and economic policies is a complex one and that there are inescapable tensions inherent in evaluating the risks and benefits associated with financial globalization. Although there is evidence in support of our broad conclusions, even these often need to be tailored to take into account country specific circumstances in light of these tensions. Nevertheless, it is essential to see financial integration not just as an isolated policy goal but as part of a broader package of reforms and supportive macroeconomic policies.

It is becoming increasingly more sensible for developing countries to shift their focus to how they will manage the process of financial liberalization rather than whether they should liberalize at all (see Prasad, 2008, for a discussion in the context of India). There are at least a couple of compelling reasons for this: First, capital accounts will become more open so long as there are strong incentives for cross-border flows of capital. Increasing global financial flows will inevitably result in de facto opening of the capital account, irrespective of the capital control regime. Hence, it may be best for policymakers in emerging market economies to take steps to actively manage the process of financial integration — rather than just try to delay or push back against the inevitable - in order to improve the benefit-cost tradeoff. Otherwise, policymakers may be stuck with the worst of all possible worlds - the distortions created by de jure capital controls and the complications of domestic macroeconomic management that are a consequence of increasing cross-border flows.

Second, given the balance of risks will vary over time, the global economic environment and the circumstances of individual countries may create windows of opportunity for countries to pursue financial integration. For instance, private capital flows in the last few years are increasingly taking the form of FDI or portfolio equity flows, both of which are less volatile and more beneficial than portfolio debt flows. A number of emerging market economies have accumulated large stocks of foreign exchange reserves, and have also become more open to trade, which has substantially reduced the risks related to sudden stops or reversals of capital inflows, and also mitigated risks of contagion. A country that has shifted the terms of the debate to "how" from "whether" can take advantage of these windows of opportunity to press for further liberalization.

Our findings suggest that, in exploring appropriate policies with respect to the liberalization of financial account, policy makers need to consider not only the relevant threshold conditions, but also the collateral benefits associated with integration. In light of this conclusion, how can policymakers approach the process of capital account liberalization? The collateral benefits perspective suggests a way for moving forward on capital account liberalization. If one can identify which reform priorities are the key ones for a particular country, then one can design a controlled approach to liberalization that could generate specific benefits while minimizing the associated risks. This is preferable to a complete opening of the capital account, which could also deliver that benefit, but at the cost of the possibility of worsening the benefit-risk tradeoff of 
financial opening. This approach also provides a broader analytical framework within which one can incorporate country-specific features and initial conditions into the design of appropriate capital account liberalization programs.

None of this is to say that the design of an analytical framework is easy, or that the risks of financial integration are small, and that countries should rush headlong into it. Indeed, one of the main lessons of recent episodes of capital account liberalization is that, once the taps are opened to capital flows, it can be very difficult to shut them off. Moreover, allowing financial integration to get too far ahead of other policy reforms - especially domestic financial sector reforms and greater exchange rate flexibility — could have potentially devastating consequences if there were to be sudden shifts in international investor sentiment. There are also substantial inefficiencies in international financial markets, which remain far from complete in terms of the range of available instruments for sharing risk and are still beset by informational asymmetries, herding behavior and other such pathologies. ${ }^{60}$

Where can research help sharpen such policy conclusions? First, it is imperative to extend the research program on measuring financial openness. Although it is clear that different countries have adopted widely differing approaches to financial globalization, existing measures of crosscountry differences are so crude that it is difficult to evaluate the macroeconomic outcomes of various policies in many cases.

Future research should focus on the indirect benefits of financial globalization that ultimately express themselves in productivity growth and macroeconomic stability. Early research that emphasized how financial globalization can help enhance physical capital accumulation in developing countries was clearly misplaced. The links between certain aspects of open capital accounts (e.g., unrestricted foreign bank entry) and domestic financial sector development have been analyzed extensively, but evidence on other indirect benefits is limited. Future studies on these issues would help understand the quantitative impact of various indirect channels associated with financial globalization and can potentially lead to a better framework in evaluating alternative policies.

Another promising research avenue is a more detailed analysis of threshold effects - especially the relative importance of different threshold conditions and the tradeoffs among them for a country that wishes to open up its capital account. How to balance the risks stemming from the absence of certain supporting conditions against the collateral benefits to be gained from

\footnotetext{
${ }^{60}$ For instance, as we discussed, efficient international risk sharing could yield enormous welfare gains, especially for developing countries, which have more volatile GDP growth rates than industrial countries. But, the degree of international risk sharing remains limited, mainly for want of suitable instruments. Despite the allure of GDP-indexed bonds as a device for sharing risk among countries, their use remains very limited. Griffith-Jones and Sharma (2006) discuss the potential benefits of such instruments and the factors that have limited their prevalence so far.
} 
financial integration is a pressing policy question. Future research needs to focus on the design of a unified framework for analyzing a variety of thresholds and their implications for the process of financial integration.

Our findings also suggest that it is difficult to make strong statements about the potential role of economic policies in shaping the growth and stability outcomes of financial integration using macroeconomic data. Further research based on industry- and firm-level data as well as event and case studies may provide more informative insights about the design of economic policies that could improve the benefits of financial integration. 


\section{References}

Abdelal, R., Alfarol, L. (2003). "Capital and control: lessons from Malaysia". Challenge 46(4), 36-53.

Acemoglu, D., Johnson, S., Robinson, J. A. (2001). "The colonial origins of comparative development: an empirical investigation”. American Economic Review 91(5), 13691401.

—, Thaicharoen, Y. (2003). "Institutional causes, macroeconomic symptoms: volatility, crises and growth". Journal of Monetary Economics 50(1), 49-123.

Aghion, P., Bacchetta, P., Banerjee, A. (2004). "Financial development and the instability of open economies". Journal of Monetary Economics 51(6), 1077-1106.

Aghion, P., Banerjee, A. (2005). Volatility and Growth: Clarendon Lectures in Economics. Oxford University Press, New York.

Aghion, P., Durlauf, S. (2007). "From growth theory to policy design". Working Paper, Harvard University.

Aitken, B. J., Harrison, A. E. (1999). "Do domestic firms benefit from direct foreign investment? Evidence from Venezuela”. American Economic Review 89(3), 605-618.

Aizenman, J., Noy, I. (2008). "Links between trade and finance - a disaggregated analysis". In: Edwards, S., Garcia, M. G. P. (Eds.), Financial Markets Volatility and Performance in Emerging Markets, National Bureau of Economic Research Conference Report. University of Chicago Press, Chicago.

Aizenman, J., Pinto, B. (Eds.) (2006). Managing Economic Volatility and Crisis. Cambridge University Press, New York.

Akin, C., Kose, M. A. (2008). "Changing nature of north-south linkages: stylized facts and explanations". Journal of Asian Economics 19 (1), 1-28.

Albuquerque, R. (2003). "The composition of international capital flows: risk sharing through foreign direct investment”. Journal of International Economics 61(2), 353-383.

Alfaro, L., Chanda, A., Kalemli-Ozcan, S., Sayek, S. (2004). "FDI and economic growth: the role of local financial markets". Journal of International Economics 64(1), 89-112.

Alfaro, L., Hammel, E. (2007). “Capital flows and capital goods”. Journal of International Economics 72(1), 128-150.

Alfaro, L., Kalemli-Ozcan, S., Volosovych, V. (2007). "Capital flows in a globalized world: the role of policies and institutions". In: Edwards, S. (Ed.), Capital Controls and Capital Flows in Emerging Economies: Policies, Practices, and Consequences, National Bureau of Economic Research Conference Report. University of Chicago Press, Chicago.

Aoki, K., Benigno, G., Kiyotaki, N. (2007). “Adjusting to capital account liberalization”. Working Paper, London School of Economics.

Ariyoshi, A., Habermeier, K., Laurens, B., Otker-Robe, I., Canales-Kriljenko, J.I., Kirilenko, A. (2000). "Capital controls: country experiences with their use and liberalization". IMF Occasional Paper 190. International Monetary Fund, Washington. 
Arteta, C., Eichengreen, B., Wyplosz, C. (2003). "When does capital account liberalization help more than it hurts?" In: Helpman, E., Sadka, E. (Eds.), Economic Policy in the International Economy: Essays in Honor of Assaf Razin. Cambridge University Press, Cambridge, UK.

Balasubramanyam, V.N., Salisu, M., and Sapsford, D. (1996). "Foreign direct investment and growth in EP and IS countries". Economic Journal 106(434), 92-105.

Baltagi, B., Demetriades, P., Law, S. H. (2007). "Financial development, openness and institutions: evidence from panel data". Working Paper, Syracuse University.

Bartolini, L., Drazen, A. (1997). "Capital-account liberalization as a signal”. American Economic Review 87(1), 138-154.

Beck, T., Lundberg, M., Majnoni, G. (2001). "Financial intermediary development and growth volatility: do intermediaries dampen or magnify shocks?” Journal of International Money and Finance 25(7), 1146-1167.

Bekaert, G., and Harvey, C. R. (2000). "Foreign speculators and emerging equity markets". Journal of Finance 55(2), 565-613.

_ L Lundblad, C. (2005). “Does financial liberalization spur growth?” Journal of Financial Economics 77(1), 3-55.

_ (2006) "Growth volatility and equity market liberalization". Journal of International Money and Finance 25(3), 370-403.

Berg, A., Borensztein, E., Pattillo C. (2004). "Assessing early warning systems: how have they worked in practice?” IMF Working Paper 04/52. International Monetary Fund, Washington.

Bhagwati, J. (1998). "The capital myth. The difference between trade in widgets and dollars". Foreign Affairs 7(3), 7-12.

Bonfiglioli, A. (2008). "Financial integration, productivity and capital accumulation". Forthcoming in Journal of Intertnational Economics.

— Mendicino, C. (2004). "Financial liberalization, banking crises, and growth: assessing the links". Working Paper Series in Economics and Finance 567, Stockholm School of Economics.

Bordo, M., Taylor, A. M., Williamson, J. G. (2003). Globalization in Historical Perspective, National Bureau of Economic Research Conference Report. University of Chicago Press, Chicago.

Brecher, R. A., Diaz-Alejandro, C. F. (1977). "Tariffs, foreign capital, and immiserizing growth”. Journal of International Economics 7, 317-322.

Buch, C. M., Döpke, J., Pierdzioch, C. (2005). "Financial openness and business cycle volatility". Journal of International Money and Finance 24, 744-765.

Bussiere, M., Fratzscher, M. (2004). "Financial openness and growth: short-run gain, long-run pain?” ECB Working Paper No. 348. 
Caballero, R., Farhi, E., Gourinchas, P. O. (2006). “An equilibrium model of "global imbalances" and low interest rates". NBER Working Papers 11996, National Bureau of Economic Research, Cambridge, MA.

Caballero, R. J., Krishnamurthy, A. (2001). "International and domestic collateral constraints in a model of emerging market crises". Journal of Monetary Economics 48(3), 513-548.

Calvo, G., Izquierdo, A., Mejía, L. F. (2004). "On the empirics of sudden stops: the relevance of balance-sheet effects". Federal Reserve Bank of San Francisco Proceedings, June.

Calvo, G., Leiderman, L., Reinhart, C. M. (1994). "The capital inflows problem: concepts and issues". Contemporary Economic Policy 12(3), 54-66.

Calvo, G., Talvi, E. (2005). "Sudden stop, financial factors, and economic collapse in Latin America: learning from Argentina and Chile". NBER Working Papers 11153, National Bureau of Economic Research, Cambridge, MA.

Cardarelli, R., Elekdag, S., Kose, M. A. (2007). "Managing Large Capital Flows". World Economic Outlook, October, 105-134, International Monetary Fund, Washington.

Carkovic, M., Levine, R. (2005). "Does foreign direct investment accelerate economic growth?" In: Moran, T. H., Graham, E. M., Blomström, M. (Eds), Does Foreign Investment Promote Development?, 195-220. Institute for International Economics, Washington.

Cavallo, E. A. (2007). "Output volatility and openness to trade: a reassessment". RES Working Papers 4518. Inter-American Development Bank, Research Department, Washington.

Chanda, A. (2005) "The influence of capital controls on long run growth: where and how much?” Journal of Development Economics 77, 441-466.

Chari, A., Henry, P. B. (2004). "Risk sharing and asset prices: evidence from a natural experiment". Journal of Finance 59(3), 1295-1324. . (2008). "Firm-specific information and the efficiency of investment". Journal of Financial Economics 87(3), 636-655.

Chinn, M. Ito, H. (2006). "What matters for financial development? Capital controls, institutions and interactions". Journal of Development Economics, 81(1), 163-192.

Claessens, S., Demirgüç-Kunt, A., Huizinga, H. (2001). "How does foreign entry affect domestic banking markets?" Journal of Banking and Finance 25(5), 891-911.

Claessens, S., Laeven, L. (2004). "What drives bank competition? Some international evidence". Journal of Money, Credit, and Banking 36(3), 563-583.

Clarke, G., Cull, R., Martinez Peria M. S., Sanchez, S. M. (2003). "Foreign bank entry: experience, implications for developing economies, and agenda for further research". World Bank Research Observer 18(1), 25-59.

Collins, S. M. (2007)“Comments on "Financial globalization, growth, and volatility in developing countries" by Eswar Prasad, Kenneth Rogoff, Shang-Jin Wei, and M. Ayhan Kose". In: Harrison, A. (Ed.), Globalization and Poverty, National Bureau of Economic Research Conference Report. University of Chicago Press, Chicago.

Cornelius, P. K., Kogut, B. (Eds.) (2003). Corporate Governance and Capital Flows in a Global Economy. Oxford University Press, New York. 
Denizer, C., Iyigun, M. F., Owen, A. L. (2002). "Finance and macroeconomic volatility". Contributions to Macroeconomics 2(1), Article 7.

Desai, M. A., Foley, C. F., Hines, J. R. Jr. (2004). "Capital controls, liberalizations and foreign direct investment”. NBER Working Papers 10337, National Bureau of Economic Research, Cambridge, MA.

Desai, P. (2003). Financial Crisis, Contagion, and Containment: From Asia to Argentina. Princeton University Press, Princeton.

Desai, P., Mitra, P. (2004). "Why do some countries recover more readily from financial crises?" Paper presented at the IMF Conference in honor of Guillermo A. Calvo. International Monetary Fund, Washington.

Doidge, C., Karolyi, A., Stulz, R. (2005). "Why do countries matter so much for corporate governance?” Journal of Financial Economics 86(1), 1-39.

Durham, J. B. (2004). "Absorptive capacity and the effects of foreign direct investment and equity foreign portfolio investment on economic growth". European Economic Review 48(2), 285-306.

Easterly, W., Islam, R., Stiglitz, J. E. (2001). "Shaken and stirred: explaining growth volatility". In: Pleskovic, B., Stern, N. (Eds.), Annual World Bank Conference on Development Economics. World Bank, Washington.

Edison, H. J., Klein, M., Ricci, L., Sløk, T. (2004). “Capital account liberalization and economic performance: survey and synthesis”. IMF Staff Papers 51(2). International Monetary Fund, Washington.

Edison, H. J., Levine, R., Ricci, L., Sløk, T. (2002). "International financial integration and economic growth". Journal of International Monetary and Finance 21(6), 749-776.

Edison, H. J., Warnock, F. E. (2003). “A simple measure of the intensity of capital controls”. Journal of Empirical Finance 10(1-2), 81-103.

Edwards, S. (ed.) (2000) Capital Flows and the Emerging Economies: Theory, Evidence, and Controversies, National Bureau of Economic Research Conference Report. University of Chicago Press, Chicago.

. (2001). "Capital mobility and economic performance: are emerging economies different?” NBER Working Papers 8076, National Bureau of Economic Research, Cambridge, MA.

- (2004). "Financial openness, sudden stops, and current account reversals". NBER Working Papers 10277, National Bureau of Economic Research, Cambridge, MA. - (2005). "Capital controls, sudden stops, and current account reversals.” NBER Working Papers 11170, National Bureau of Economic Research, Cambridge, MA.

. (2008). "Financial openness, currency crises and output losses". In: Edwards, S., Garcia, M. G. P. (Eds.), Financial Markets Volatility and Performance in Emerging Markets, National Bureau of Economic Research Conference Report. University of Chicago Press, Chicago. 
—, Rigobon, R. (2005). “Capital controls, exchange rate volatility and external vulnerability”. NBER Working Papers 11434, National Bureau of Economic Research, Cambridge, MA.

Eichengreen, B. J. (2000). “Taming capital flows”. World Development 28(6), 1105-1116.

. (2001). "Capital account liberalization: what do cross-country studies tell us?" World Bank Economic Review (15), 341-65.

—, Hausmann, R., Panizza, U. (2006). "The pain of original sin”. In: Eichengreen, B., Hausmann, R. (Eds.), Other People's Money. University of Chicago Press, Chicago.

Eichengreen, B., Rose. A., Wyplosz, C. (1995). "Exchange market mayhem: the antecedents and aftermath of speculative attacks". Economic Policy 10(21), 249-312.

Eozenou, P. (2006). "Financial integration and macroeconomic volatility: does financial development matter?” Working Paper, European University Institute.

Faria, A., Mauro, P. (2005). "Institutions and the external capital structure of countries". IMF Working Paper 04/236. International Monetary Fund, Washington.

Fernandez-Arias, E., Montiel, P. J. (1996) "The surge in capital inflows to developing countries: an overview". World Bank Economic Review 10(1), 51-77.

Fischer, S. (1998). "Capital account liberalization and the role of the IMF”. In: Should the IMF Pursue Capital-Account Convertibility?, Princeton Essays in International Finance 207, 1-10, Princeton University Press, Princeton.

Forbes, K. (2005a). "The microeconomic evidence on capital controls: no free lunch". NBER Working Papers 11372. National Bureau of Economic Research, Cambridge, MA.

_. (2005b). "Capital controls: mud in the wheels of market efficiency". Cato Journal 25(1).

Frankel, J. (1992). "Measuring international capital mobility: a review”. American Economic Review 82(2), 197-202.

- Cavallo, E. A. (2004). "Does openness to trade make countries more vulnerable to sudden stops or less? Using gravity to establish causality”. NBER Working Papers 10957. National Bureau of Economic Research, Cambridge, MA.

Frankel, J., Rose, A. K. (1996). "Currency crashes in emerging markets: an empirical treatment". Journal of International Economics 41(3-4), 351-366.

Frankel, J., Wei, S. J. (2005). “Managing macroeconomic crises: policy lessons”. In: Aizenman, J., Pinto, B. (Eds), Managing Economic Volatility and Crises: A Practitioner's Guide. Cambridge University Press, New York.

Gelos, R. G., Wei, S. J. (2005). “Transparency and international portfolio holdings". Journal of Finance 60(6), 2987-3020.

Gertler, M., Rogoff, K. (1990). "North-South lending and endogenous domestic capital market inefficiencies". Journal of Monetary Economics 26(2), 245-266.

Ghosh, A., Gulde, A. M., Wolf, H. (2003). Exchange Rate Regimes: Choices and Consequences. MIT Press, Cambridge, MA. 
Glick, R. (ed.) (1998). Managing Capital Flows and Exchange Rates: Perspectives from the Pacific Basin. Cambridge University Press, Cambridge, MA.

- Guo, X., Hutchison, M. (2006). "Currency crises, capital-account liberalization, and selection bias". Review of Economics and Statistics 88(4), 698-714.

Glick, R., Hutchison, M. (2001). "Banking and currency crises: how common are twins?” In: Glick, R., Moreno, R., Spiegel, M. M. (Eds.), Financial Crises in Emerging Markets. Cambridge University Press, New York.

Gordon, R., Bovenberg, A. L. (1996). "Why is capital so immobile internationally? Possible explanations and implications for capital income taxation". American Economic Review 86(5), 1057-75.

Gourinchas, P. O., Jeanne, O. (2005). “Capital mobility and reform”. IMF Manuscript. International Monetary Fund, Washington.

- (2006). "The elusive gains from international financial integration”. Review of Economic Studies 73(3), 715-741.

Goldberg, Linda. (2008). “Understanding Banking Sector Globalization”. Forthcoming in IMF Staff Papers.

Griffith-Jones, S., Sharma, K. (2006). “GDP-indexed bonds: making it happen”. DESA Working Paper 21, United Nations.

Grilli, V., Milesi-Ferretti, G. M. (1995). "Economic effects and structural determinants of capital controls”. IMF Staff Papers 42(3), 517-551. International Monetary Fund, Washington.

Guidotti, P. E., Sturzenegger, F., Villar, A. (2004). "On the consequences of sudden stops". Economía 4(2), 171-214.

Gupta, N., Yuan, K. (2008). "On the growth effects of liberalizations”. Forthcoming in Review of Financial Studies.

Haddad, M., Harrison, A. (1993). “Are there positive spillovers from direct foreign investment? Evidence from panel data for morocco". Journal of Development Economics 42(1), 5174.

Hall, R. E., Jones, C. I. (1999). "Why do some countries produce so much more output per worker than others?" The Quarterly Journal of Economics 114(1), 83-116.

Hammel, E. (2006). "Stock market liberalization and industry growth". Manuscript, Harvard Business School.

Hausmann, R., Fernández-Arias, E. (2000). "Foreign direct investment: good cholesterol?" IADB Working Paper 417. Inter-American Development Bank, Washington.

Hausmann, R., Rodrik, D., Velasco, A. (2008). “Growth diagnostics”. In: Stiglitz, J., Serra, N. (Eds.), The Washington Consensus Reconsidered: Towards a New Global Governance. Oxford University Press, New York.

Henry, P. B. (2000a). "Stock market liberalization, economic reform, and emerging market equity prices". Journal of Finance 55(2), 529-564. 
. (2000b). "Do stock market liberalizations cause investment booms?" Journal of Financial Economics 58(1-2), 301-334.

- (2007). "Capital account liberalization: theory, evidence, and speculation". Journal of Economic Literature 45(4), 887-935.

Hermes, N., Lensink, R. (2003). "Foreign direct investment, financial development and economic growth". Journal of Development Studies 40(1), 142-163.

Hines, J. R. Jr. (1995). “Forbidden payment: foreign bribery and American business after 1977”. NBER Working Papers 5266. National Bureau of Economic Research, Cambridge, MA.

Husain, A., Moday, A., Rogoff, K. (2005). "Exchange rate regime durability and performance in developing versus advanced economies". Journal of Monetary Economics 52(1), 35-64.

Hutchinson, M., Noy, I. (2005). "How bad are the Twins? Output costs of currency and banking crises". Journal of Money, Credit and Banking 37(4), 725-752.

Imbs, J. (2006). “The real effects of financial integration". Journal of International Economics 68(2), 296-324.

International Monetary Fund. (2007). "Reaping the benefits of financial globalization". Policy Discussion Paper. International Monetary Fund, Washington.

Ishii, S., Habermeier, K., Laurens, B., Leimone, J., Vadasz, Canales-Kriljenko, J. I. (2002).

"Capital account liberalization and financial sector stability". IMF Occasional Paper 211. International Monetary Fund, Washington.

Javorcik, B. S. (2004). "Does foreign direct investment increase the productivity of domestic firms? In search of spillovers through backward linkages". American Economic Review 94(3), 605-627.

Johnson, S., Mitton, T. (2003). "Cronyism and capital controls: evidence from Malaysia". Journal of Financial Economics 67(2), 351-382.

Jones, B. F., Olken, B. A. (2005). "Do leaders matter? National leadership and growth since World War II". The Quarterly Journal of Economics 120(3), 835-864.

Ju, J.m Wei, S. J. (2006). "A solution to two paradoxes of international capital flows". NBER Working Papers 12668. National Bureau of Economic Research, Cambridge, MA.

Kaminsky, G. L., Reinhart, C. M., Vegh, C. A. (2004). "When it rains, it pours: procyclical capital flows and macroeconomic policies". NBER Working Papers 10780. National Bureau of Economic Research, Cambridge, MA.

Kaminsky, G. L., Schmukler, S. (2003). "Short-run pain, long-run gain: the effects of financial liberalization”. NBER Working Papers 9787. National Bureau of Economic Research, Cambridge, MA.

Kaplan, E., Rodrik, D. (2001). "Did the Malaysian capital controls works?” NBER Working Papers 8142. National Bureau of Economic Research, Cambridge, MA.

Karolyi, G. A., Stulz, R. M. (2003). “Are financial assets priced locally or globally?” In: Constantinides, G. M., Harris, M., Stulz, R. M. (Eds.), Handbook of the Economics of Finance, Financial Markets and Asset Pricing, vol. 1B. Elsevier, Amsterdam. 
Kaufmann, D., Kraay, A., Mastruzzi, M. (2003). "Governance matters III: governance indicators for 1996-2002”. World Bank Policy Research Working Paper 3106. World Bank, Washington.

Kim, E. H., Singal, V. (2000). "Stock market openings: experience of emerging economies". Journal of Business 73(1), 25-66.

Klein, M. (2005). "Capital account liberalization, institutional quality and economic growth: theory and evidence". NBER Working Papers 11112. National Bureau of Economics Research, Cambridge, MA.

, Olivei, G. (2006). "Capital account liberalization, financial depth, and economic growth”. Working Paper, Tufts University.

Kose, M. A., Meredith, G., Towe, C. (2005). "How has NAFTA affected the Mexican economy? Review and evidence”. In: Langhammer, R. J., Vinhas de Souza, L. (Eds.), Monetary Policy and Macroeconomic Stabilization in Latin America, 35-81. Springer-Verlag, New York.

Kose, M. A., Prasad, E. S., Rogoff, K., Wei, S. J. (2006). "Financial globalization: a reappraisal". IMF Working Paper 06/189. International Monetary Fund, Washington. Forthcoming in IMF Staff Papers.

Kose, M. A., Prasad, E. S., Taylor, A. (2008). "Thresholds in the process of international financial integration”. Manuscript, IMF and Cornell University.

Kose, M. A., Otrok, C., and Whiteman, C. (2008). "Understanding the evolution of world business cycles". Journal of International Economics, 75, 110-30.

Kose, M. A., Otrok, C., and Prasad, E. S. (2008). "Global business cycles: convergence or decoupling?” IMF Working Paper No: 08/143.

Kose, M. A., Prasad, E. S., Terrones, M. E. (2003a) "How does globalization affect the synchronization of business cycles?” American Economic Review 93(2), 57-63. . (2003b). "Financial integration and macroeconomic volatility". IMF Staff Papers 50, 119-142.

. (2004). "Volatility and comovement in a globalized world economy: an empirical exploration". In: Siebert, H. (Ed.), Macroeconomic Policies in the World Economy, 89122. Springer-Verlag, New York.

. (2005). "Growth and volatility in an era of globalization". IMF Staff Papers 52, 31-63. International Monetary Fund, Washington.

- (2006). "How do trade and financial integration affect the relationship between growth and volatility?" Journal of International Economics 69, 176-202.

- (2008a). "Does openness to international financial flows raise productivity growth?"

Forthcoming in Journal of International Money and Finance.

. (2008b). "Does financial globalization promote risk sharing?" Forthcoming in Journal of Development Economics.

Kraay, A. (1998). "In search of the macroeconomic effects of capital account liberalization". Manuscript, World Bank (unpublished). 
Krueger, A. O. (2002). "Why crony capitalism is bad for economic growth". In: Haber, S. (Ed.), Crony Capitalism and Economic Growth in Latin America: Theory and Evidence. Hoover Institution Press, Stanford.

Krugman, P. (2002). “Crises: the price of globalization?” Paper presented at 2000 Symposium on Global Economic Integration, Federal Reserve Bank of Kansas City.

Lane, P. R., Milesi-Ferretti, G. M. (2006). "The external wealth of nations mark II: revised and extended estimates of foreign assets and liabilities, 1970-2004". IMF Working Paper 06/69. International Monetary Fund, Washington.

Larrain, B. (2004). "Financial development, financial constraints, and the volatility of industrial output”. Public Policy Discussion Paper 04-6. Federal Reserve Bank of Boston

Leblebicioglu, A. (2006). "Financial integration, credit market imperfections and consumption smoothing". Working Paper, North Carolina State University.

Levchenko, A. A. (2005). "Financial liberalization and consumption volatility in developing countries". IMF Staff Papers 52(2). International Monetary Fund, Washington.

Levine, R. (2001). “International financial integration and economic growth". Review of International Economics 9(4), 684-698.

. (2005). "Finance and growth: theory and evidence". In: Aghion, P., Durlauf, S. (Eds.), Handbook of Economic Growth, vol. 1A, 865-934. Elsevier, Amsterdam.

_ Zervos, S. (1998). “Capital control liberalization and stock market development”. World Development 26(7), 1169-1183.

Levine, R., Schmukler, S. (2006). "Internationalization and stock market liquidity". Review of Finance 10(1), 153-187.

Levy Yeyati, E., Micco, A. (2007). "Concentration and foreign penetration in Latin American banking sectors: impact on competition and risk". Journal of Banking and Finance 31(6), 1633-1647.

Levy Yeyati, E., Sturzenegger, F. (2009). "The effect of monetary and exchange rate policies on development”. In: Rodrik, D., Rosenzweig, M. (Eds.), Handbook of Development Economics, forthcoming. Elsevier, Amsterdam.

Lewis, K. K. (1999). "Trying to explain home bias in equities and consumption". Journal of Economic Literature 37(2), 571-608.

Lipsey, R. E. (2004). "Home and host country effects of FDI". In: Baldwin, R. E., Winters L. A. (Eds.), Challenges to Globalization: Analyzing the Economics, National Bureau of Economic Research Conference Report. University of Chicago Press, Chicago.

Lucas, R. E. Jr. (1990). "Why doesn't capital flow from rich to poor countries". American Economic Review 80(2), 92-96.

Magud, N., Reinhart, C. (2007). "Capital controls: an evaluation”. In: Edwards, S. (Ed.), Capital Controls and Capital Flows in Emerging Economies: Policies, Practices, and Consequences, National Bureau of Economic Research Conference Report. University of Chicago Press, Chicago. 
Martin, P., Rey, H. (2006). "Globalization and emerging markets: with or without crash?” American Economics Review 96(5), 1631-1651.

Martinez, L., Tornell, A., Westermann, F. (2004). "The positive link between financial liberalization growth and crises”. NBER Working Papers 10293. National Bureau of Economic Research, Cambridge, MA.

Mauro, P., Sussman, N., Yafeh, Y. (2006). Emerging Markets, Sovereign Debt, and International Financial Integration: 1870-1913 and Today, Oxford University Press, New York.

Mendoza, E., Quadrini, V., Rios-Rull, J. V. (2007). "Financial integration, financial deepness and global imbalances”. NBER Working Papers 12909. National Bureau of Economic Research, Cambridge, MA.

Miniane, J. (2004). "A new set of measures on capital account restrictions". IMF Staff Papers 51(2), 276-308.

Mishkin, F. S. (2006). The Next Great Globalization: How Disadvantaged Nations Can Harness Their Financial Systems to Get Rich. Princeton University Press, Princeton.

Mishkin, F. S. (2008). “Why We Shouldn’t Turn Our Backs on Financial Globalization”. Forthcoming in IMF Staff Papers.

Mitton, T. (2006). "Stock market liberalization and operating performances at the firm level". Journal of Financial Economics 81(3), 625-647.

Mody, A., Murshid, A. P. (2005). "Growing up with capital flows”. Journal of International Economics 65(1), 249-266.

Moran, T. H. (2005). "How does FDI affect host country development? Using industry case studies to make reliable generalizations". In: Moran, T. H., Graham, E. M., Blomström, M. (Eds.), Does Foreign Investment Promote Development?, Institute for International Economics, Washington.

Neut, A., Velasco, A. (2003). “Touch policies, incredible policies”. NBER Working Papers 9932. National Bureau of Economic Research, Cambridge, MA.

Obstfeld, M., Rogoff, K. (1995). "Exchange rate dynamics redux". Journal of Political Economy 103(3), 624-660. . (2001). "The six major puzzles in international macroeconomics: is there a common cause?” In: Bernanke, B. S., Rogoff, K. (Eds.), NBER Macroeconomics Annual 2000. MIT Press, Cambridge, MA.

- (2004). Foundations of International Macroeconomics. MIT Press, Cambridge, MA.

Obstfeld, M., Taylar, A. M. (2004). Global Capital Markets: Integration, Crisis, and Growth. Cambridge University Press, Cambridge, UK.

Obstfeld, M. (2007). "International finance and growth in developing countries: what have we learned?" Working Paper, University of California, Berkeley. Forthcoming in IMF Staff Papers.

Pallage, S., Robe, M. A. (2003). "On the welfare cost of economic fluctuations in developing countries”. International Economic Review 44(2), 677-698. 
Prasad, E. S. (2008). "Some new perspectives on India's approach to capital account liberalization". Forthcoming in Brookings India Policy Forum.

Prasad, E. S., Rajan, R. (2008). “A pragmatic approach to capital account liberalization”. Journal of Economic Perspectives 22(3), 149-172.

—, Subramanian, A. (2007). "Foreign capital and economic growth". Brookings Papers on Economic Activity 2007(1), 153-230.

Prasad, E. S., Rogoff, K., Wei, S. J., Kose, M. A. (2003). "Effects of Financial Globalization on Developing Countries: Some Empirical Evidence”. IMF Occasional Paper 220. International Monetary Fund, Washington.

Prasad, E. S., Rumbaugh, T., Wang, Q. (2005). "Putting the cart before the horse? Capital account liberalization and exchange rate flexibility in China". IMF Policy Discussion Paper 05/1. International Monetary Fund, Washington.

Prasad, E. S., Wei, S. J. (2007). "The Chinese approach to capital inflows: patterns and possible explanations". In: Edwards, S. (Ed.), Capital Controls and Capital Flows in Emerging Economies: Policies, Practices, and Consequences, National Bureau of Economic Research Conference Report. University of Chicago Press, Chicago.

Quinn, D. (1997). “The correlates of changes in international financial regulation". American Political Science Review 91, 531-551.

. (2003). "Capital account liberalization and financial globalization, 1890-1999: a synoptic view". International Journal of Finance and Economics 8(3), 189-204.

, Toyoda, A. M. (2006). “Does capital account liberalization lead to growth?” Working Paper, Georgetown University.

Rajan, R., Zingales, L. (1998). "Financial dependence and growth". American Economic Review 88(3), 559-586.

Ramey, G., Ramey, V. A. (1995). "Cross-country evidence on the link between volatility and growth". American Economic Review 85(5), 1138-1151.

Razin, A., Rose, A. K. (1994). "Business-cycle volatility and openness: an exploratory crosssectional analysis". In: Leiderman, L., Razin, A. (Eds.), Capital Mobility: The Impact on Consumption, Investment, and Growth, 48-76. Cambridge University Press, Cambridge, UK.

Reinhart, C. M., Reinhart, V. (1998). "Some lessons for policymakers who deal with the mixed blessing of capital inflows". In: Kahler, M. (Ed.), Capital Flows and Financial Crises, 93127. Cornell University Press, Ithaca, NY.

Reinhart, C. M., Rogoff, K. (2004). "The modern history of exchange rate arrangements: a reinterpretation". The Quarterly Journal of Economics 119(1), 1-48.

—, Savastano, M. A. (2003). "Debt intolerance". Brookings Papers on Economic Activity 1:2003, 1-74.

Rodrik, D. (1998). "Who needs capital-account convertibility?”. In: Should the IMF Pursue Capital-Account Convertibility?, Princeton Essays in International Finance 207, 55-65, Princeton University Press, Princeton. 
(1999). The New Global Economy and Developing Countries: Making Openness Work. Overseas Development Council, Washington.

—. (2004). "Industrial policy for the twenty-first century". Working Paper, Harvard University.

- (2007a). "How to save globalization from its cheerleaders". Working Paper, Harvard University.

- (2007b). "The real exchange rate and economic growth: theory and evidence". Working Paper, Harvard University.

—- Subramanian, A. (2008). "Why did financial globalization disappoint?" Manuscript, Harvard University. Forthcoming in IMF Staff Papers.

Rodrik, D., Velasco, A. (2000). "Short-term capital flows”. In: Plescovic, B., Stiglitz, J. E. (Eds.), Annual World Bank Conference on Development Economics 1999, 59-70. World Bank, Washington.

Rogoff, K. (2007). "Impact of globalization on monetary policy”. Federal Reserve Bank of Kansas City Proceedings, 265-305.

Schmukler, S. L. (2004). "Financial globalization: gain and pain for developing countries". Federal Reserve Bank of Atlanta Economic Review (Q2), 39-66.

Schindler, M. (2008). "Measuring Financial Integration: A New Dataset". Forthcoming in IMF Staff Papers.

Spiegel, M. M. (2008). "Financial Globalization and Monetary Policy Discipline: A Survey with New Evidence from Financial Remoteness”. Forthcoming in IMF Staff Papers.

Stiglitz, J. (2002). Globalization and Its Discontents. W. W. Norton and Company, New York. . (2004). "Capital-market liberalization, globalization, and the IMF”. Oxford Review of Economic Policy 20(1), 57-71.

Stulz, R. (1999a). “International portfolio flows and security markets”. In: Feldstein, M., (Ed.), International Capital Flows, 257-293. University of Chicago Press, Chicago. . (1999b). "Globalization of equity markets and the cost of capital". NBER Working Papers 7021. National Bureau of Economic Research, Cambridge, MA.

—. (2005). “The limits of financial globalization”. Journal of Finance 60(4), 1595-1637.

Summers, L. H. (2000). "International financial crises: causes, prevention, and cures". American Economic Review 90(2), 1-16.

Tytell, I., Wei, S. J. (2004). "Does financial globalization induce better macroeconomic policies?” IMF Working Paper 04/84. International Monetary Fund, Washington.

Van Wincoop, E. (1999). "How big are potential welfare gains from international risk sharing?" Journal of International Economics 47(1), 109-135.

Wei, S. J. (2001). "Domestic crony capitalism and international fickle capital: is there a connection?" International Finance 4(1), 15-46. 
— Wu, Y. (2002). "Negative alchemy? Corruption, composition of capital flows, and currency crises". In: Edwards, E. Frankel, J. (Eds.), Preventing Currency Crises in Emerging Markets, 461-501. University of Chicago Press, Chicago.

Wei, S. J., Zhang, Z. (2006). "Collateral damage: exchange controls and international trade". IMF Working Paper 07/08. International Monetary Fund, Washington.

Woodford, M. (2007). “Globalization and monetary control”. NBER Working Papers 13329. National Bureau of Economic Research, Cambridge, MA.

Wurgler, J. (2000). "Financial markets and the allocation of capital". Journal of Financial Economics 58(1-2), 187-214.

Wyplosz, C. (2004). "Financial instability in emerging market countries: causes and remedies". Paper presented at the Forum on Debt and Development (FONDAD) Conference "Stability, growth and the search for a new development agenda: reconsidering the Washington Consensus," Santiago, Chile.

Zettelmeyer, J. (2006). "Growth and reforms in Latin America: a survey of facts and arguments". IMF Working Paper 06/210. International Monetary Fund, Washington. 


\section{Figure II.1. Gross International Financial Assets and Liabilities (trillions of U.S. dollars)}

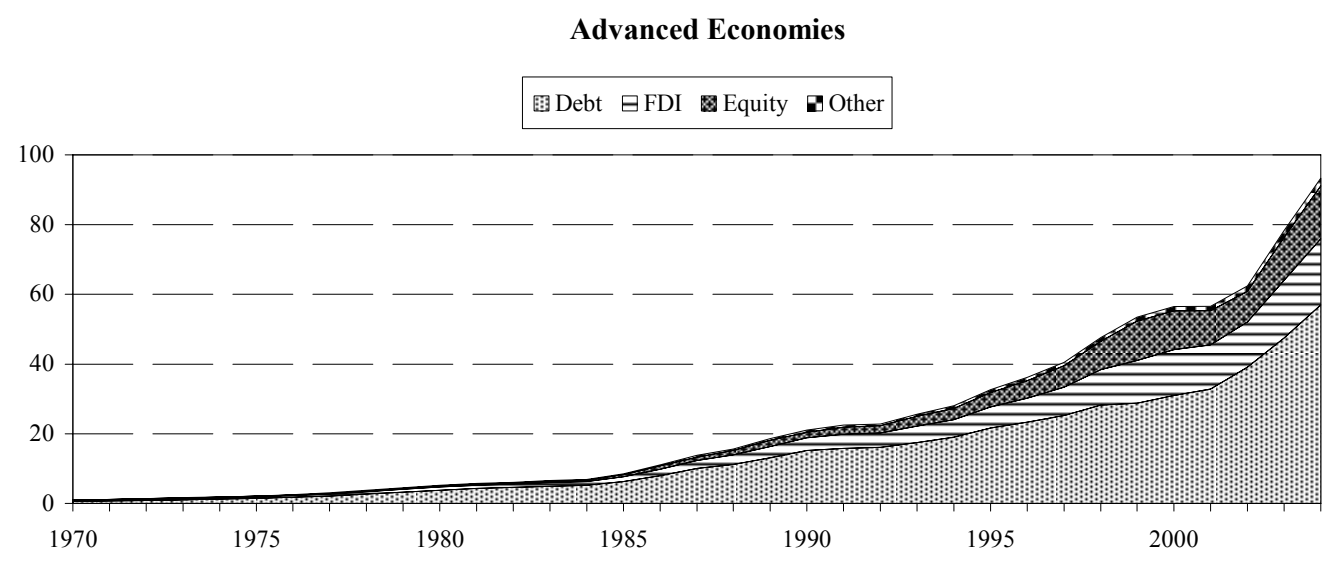

Emerging Markets

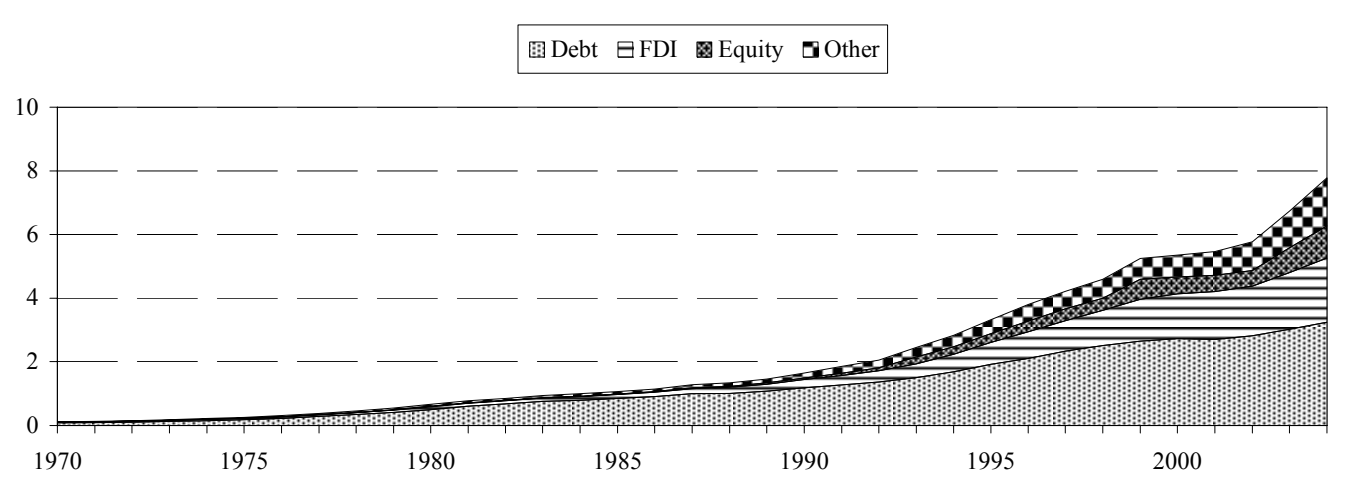

Other Developing Economies

国 Debt $\boxminus$ FDI 圈 Equity 0 Other

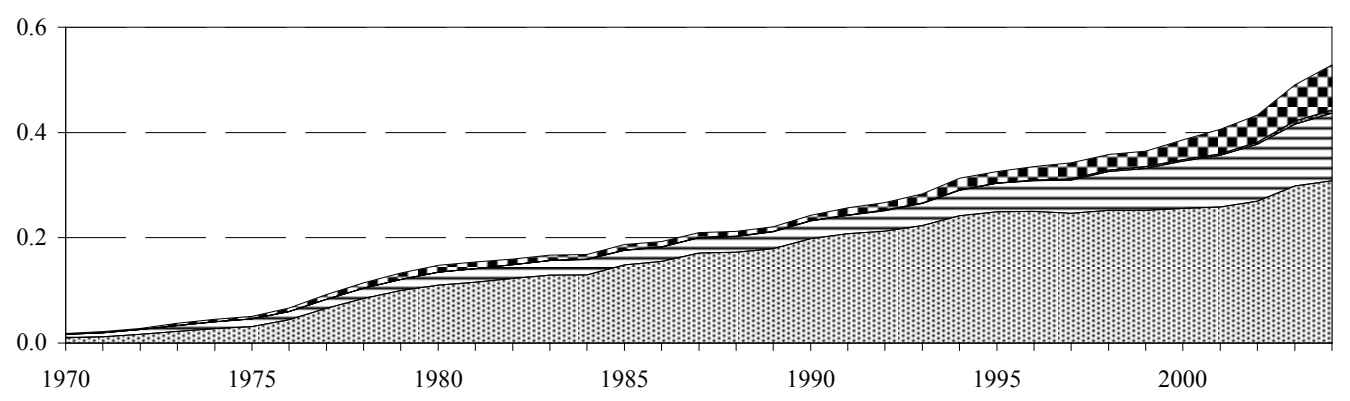

Notes: The financial integration data are based on a dataset constructed by Lane and Milesi-Ferretti (2006). The time period of analysis is 1970-2004. The charts show how the components add up to the total integration measure in each period. Debt includes both official and unofficial debt. The category "Other" includes financial derivatives and total reserves minus gold. 


\section{Figure II.2. Evolution of International Financial Integration}
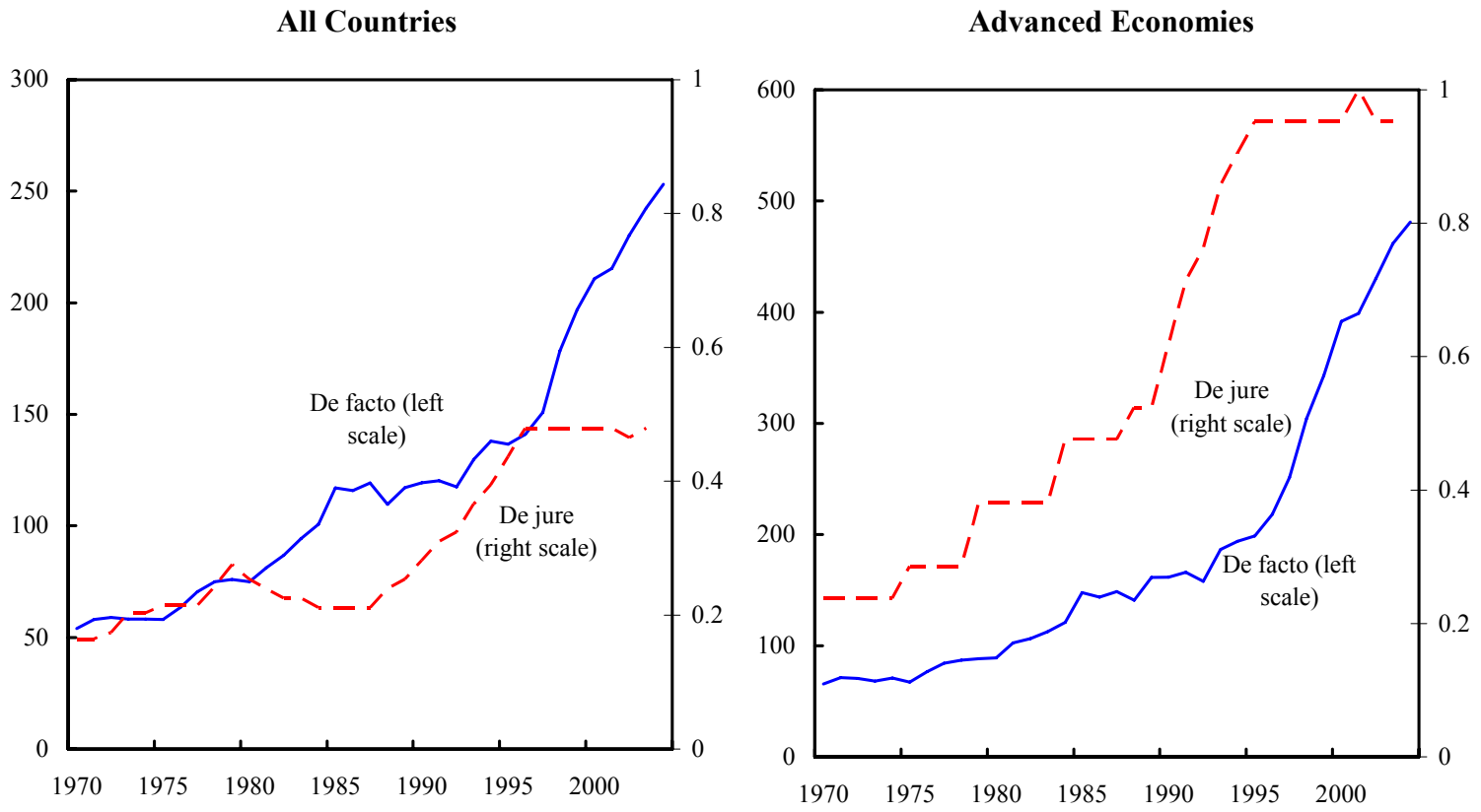

Emerging Markets

Other Developing Economies
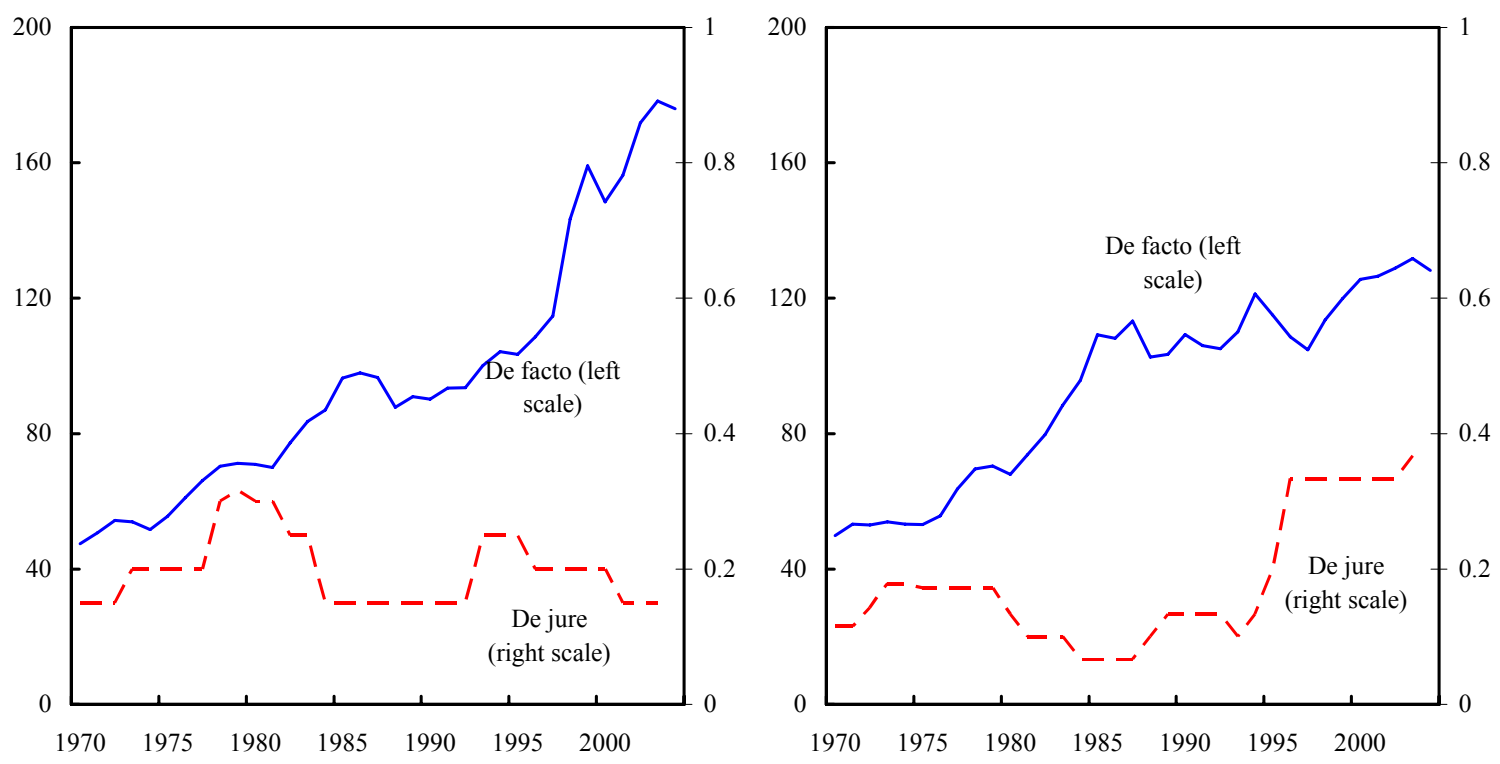

Notes: This figure shows unweighted cross-country averages, within each group, of two measures of capital account openness. The time period of analysis is 1970-2004. The de jure measure is based on the IMF 0-1 capital account restrictiveness classification, with 1 representing countries that have open capital accounts. The de facto measure is based on the ratio of gross stocks of foreign assets and liabilities to GDP (in percent), with the raw data taken from Lane and Milesi-Ferretti (2006). 
Figure II.3. Composition of Gross Stocks of Foreign Assets and Liabilities (in percent)
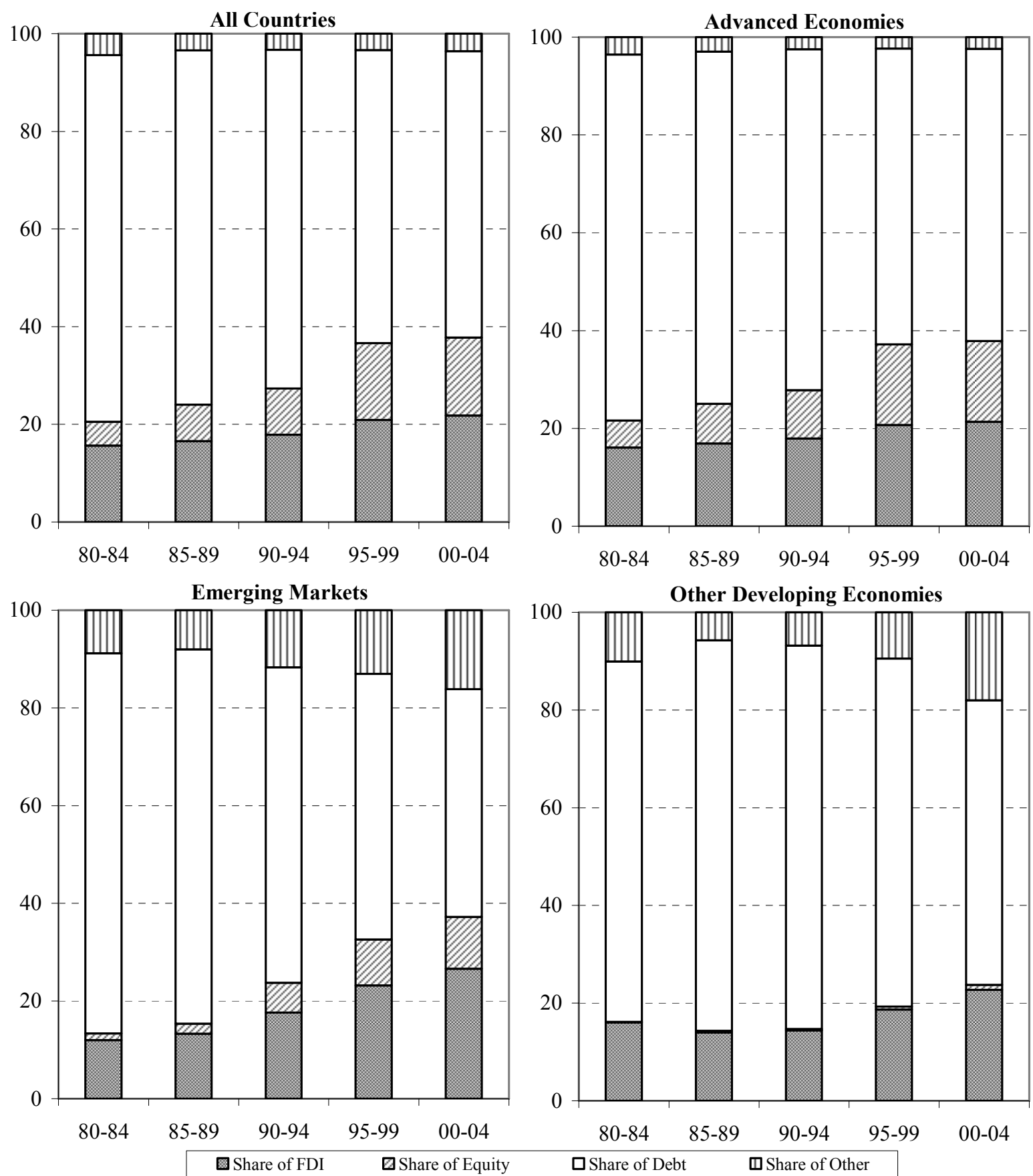

Notes: Data shown in this figure are based on cross-country averages of annual data over the relevant five-year period for each group of countries. The sample comprises 21 industrial, 20 emerging market and 30 other developing countries. The category "Other" includes financial derivatives and total reserves minus gold. Shares are in percentage of total. The raw data are based on a dataset constructed by Lane and Milesi-Ferretti (2006). 


\section{Figure II.4. Evolution of Trade and Financial Liberalization (percentage of open countries)}

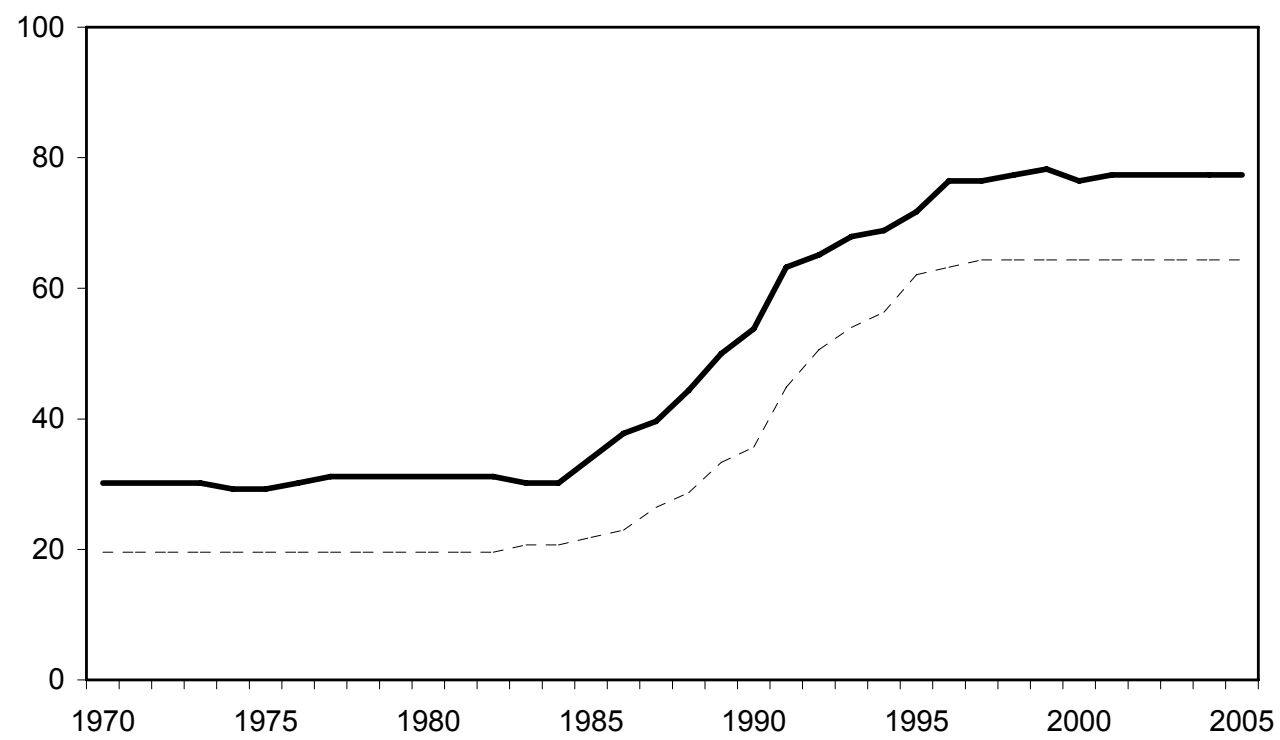

Solid line $=$ Trade Liberalization; Dashed line $=$ Financial Liberalization

Notes: Trade liberalization measure indicates the fraction of countries with a fully liberalized trade regime. The dates of trade liberalization are determined on the basis of the Sachs and Warner (1995) and Wacziarg and Welch (2003). Financial liberalization measure indicates the fraction of countries with a liberalized financial system. The dates of official liberalization are determined on the basis of stock market liberalization and removal of restrictions on foreign investment based on the Bekaert, Harvey, and Lundblad (2005).

Figure II.5. Trade Openness

(Exports+Imports/GDP, in percent)

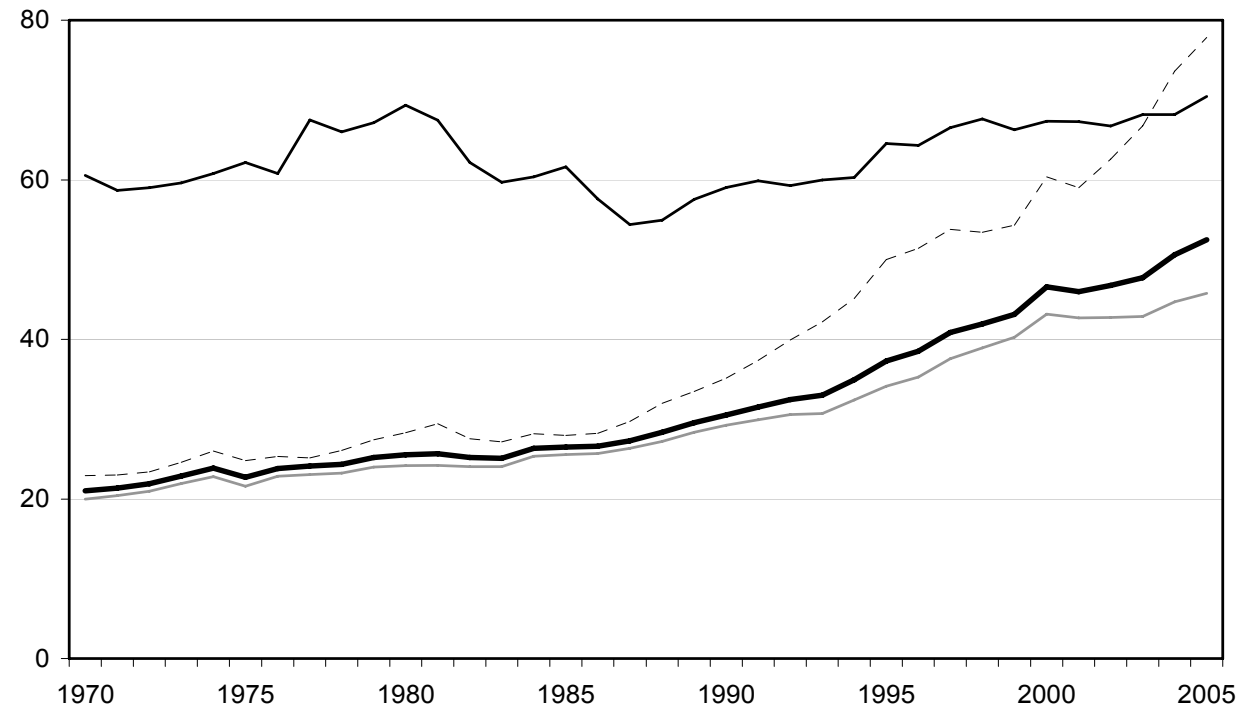

Thick line $=$ World; Gray line: Advanced; Dashed line $=$ Emerging Markets; Thin Line $=$ Other Developing 


\section{Figure III.1. Evolution of GDP (per capita, PPP weighted)}

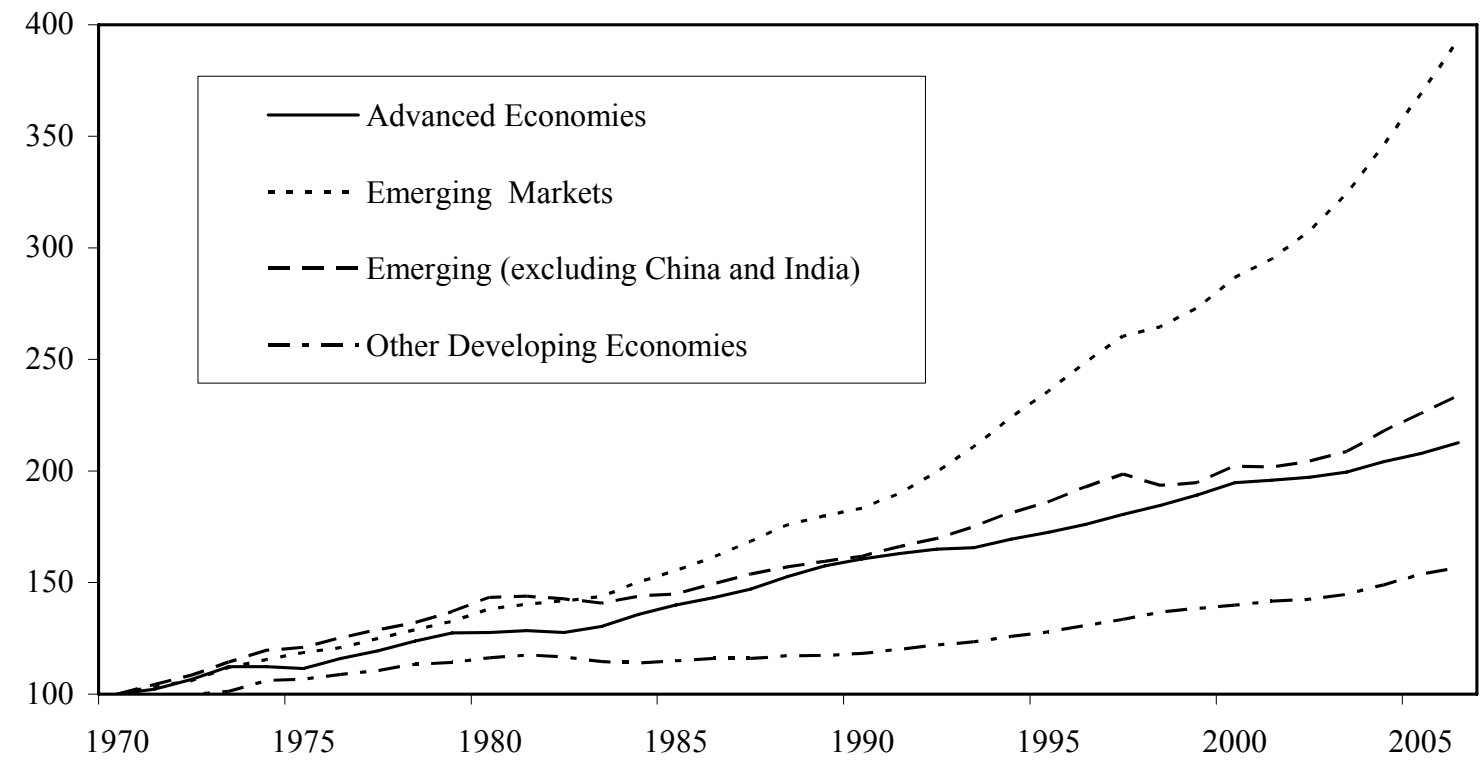

Notes: This plot shows cumulative changes in indexes of per capita GDP for each group of countries, computed using growth rates of real GDP for each country and weighting these by a PPP adjustment factor. The indices are set to 100 in the base period. The time period of analysis is 1970-2006. 
Figure III.2A. Level of Financial Openness and GDP Growth
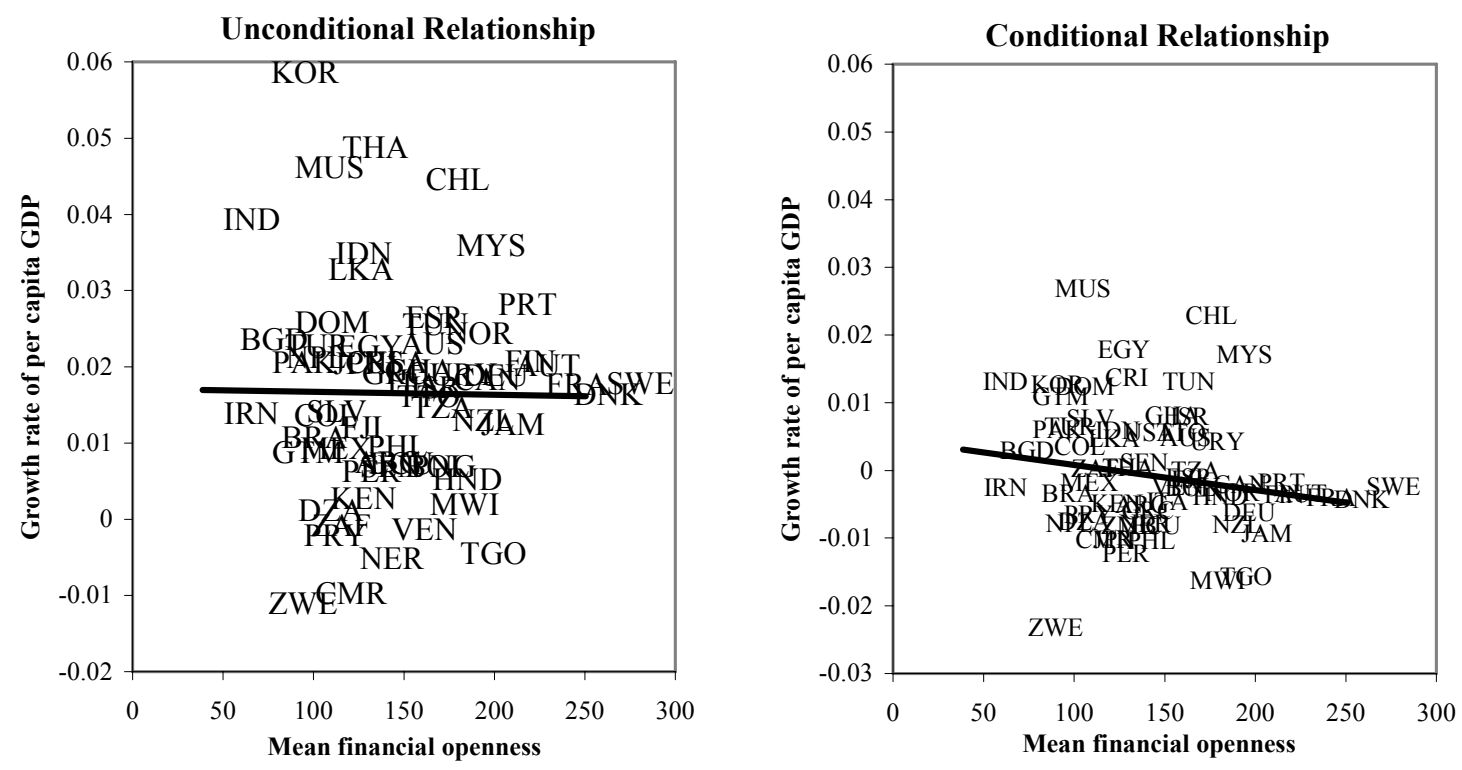

Figure III.2B. Change in Financial Openness and GDP Growth
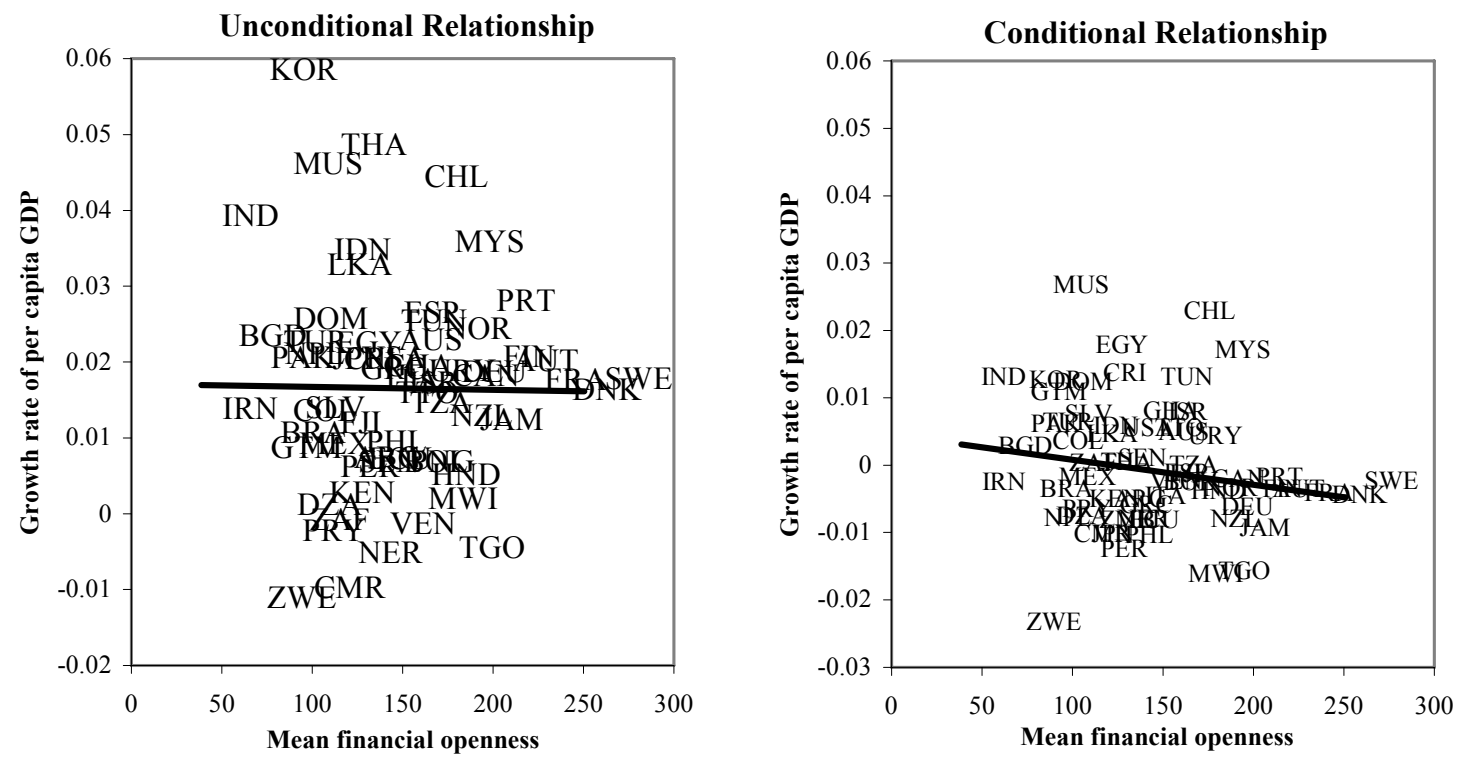

Notes: Growth refers to the average real per capita GDP growth. The time period of analysis is 1985-2004. Financial openness is defined as the ratio of gross stocks of foreign assets and liabilities to GDP and is based on a dataset constructed by Lane and Milesi-Ferretti (2006). The second panel uses residuals from a cross-section regression of growth on initial income, population growth, human capital and the investment rate. 


\section{Figure III.3. Growth Before and After Equity Market Liberalization (Medians)}

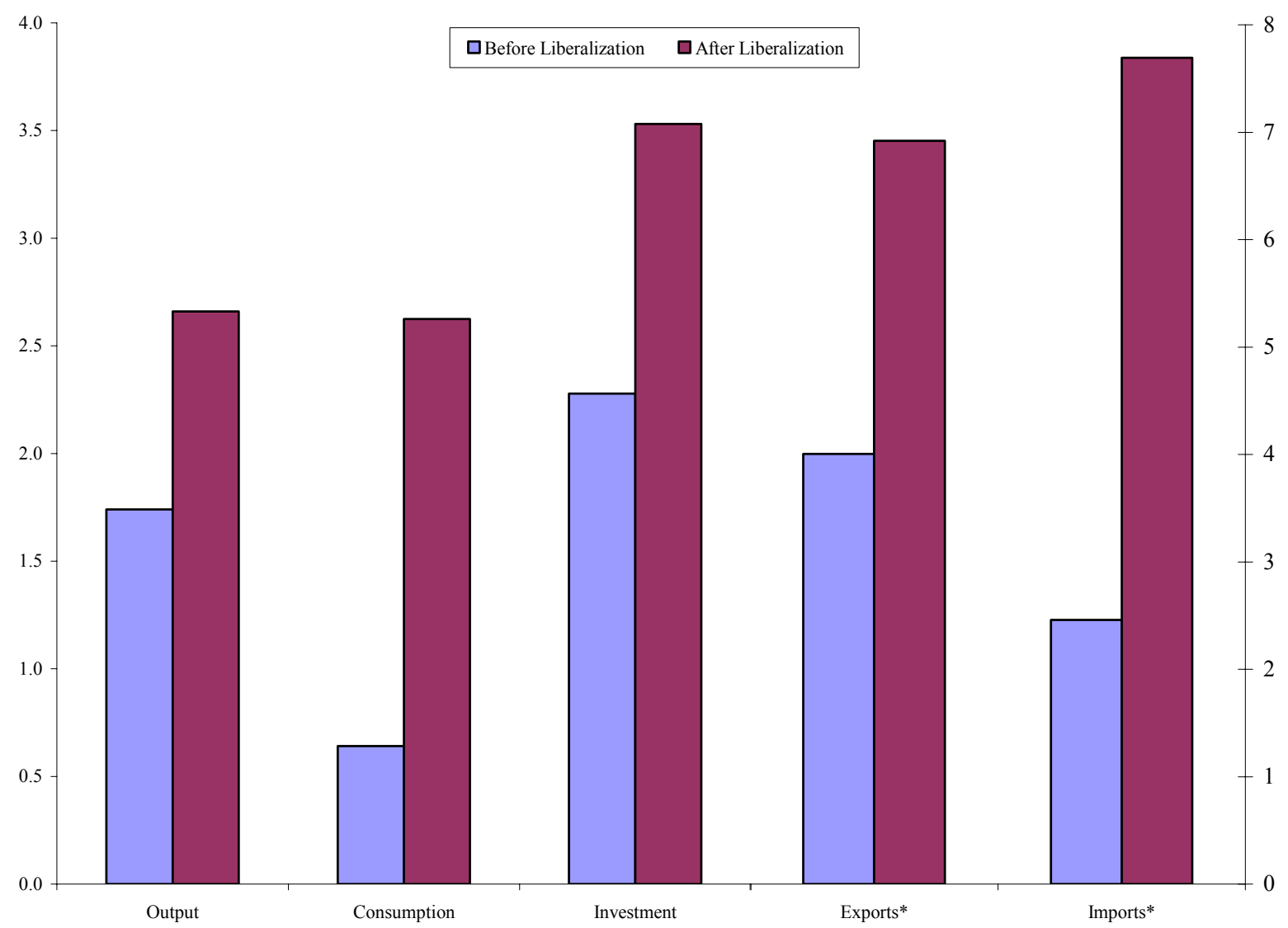

Notes: The time period of analysis is 1980 to 2000 . Countries with less than five observations, either before or after liberalization have been dropped from the sample. * Indicate categories plotted against right axis. The dates of official liberalization are determined on the basis of stock market liberalization and removal of restrictions on foreign investment based on the Bekaert, Harvey, and Lundblad (2005). 


\section{Figure III.4A. Financial Openness and Financial Development}
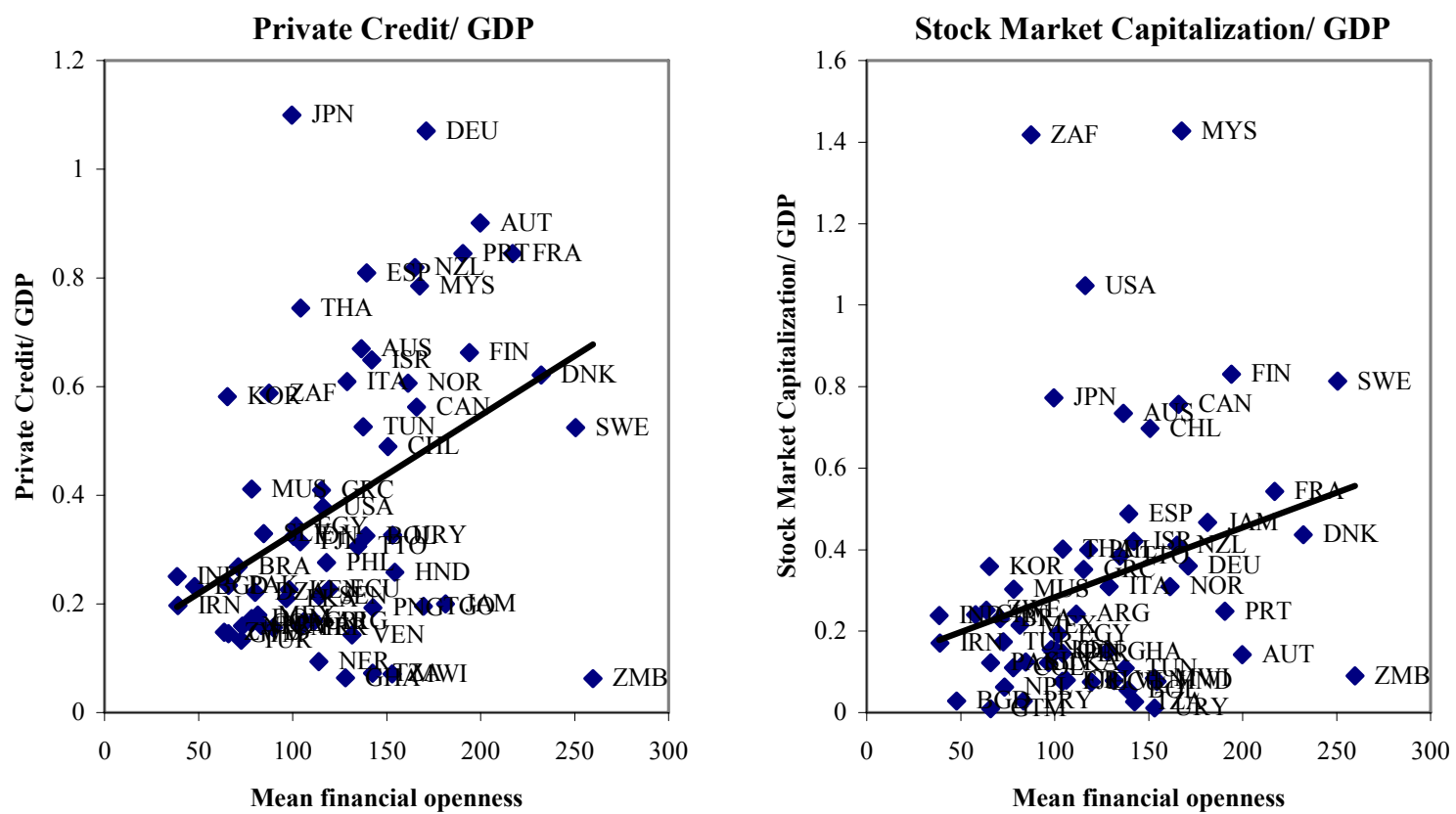

Figure III.4B. Financial Openness and Institutional Quality
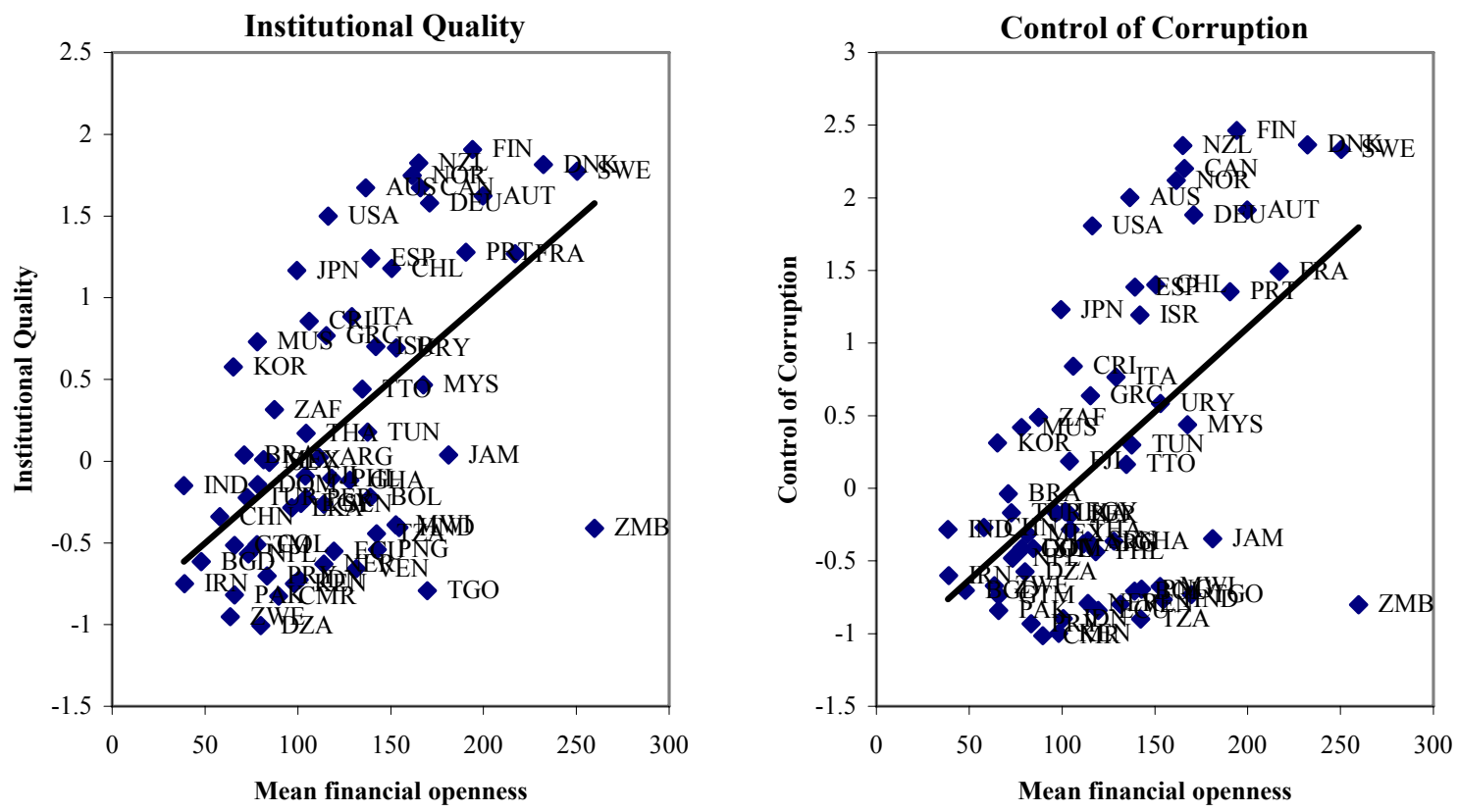


\section{Figure III.4C. Financial Openness and Macroeconomic Policies}
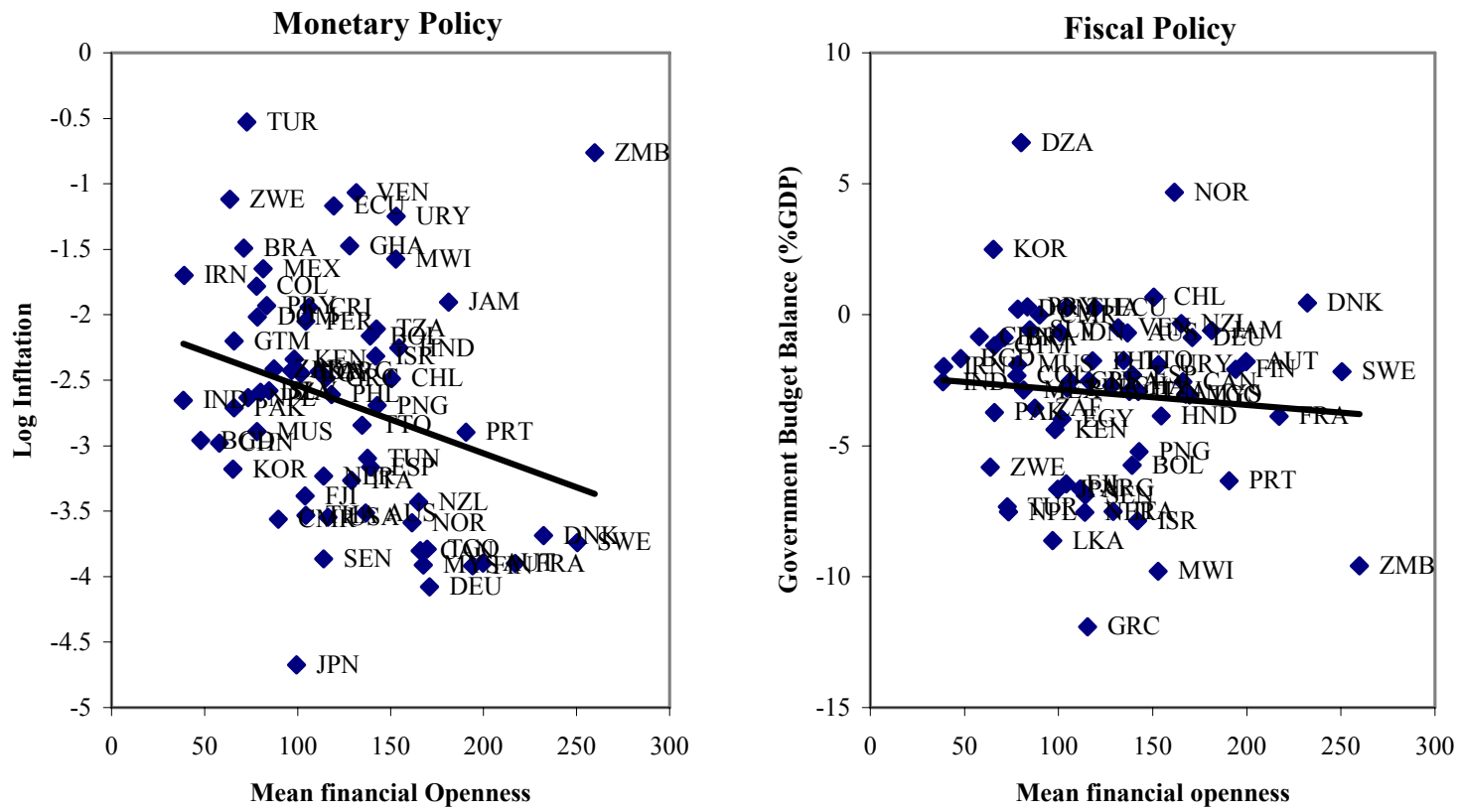

Notes: The financial integration data are based on a dataset constructed by Lane and Milesi-Ferretti (2006). The time period of analysis is 1985-2004. Financial Development data are taken from Beck and Al-Hussainy (2006). Private Credit refers to credit given to the private sector by deposit money banks and Stock Market Capitalization is defined as the value of listed shares. Institutional quality data are from Daniel Kaufmann, Aart Kraay and Massimo Mastruzzi (2005) and cover the period 1996-2004. Institutional Quality is the average of the following indicators: Voice and Accountability, Political Stability, Government Effectiveness, Regulatory Quality, Rule of Law, and Control of Corruption. Monetary and Fiscal data are from WDI, WEO and IFS. Inflation is defined as the annual change in CPI. Government Budget Balance is the difference between Government Revenues and Government Expenditures. 


\section{Figure III.5. Financial Openness and Productivity Growth (Median Values; in percent)}

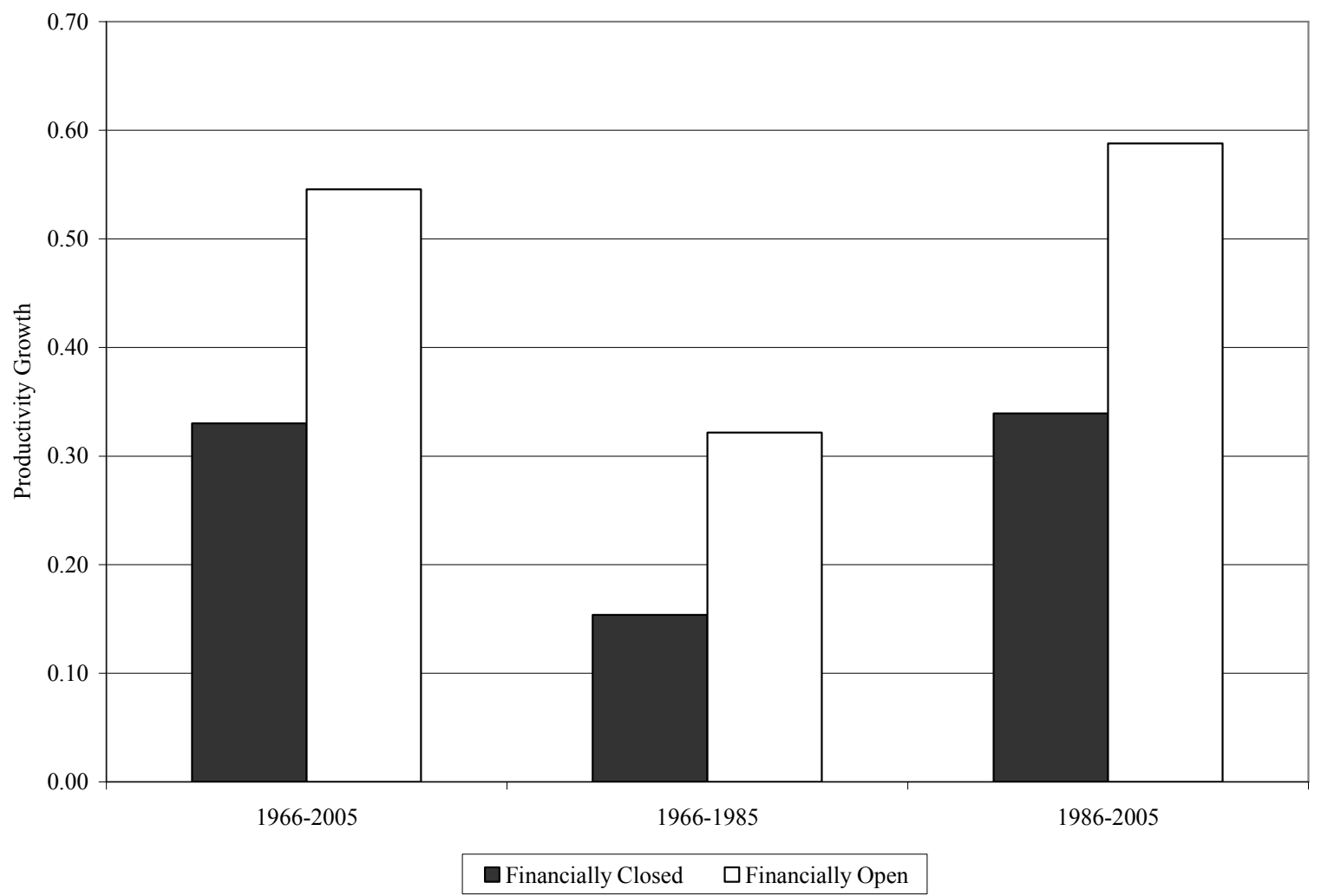

Notes: The measure of total factor productivity is based on a standard growth accounting exercise. Aggregate output is described by the Cobb-Douglas production function with labor, physical and human capital as factors of production. The degree of financial openness is based on the stock of liabilities relative to GDP. Financially open/closed sub-samples are defined relative to the median of the full sample. 


\section{Figure III.6. Evolution of Risk Sharing}
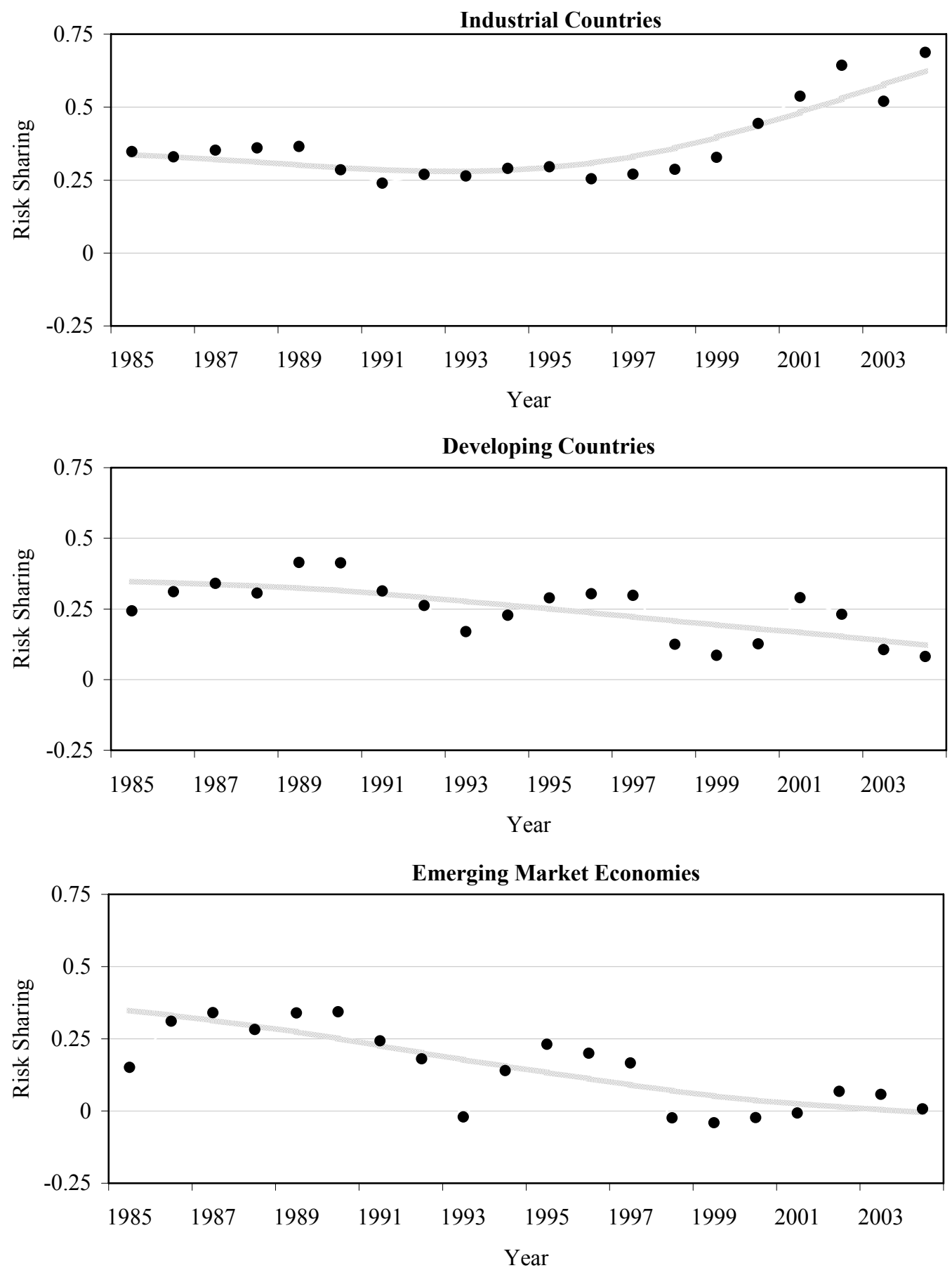

Notes: The degree of risk sharing is based on a regression of a country's idiosyncratic consumption growth on its idiosyncratic output growth (Obstfeld 1995). These regressions are estimated for each country over rolling nine-year periods. World aggregates are calculated using industrial-country data. Medians for each group of countries are reported. The continuous line is the HP filter trend. Emerging Market Economies are part of the group of Developing Countries. 


\section{Table IV.1. Output Growth and Threshold Factors (in percent)}

\begin{tabular}{|c|c|c|c|c|c|}
\hline & & \multicolumn{2}{|c|}{ Unconditional growth } & \multicolumn{2}{|c|}{ Conditional growth } \\
\hline & & $\begin{array}{l}\text { Emerging } \\
\text { Markets }\end{array}$ & $\begin{array}{l}\text { Other } \\
\text { Developing } \\
\text { Countries }\end{array}$ & $\begin{array}{l}\text { Emerging } \\
\text { Markets }\end{array}$ & $\begin{array}{l}\text { Other } \\
\text { Developing } \\
\text { Countries } \\
\end{array}$ \\
\hline Overall & & $2.28(1.94)$ & $0.82(0.65)$ & $0.44(0.53)$ & $-0.16(-0.04)$ \\
\hline \multicolumn{6}{|l|}{ Financial Sector Development } \\
\hline \multirow[t]{3}{*}{ By private credit to GDP } & High & $3.16(3.11)$ & $0.66(0.45)$ & $0.73(0.67)$ & $-0.26(-0.20)$ \\
\hline & Low & $1.49(1.41)$ & $0.98(0.88)$ & $0.18(0.50)$ & $-0.06(0.14)$ \\
\hline & Difference in means & $1.67 *$ & -0.33 & 0.56 & -0.19 \\
\hline \multicolumn{6}{|l|}{ Institutional Quality } \\
\hline \multirow[t]{3}{*}{ By average WBGI institutional quality index } & High & $2.42(1.88)$ & $1.22(0.85)$ & $0.39(0.42)$ & $0.37(0.13)$ \\
\hline & Low & $2.17(1.94)$ & $0.42(0.41)$ & $0.48(0.63)$ & $-0.68(-0.12)$ \\
\hline & Difference in means & 0.25 & $0.80 *$ & -0.09 & $1.06^{* *}$ \\
\hline \multicolumn{6}{|l|}{ Trade Openness } \\
\hline \multirow[t]{3}{*}{ By de facto trade openness } & High & $2.74(2.66)$ & $1.26(0.71)$ & $0.51(0.52)$ & $0.14(0.01)$ \\
\hline & Low & $1.87(1.20)$ & $0.63(0.87)$ & $0.38(0.66)$ & $-0.52(0.02)$ \\
\hline & Difference in means & 0.87 & 0.63 & 0.13 & 0.66 \\
\hline \multicolumn{6}{|l|}{ Macroeconomic Policies } \\
\hline \multirow[t]{3}{*}{ By st. dev of CPI inflation } & Low & $3.38(3.37)$ & $1.51(1.54)$ & $1.07(0.97)$ & $0.40(0.38)$ \\
\hline & High & $1.08(1.15)$ & $0.22(0.35)$ & $-0.26(-0.24)$ & $-0.84(-0.81)$ \\
\hline & Difference in means & $2.30 * * *$ & $1.29 * * *$ & $1.33 * * *$ & $1.24 * * *$ \\
\hline \multirow[t]{3}{*}{ By government expenditure to revenue ratio } & Low & $2.68(2.88)$ & $1.28(1.16)$ & $0.43(0.53)$ & $0.28(0.39)$ \\
\hline & High & $1.54(1.33)$ & $0.53(0.49)$ & $0.16(0.01)$ & $-0.30(-0.12)$ \\
\hline & Difference in means & 1.13 & 0.75 & 0.27 & 0.59 \\
\hline
\end{tabular}




\section{Figure V.1. Corruption and Foreign Direct Investment}

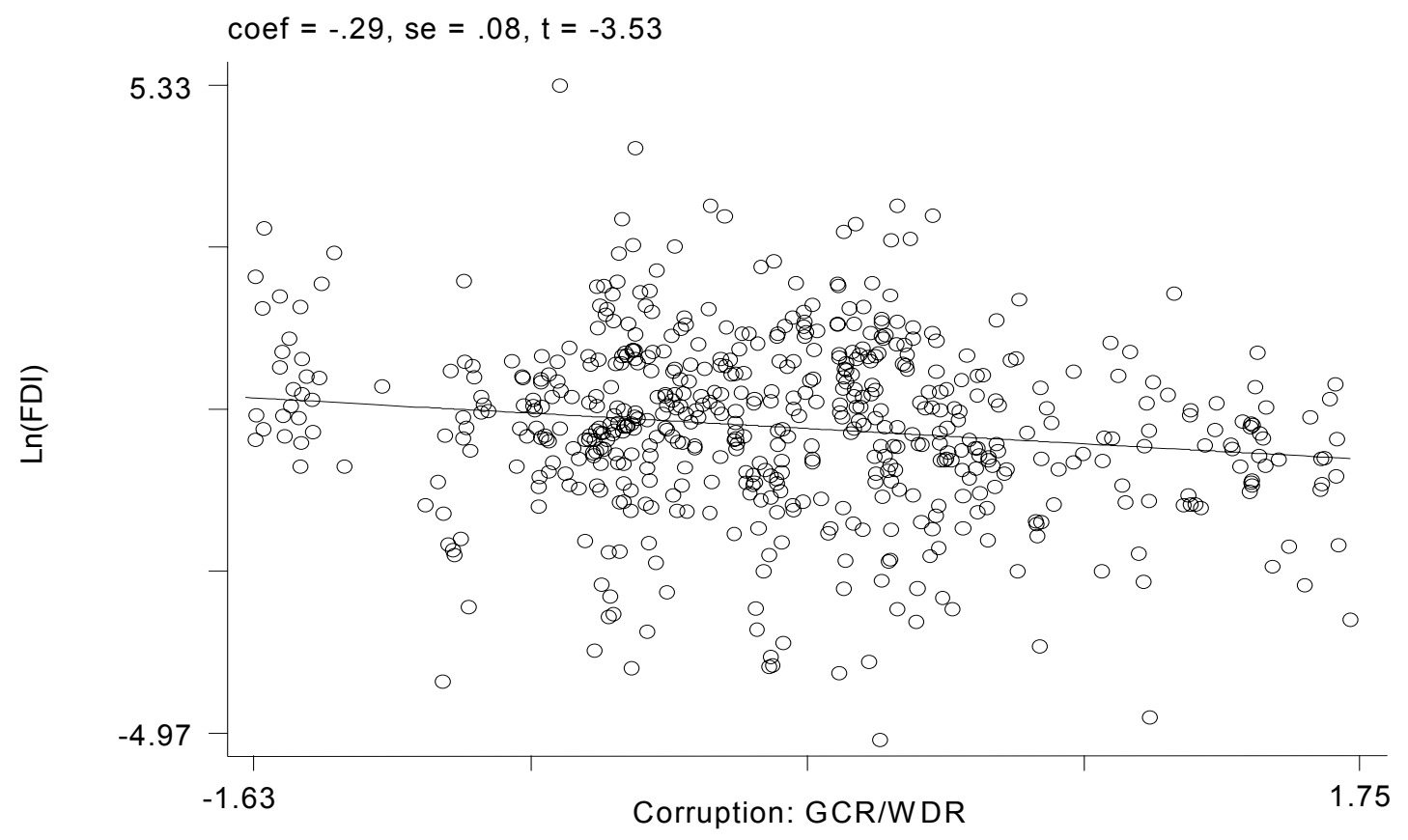

Note: Bilateral foreign direct investment from 14 major source countries to 41 host countries, averaged over 1996-1998. Index of host country corruption is derived by combining the measures from the Global Competitiveness Report (World Economic Forum and Harvard University, 1997) and World Development Report (World Bank 1997). More details can be found in Wei (2001). 
Figure V.2. Corruption and the Composition of Capital Flows

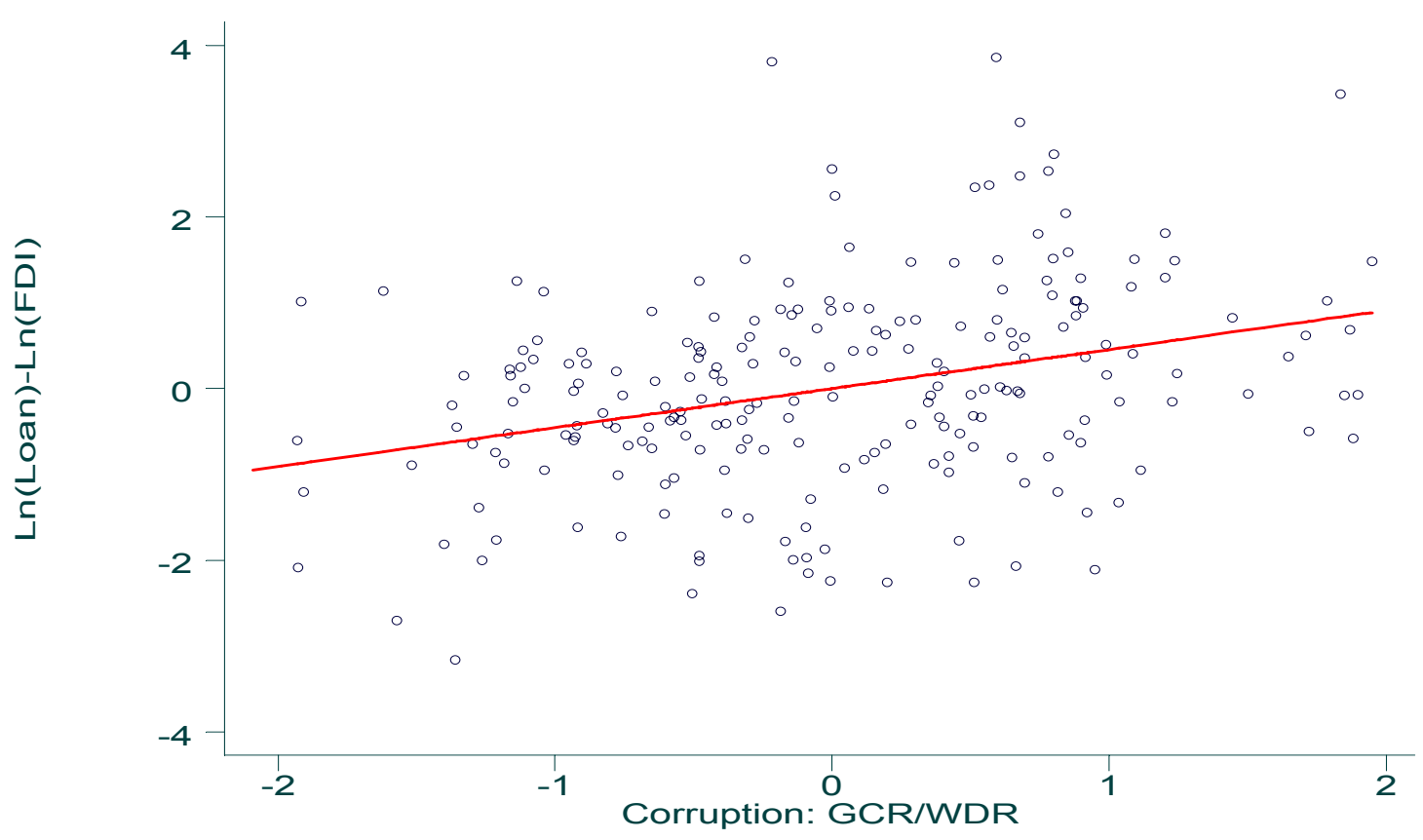

Notes: The index of host country corruption is derived by combining the measures from the Global Competitiveness Report (World Economic Forum and Harvard University, 1997) and World Development Report (World Bank 1997). Controlling for recipient country fixed effects, size, level of development, policy incentives and restrictions on FDI, geographic and linguistic connections. 


\section{Figure V.3. Output Growth and Volatility}

(simple correlations)

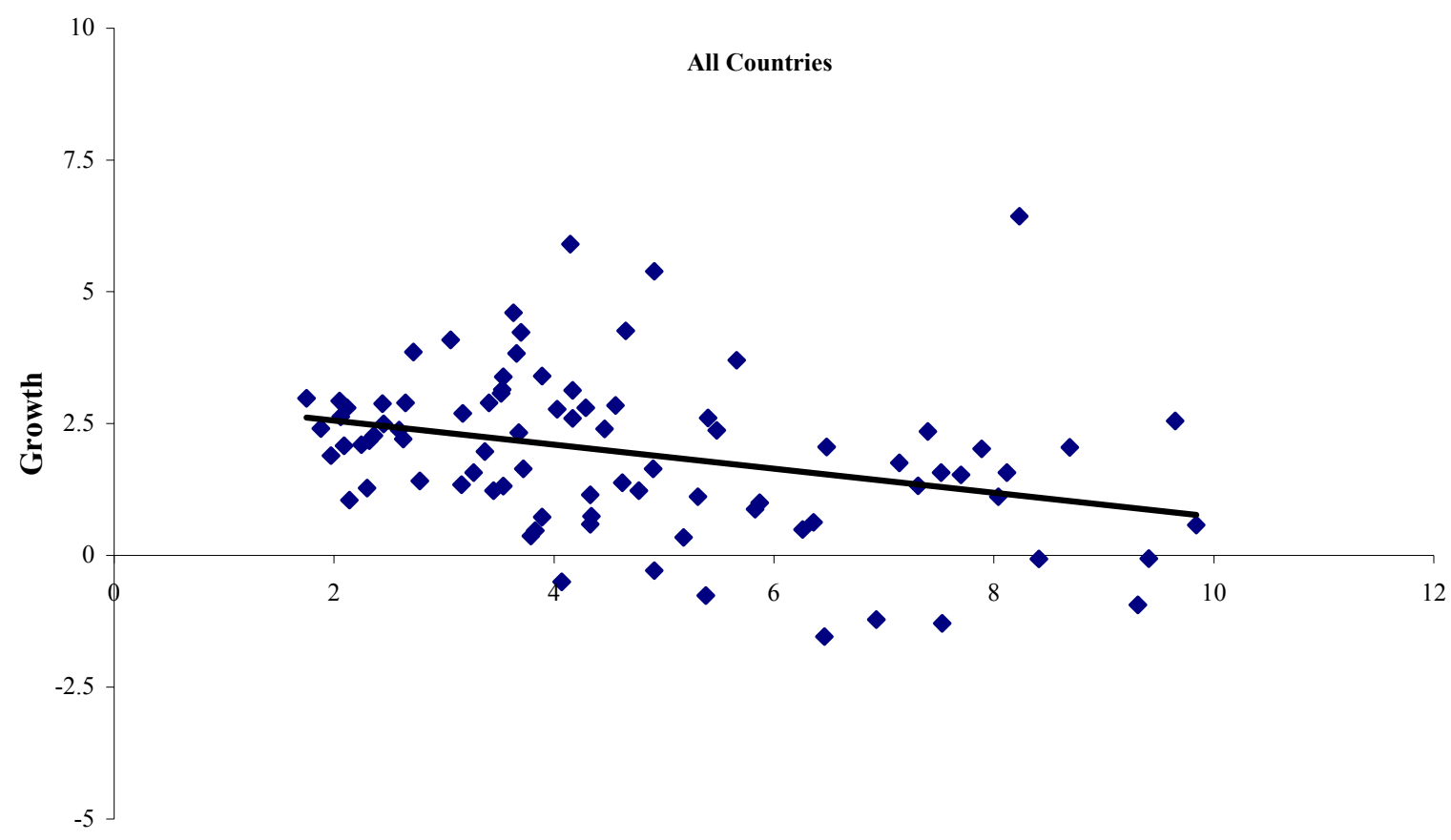

Volatility

Notes: Growth is the average annual growth of real GDP. Volatility is the standard deviation of annual real GDP growth. The time period of analysis is $1960-2000$. 
Figure V.4. Output Growth and Volatility

(simple correlations)
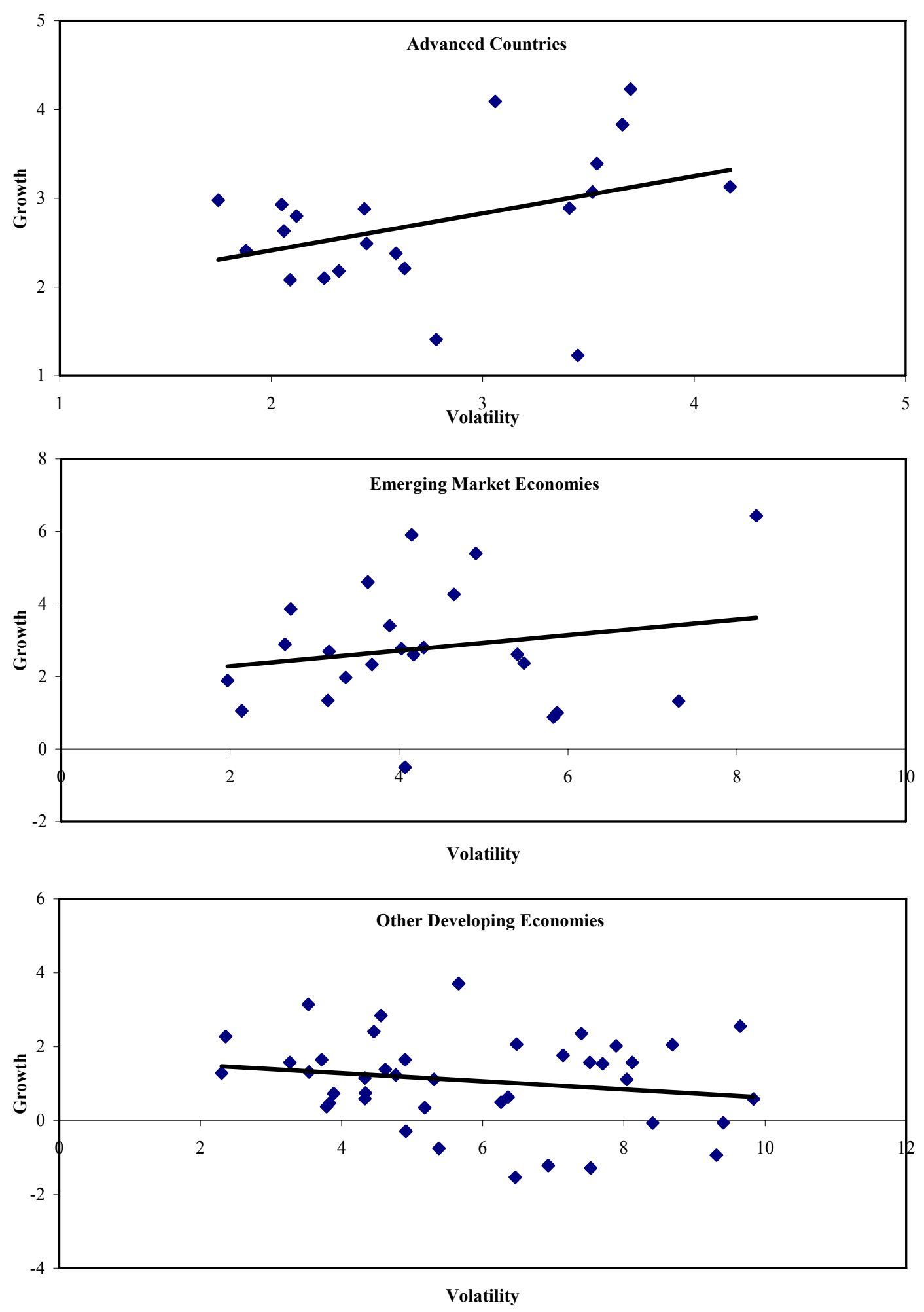

Notes: Growth is the average annual growth of real GDP. Volatility is the standard deviation of annual real GDP growth. 
Figure V.5. Output Growth and Volatility in Emerging Economies (before and after trade and financial liberalization, simple correlations)
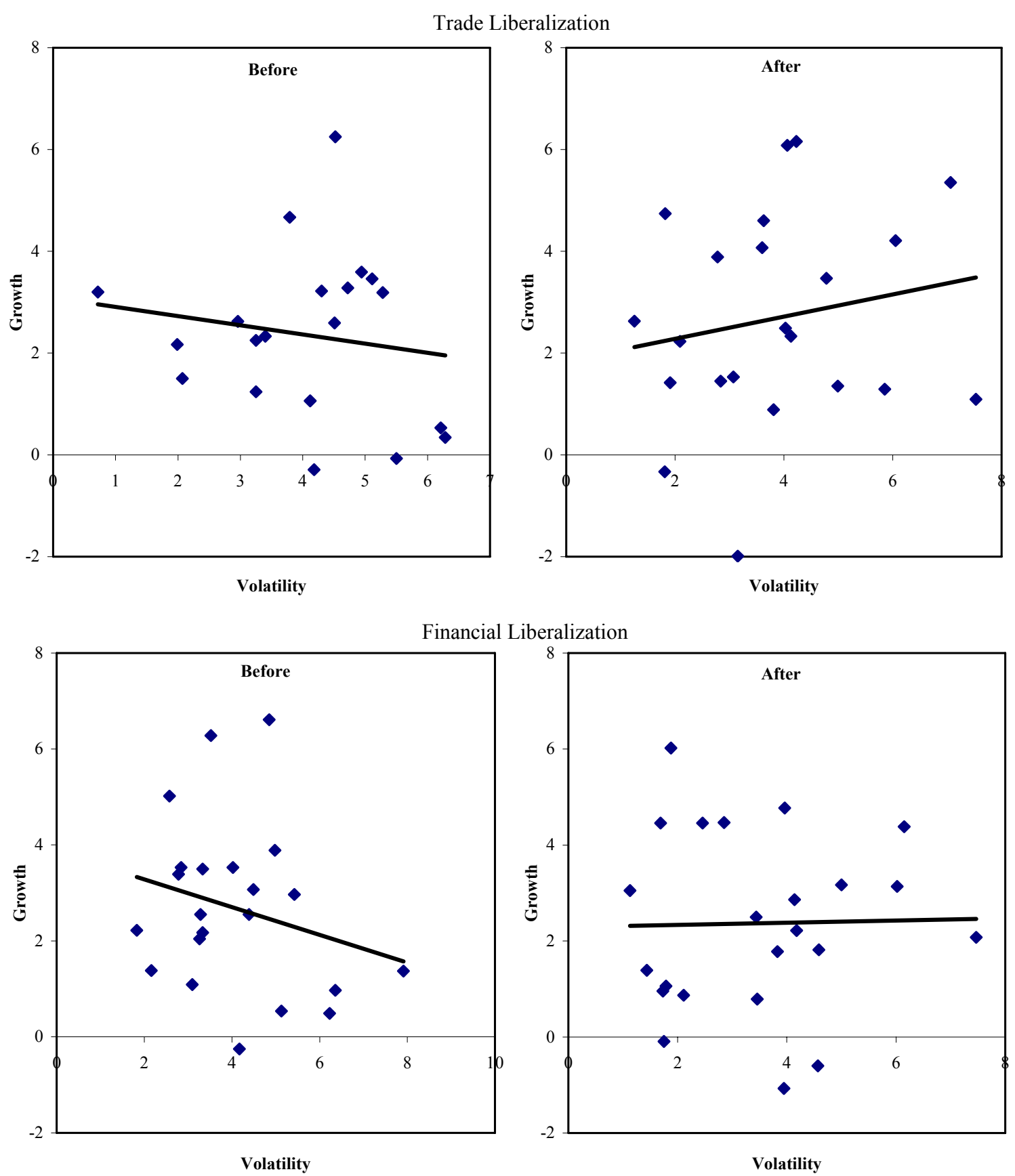

Source: Growth is the average annual growth of real GDP. Volatility is the standard deviation of annual real GDP growth. The dates of official liberalization are determined on the basis of stock market liberalization and removal of restrictions on foreign investment based on the Bekaert, Harvey, and Lundblad (2005). 
Figure VII.1. Relative GDP per Capita of Capital Exporters and Capital Importers (Percent of highest GDP per capita in indicated year)

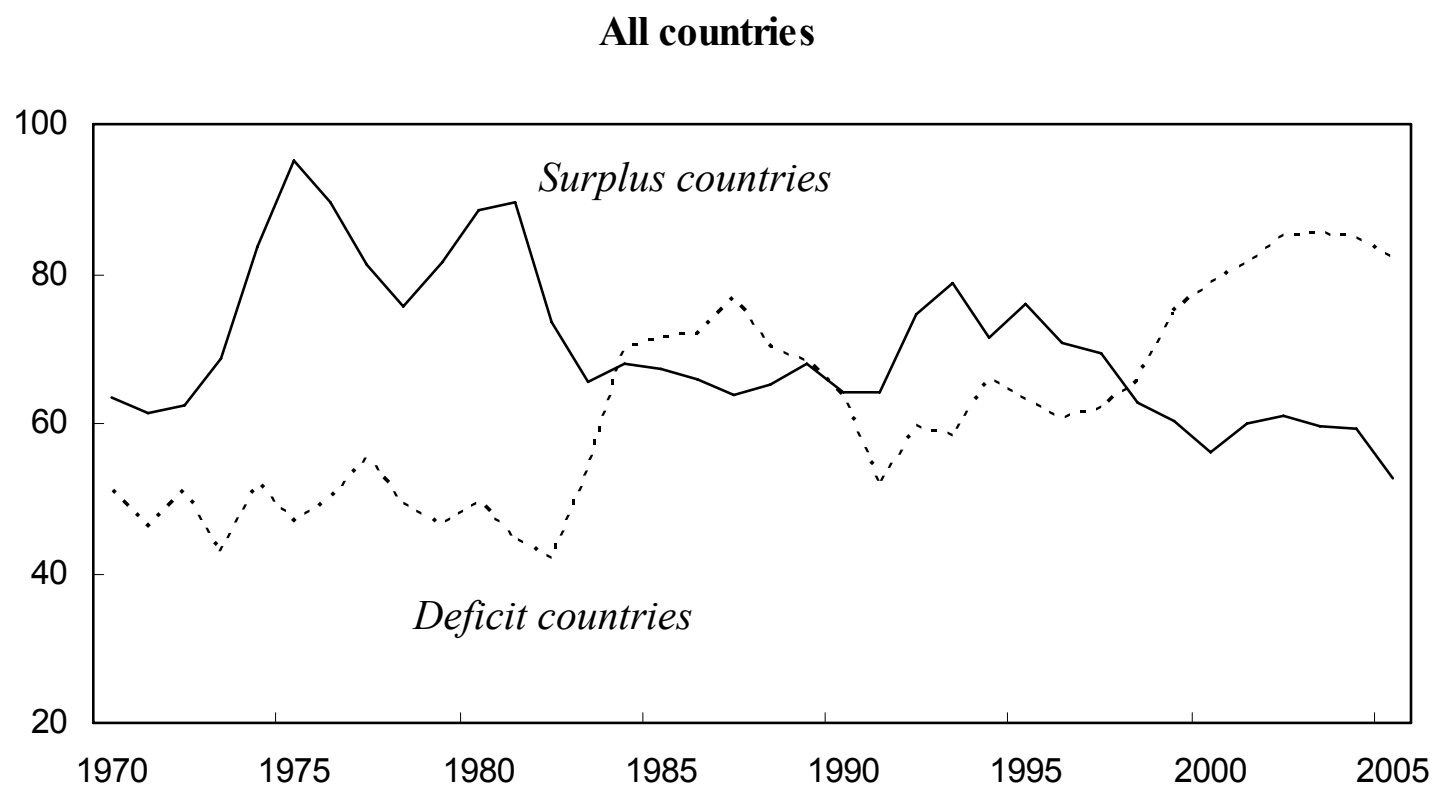

\section{Excluding China and United States}

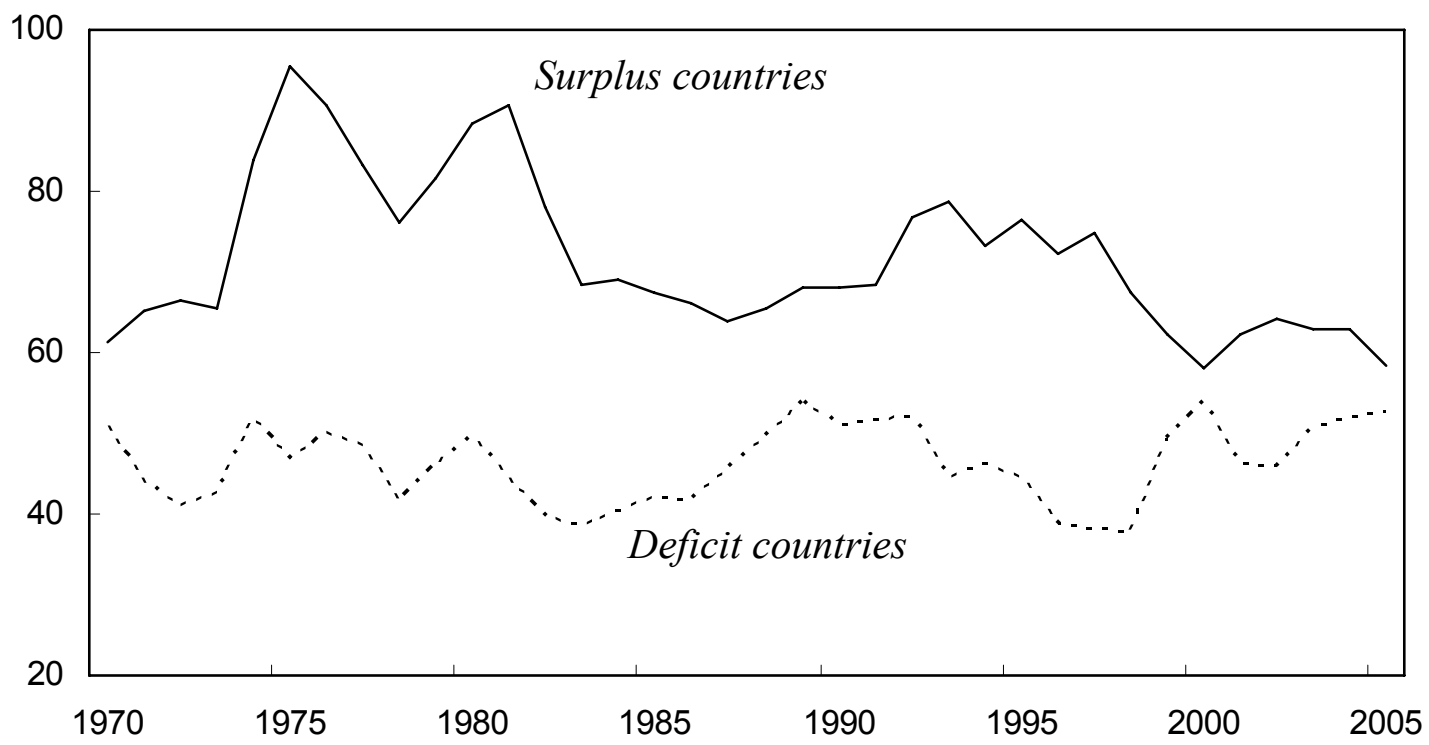

Notes: Each observation is the average GDP per capita (weighted by the country's share of the total current surplus or deficit) of countries in the WEO database with current account surpluses or deficits in the indicated year, expressed as a percentage of GDP per capita in the country with the highest GDP per capita that year. GDP per capita is adjusted for purchasing power parity. Raw data from the WEO database. The period of analysis is 1970- 2005. 
Figure VII.2. Growth in GDP per Capita and Level of Current Account Balances (Growth in GDP per capita; percent a year)

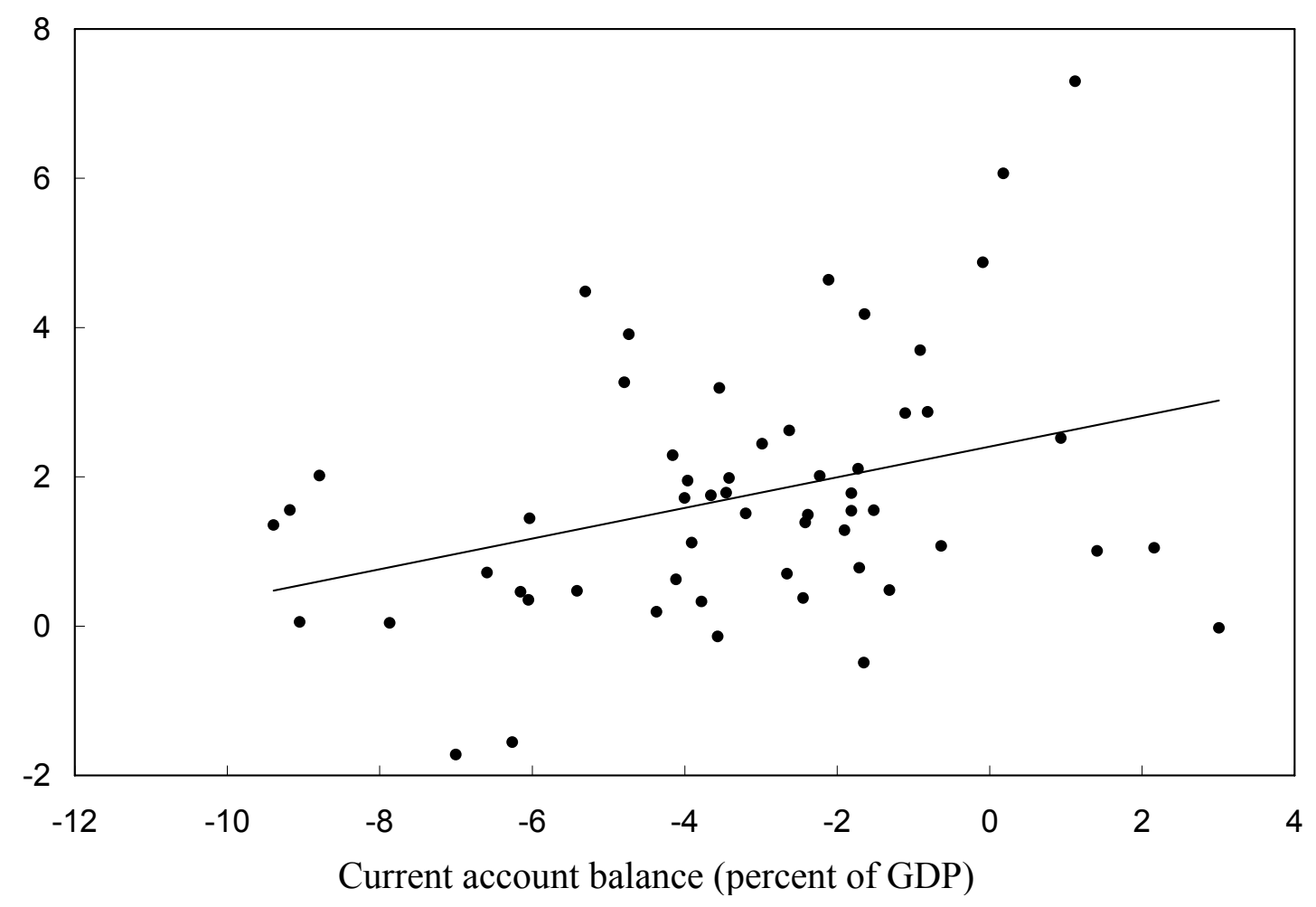

Notes: Data are for the fifty-six non-industrial countries in the core sample. Raw data from the Penn World Tables and the World Bank, World Development Indicators. The period of analysis is 1970-2004. 
Figure VII.3. Growth in GDP per Capita and Levels of Investment and the Current Account

(Growth in GDP per capita; percent a year)

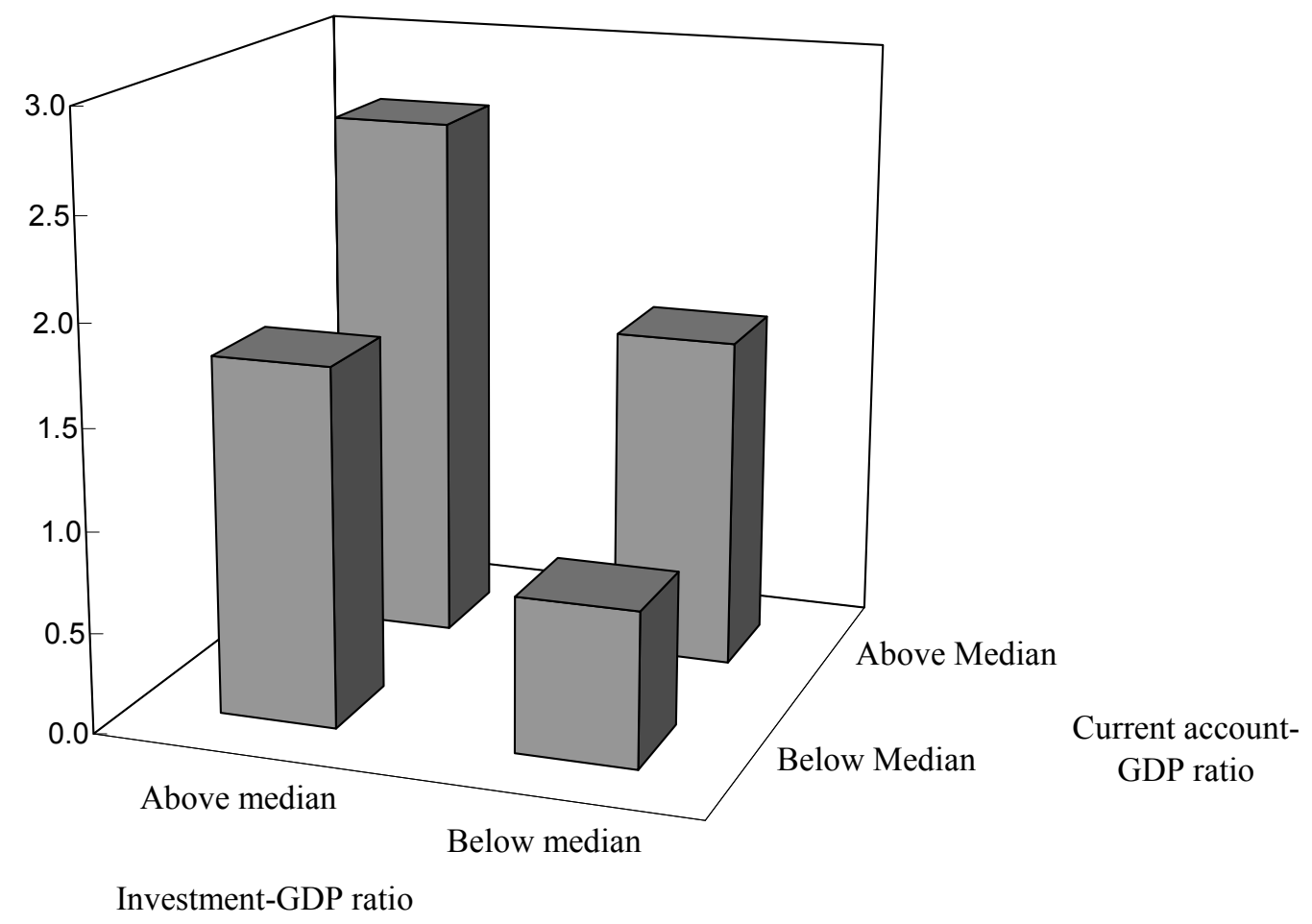

Notes: Data are for the fifty-nine non-industrial countries in the entire sample plus Bangladesh. All data are period averages. Raw data from the World Bank, World Development Indicators. The period of analysis is 1970-2004. 


\section{Figure VIII.1. Controls on Capital Inflows and Selected Macroeconomic Indicators}

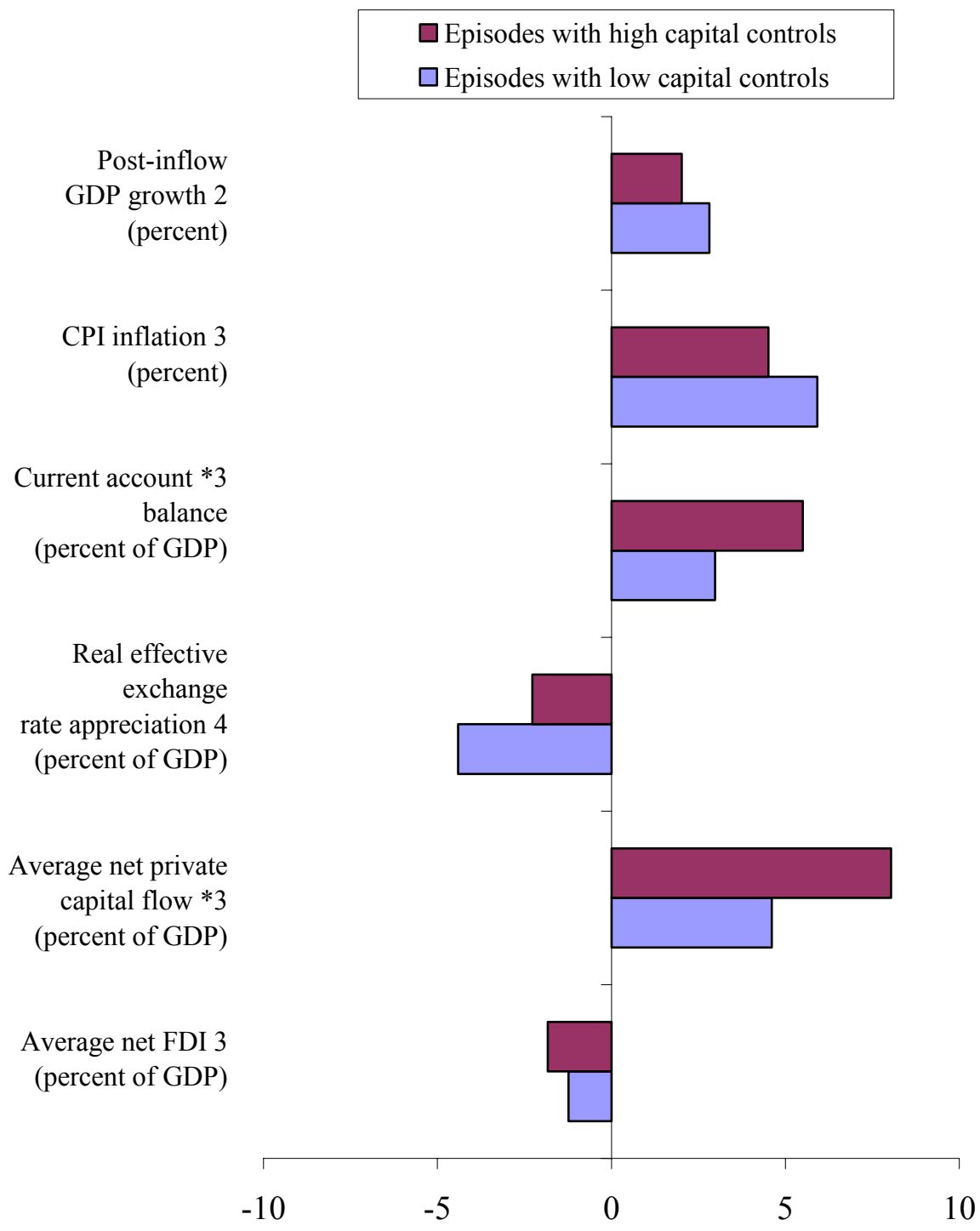

1 Values reported are medians for the two groups of episodes. Episodes with high (low) capital controls are those with above (below) median values of the capital controls index discussed in the text, where higher (lower) values indicate tighter (looser) regulation of inflows. The asterisk $(*)$ indicates that the difference between medians is significant at a 10 percent confidence level or better.

2Average real GDP growth in the two years after an episode minus average during the episode.

3 Average during the episode.

4Cumulative change during the episode.

Data Sources: IMF, Annual Report on Exchange Arrangements and Exchange Restrictions; IMF, Balance of Payments Statistics; and IMF staff calculations. 


\section{Figure VIII.2. Endings of Episodes and Controls on Capital Inflows}

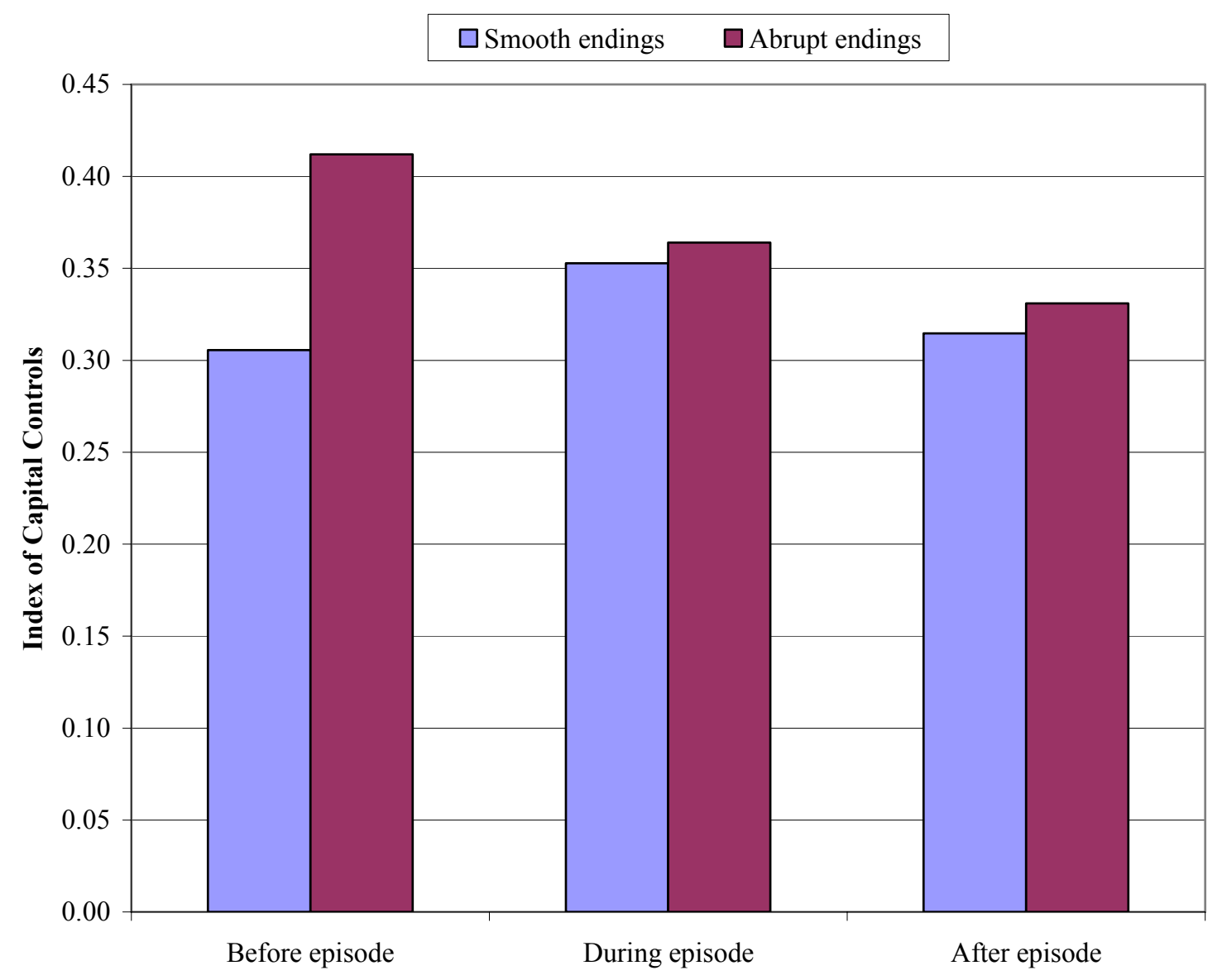

Notes: Median values across all completed episodes using the index of capital controls discussed in the text, where higher values indicate tighter regulation of inflows. "Before" denotes averages of the index in the two years before the episode. "After" denotes averages of the index in the two years after the episode.

An episode is considered to end "abruptly" if the ratio of net private capital inflows to GDP in the year after the episode terminates is more than 5 percentage points of GDP lower than at the end of the episode - closely following the definition of "sudden stops" in the literature. An episode is also considered to finish abruptly if its end coincides with a currency crisis, that is, with a steep depreciation of the exchange rate.

Data Sources: IMF, Annual Report on Exchange Arrangements and Exchange Restrictions; and IMF staff calculations. 


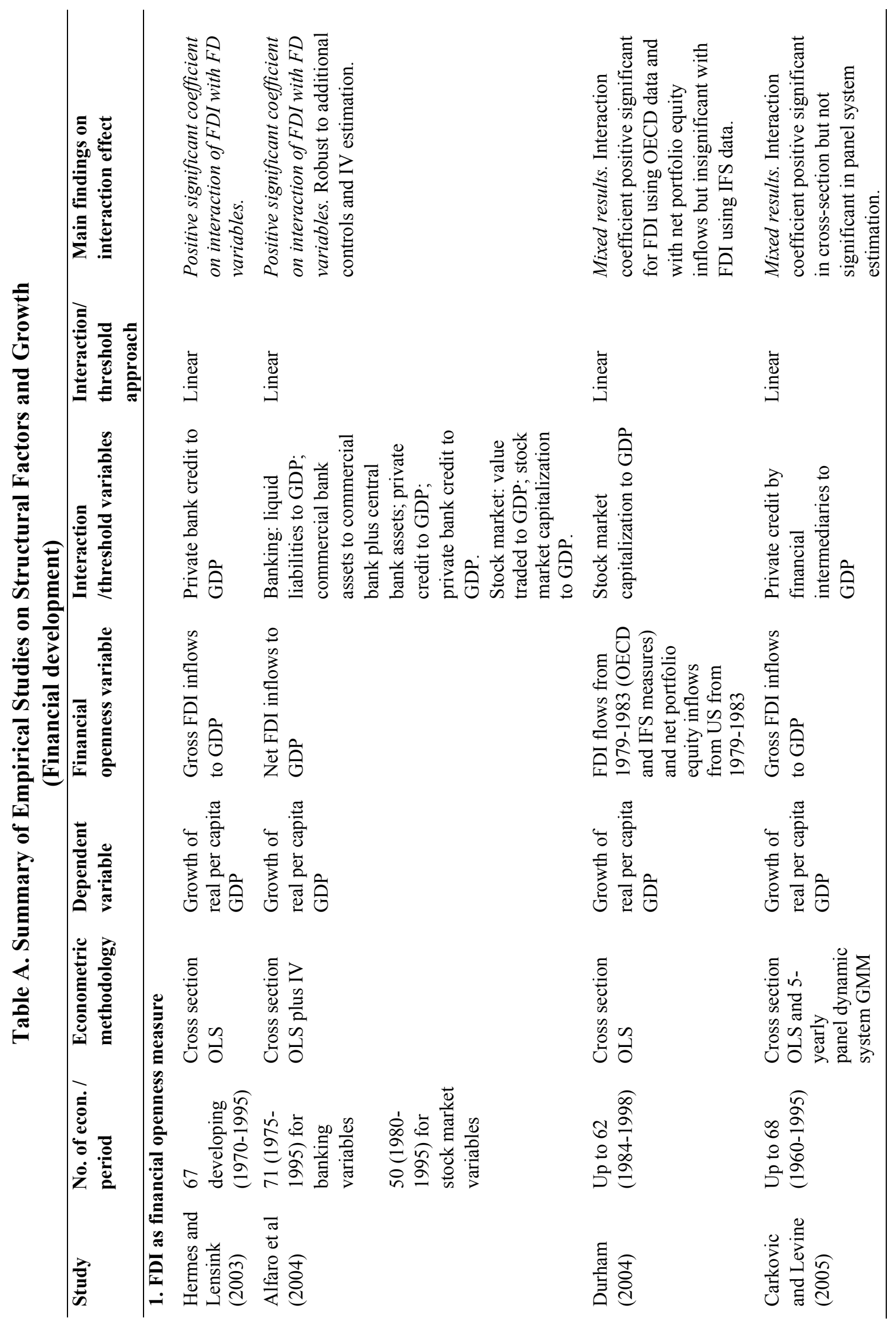




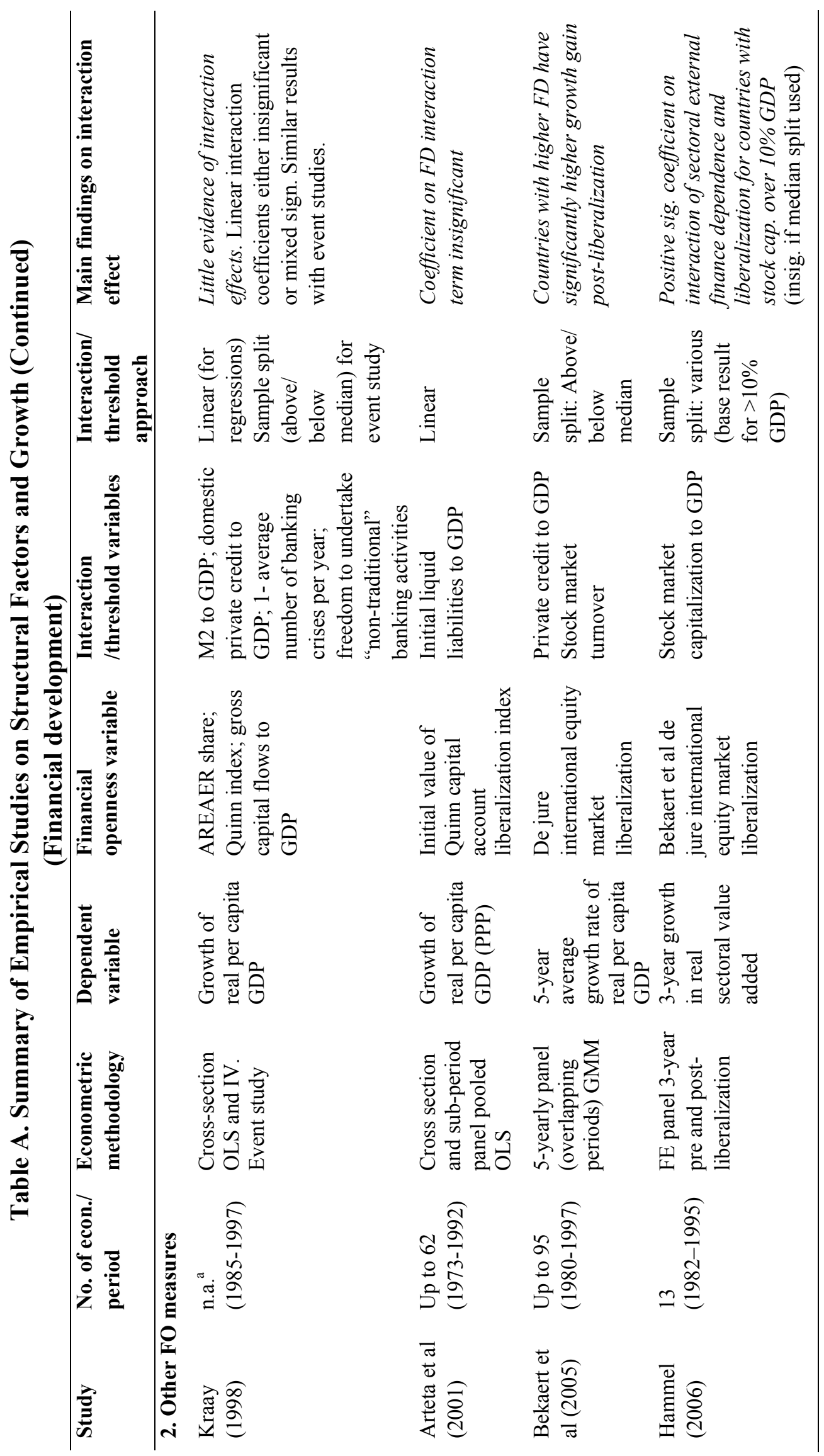




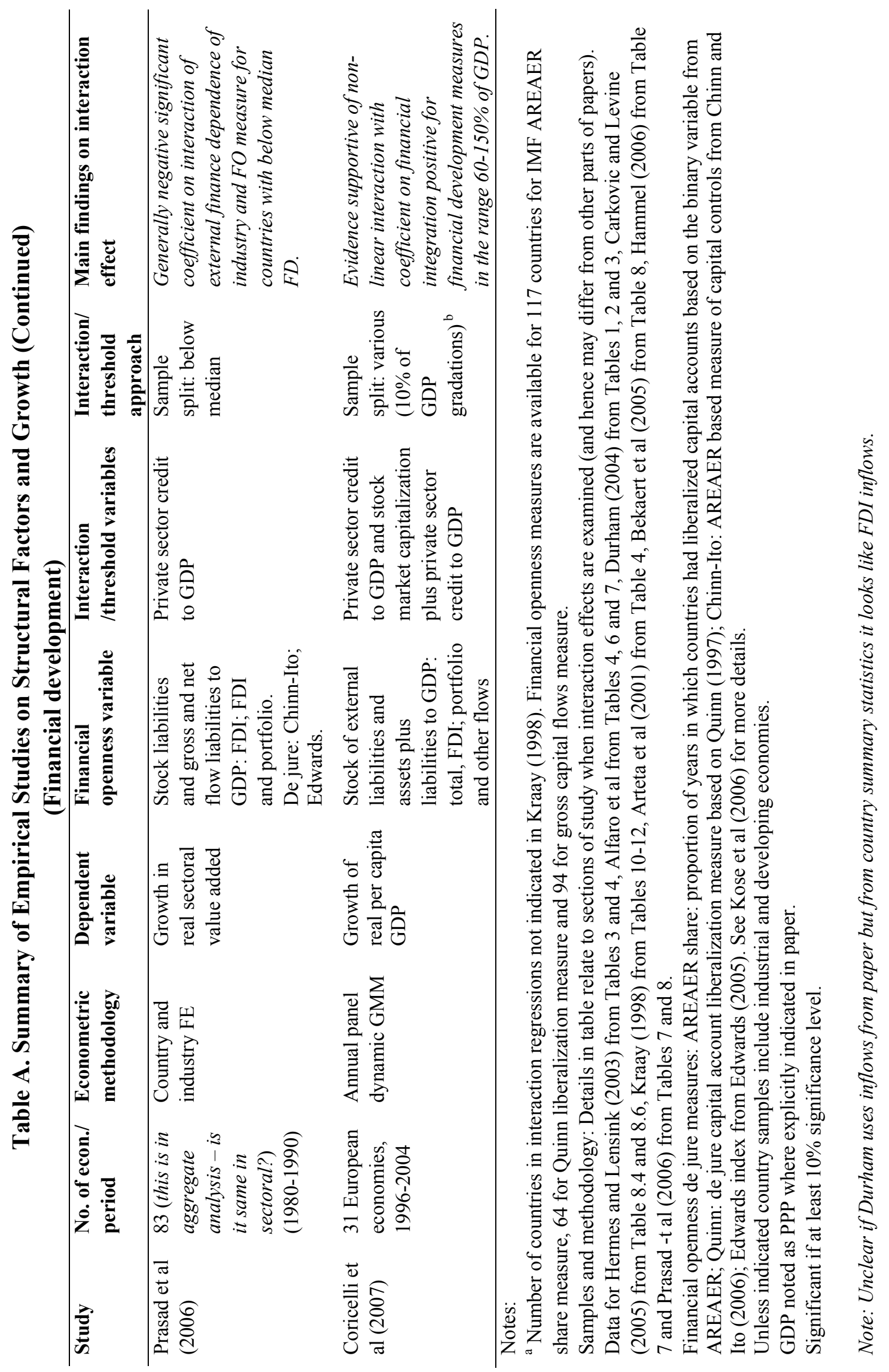




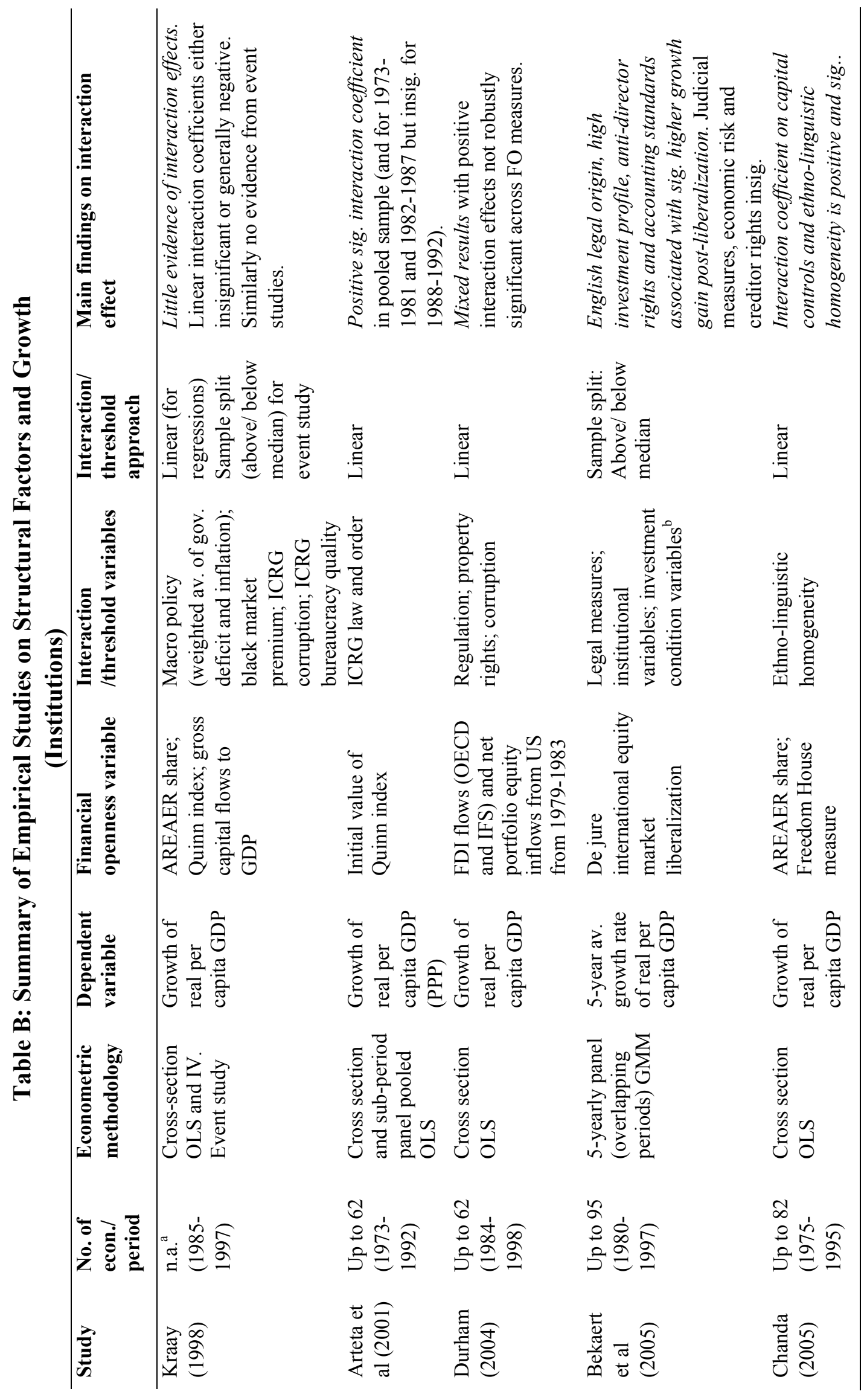




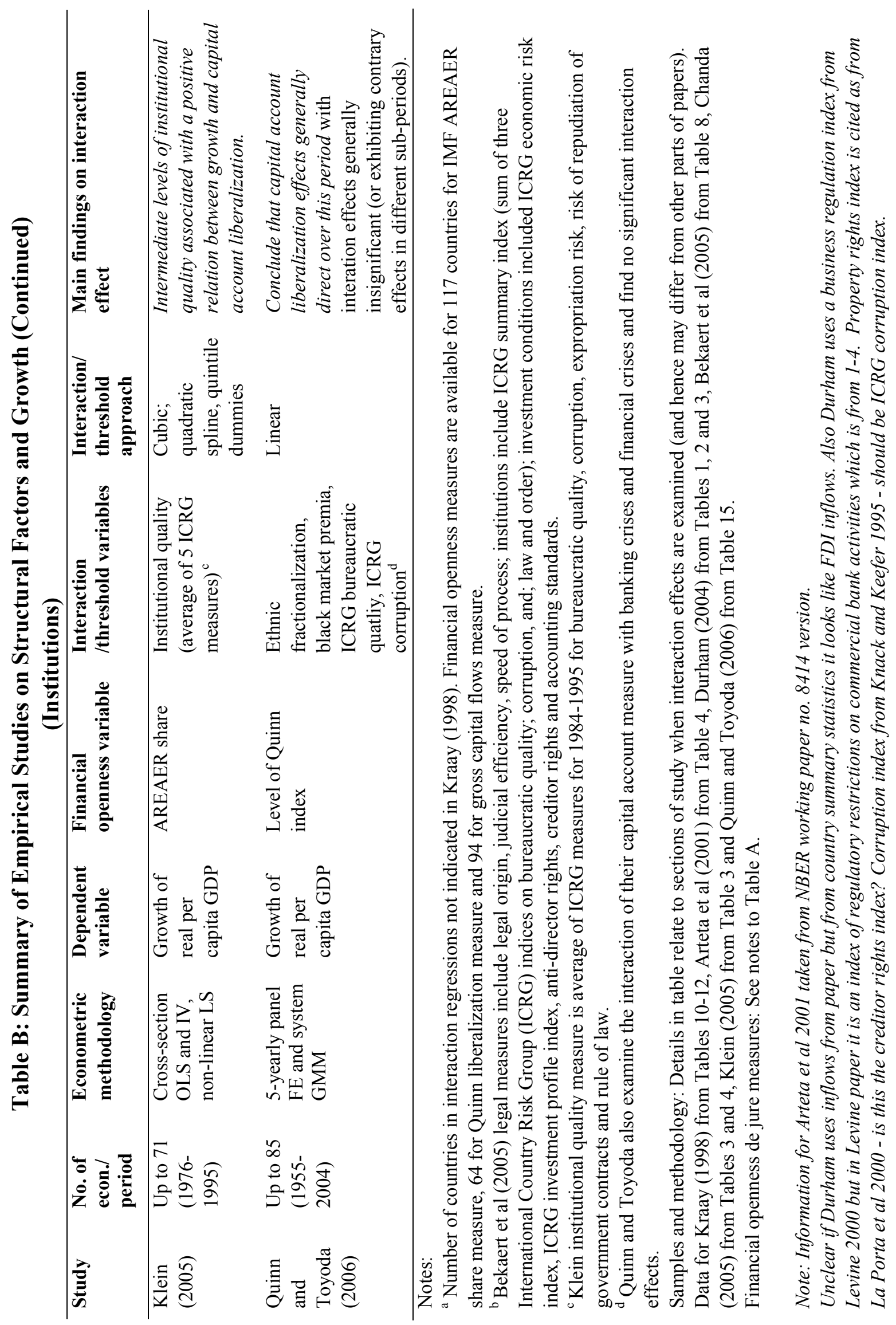




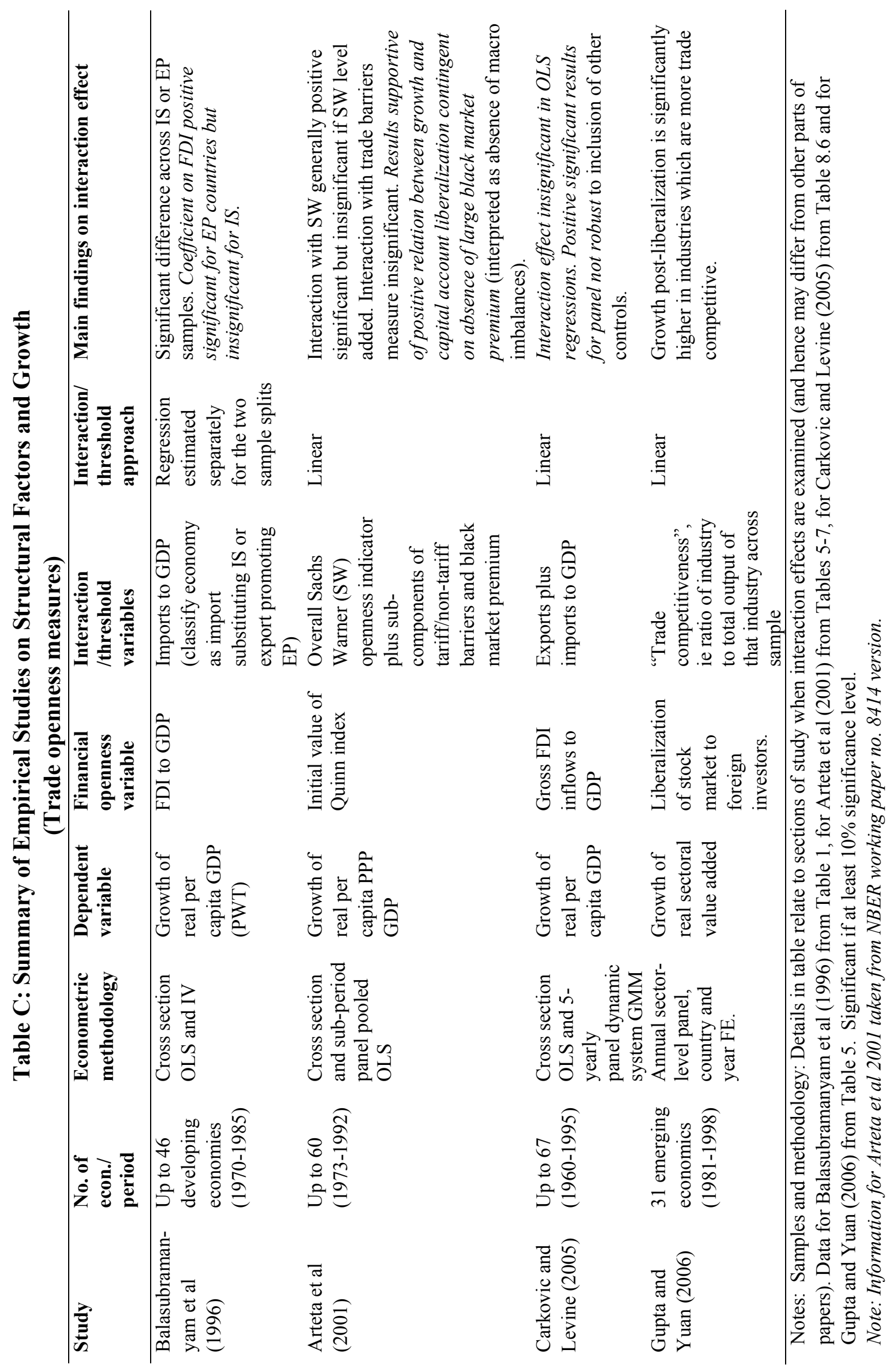

